\title{
Justicieae (Acanthaceae) do Semiárido do Estado da Bahia, Brasil
}

\author{
Ana Luiza Andrade Côrtes ${ }^{1,2,3}$ e Alessandro Rapini ${ }^{2}$
}

Recebido: 9.02.2011; aceito: 28.02.2013

\begin{abstract}
Justicieae (Acanthaceae) of the Semiarid of Bahia State, Brazil). The inventory and taxonomic study of the tribe Justicieae (Acanthaceae) of Bahia State's Semiarid region are presented. For the execution of this inventory, collections of Bahia herbaria and major herbaria of the Southeast and South of Brazil, and random collections (georeferenced) were conducted covering 25 municipalities of the Semiarid region of the Bahia State. Twenty-seven species and ten genera were recognized, namely: Justicia L. (17 species), Harpochilus Nees (2), Anisacanthus (A. trilobus Lindau), Clistax Mart. (C. speciosus Nees), Dicliptera Juss. (D. mucronifolia Nees), Herpetacanthus Nees (H. magnobracteolatus Idriunas \& Kameyama), Poikilacanthus Lindau (P. bahiensis (Nees) Wassh.), Pseuderanthemum Radlk. (P. modestum (Nees) Radlk.), Schaueria Nees (S. humuliflora Nees), and Thyrsacanthus Moric. (T. ramosissimus Moric.). A new combination is proposed, Justicia chamaedryoides (Nees) Wassh. ex A.L.A. Côrtes \& P.L.R. Moraes. Many of the species included in the treatment have not been described since the Flora Brasiliensis, published in the 19th century, and some are new reports to the Bahia State. Six species of Justicia, including four new species recently described besides Harpochilus neesianus and Anisacanthus trilobus, are endemic to the Semiarid. Key for identification and descriptions of taxa, illustrations and comments on the taxonomy and geographic distribution of species, including maps of occurrence in the State, are provided.
\end{abstract}

Key words: Caatinga, Floristics, Justicia, Taxonomy

RESUMO - (Justicieae (Acanthaceae) do Semiárido do Estado da Bahia, Brasil). Este trabalho consiste no levantamento florístico e estudo taxonômico da tribo Justicieae (Acanthaceae) no Semiárido do Estado da Bahia. Para a execução desse inventário, foram analisadas as coleções dos herbários baianos e dos principais herbários do Sudeste e Sul, e realizadas diversas coletas georeferenciadas e aleatórias abrangendo 25 municípios incluídos no Semiárido do Estado da Bahia. Foram reconhecidas 27 espécies e dez gêneros: Justicia L. (17 espécies), Harpochilus Nees (2), Anisacanthus (A. trilobus Lindau), Clistax Mart. (C. brasiliensis Nees), Dicliptera Juss. (D. mucronifolia Nees), Herpetacanthus Nees (H. magnobracteolatus Idriunas \& Kameyama), Poikilacanthus Lindau (P. bahiensis (Nees) Wassh.), Pseuderanthemum Radlk. (P. modestum (Nees) Radlk.), Schaueria Nees (S. humuliflora Nees) e Thyrsacanthus Moric. (T. ramosissimus Moric.). É proposta a nova combinação Justicia chamaedryoides (Nees) Wassh. ex A.L.A. Côrtes \& P.L.R. Moraes. Várias espécies não eram descritas desde a Flora Brasiliensis, publicada no século XIX, e algumas são ocorrências novas para o Estado da Bahia. Seis espécies de Justicia, incluindo quatro espécies recentemente descritas, além de Harpochilus neesianus e Anisacanthus trilobus, são endêmicas da Caatinga. Foram preparadas chaves de identificação e descrições dos táxons, além de ilustrações e comentários taxonômicos e sobre a distribuição geográfica das espécies, incluindo mapas de ocorrência no Estado.

Palavras-chave: Caatinga, Florística, Justicia, Taxonomia

\section{Introdução}

Acanthaceae compreende cerca de 250 gêneros e 3.200 espécies (Wasshausen 2004). Estão distribuídas no mundo todo, com centros de diversidade na região da Indo-Malásia, África (incluindo Madagascar), Brasil, Andes e América Central (Grant 1955, Wasshausen 2004). No Brasil, a família é representada por 41 gêneros e 432 espécies, destacando-se Justicia L., Ruellia L. e Aphelandra R. Br. (Profice et al. 2010).
Justicieae é uma das maiores tribos de Acanthaceae, sendo constituída por cerca de 100 gêneros e 2.000 espécies predominantemente tropicais (Scotland \& Vollesen 2000). Análises filogenéticas corroboram o monofiletismo da tribo (McDade \& Moody 1999, McDade et al. 2000a, b), que tem como principal sinapomorfia o grão de pólen tricolporado hexapseudocolpado. Quatro linhagens principais são reconhecidas nesse grupo, sendo a linhagem Pseuderanthemum grupo-irmão do restante da tribo. Outras relações genéricas ainda estão mal resolvidas

1. Parte da Dissertação de Mestrado da primeira Autora

2. Universidade Estadual de Feira de Santana, Departamento de Ciências Biológicas, Av. Transnordestina s/n, Novo Horizonte, 44036-900 Feira de Santana, BA, Brasil

3. Autor para correspondência: analuiza.cortes@gmail.com 
e novos esclarecimentos são necessários antes que se possa delimitar Justicia e seus gêneros afins com segurança (McDade et al. 2000a).

Muitas das espécies de Justicieae são utilizadas como ornamentais e algumas de Justicia também possuem importância forrageira e ecológica, sendo abundantes em florestas úmidas e dominantes em ambientes semiáridos (Ezcurra 2002). Estudos fitoquímicos com plantas do Semiárido têm revelado que algumas espécies dessa tribo também são promissoras do ponto de vista farmacológico, como Thyrsacanthus ramosissimus Moric. (Cabral et al. 2012).

No Brasil, a única obra tratando de todas as espécies brasileiras de Acanthaceae foi a Flora Brasiliensis (Nees 1847a), incluindo 343 espécies e 57 gêneros. Após esse tratamento, a delimitação de várias espécies foi modificada e boa parte dos gêneros sinonimizada. Dentre os estudos mais recentes abrangendo espécies brasileiras de Justicieae, destacam-se a Lista de Espécies da Flora do Brasil (Profice et al. 2010), a Flora de Santa Catarina (Wasshausen \& Smith 1969) e a Flora da Reserva Ducke (Kameyama 2006), no Amazonas. No Rio de Janeiro, podem ser citados os tratamentos para a APA Cairuçu (Profice 1997), em Parati, e para a Reserva Ecológica de Macaé de Cima (Profice 1998), em Nova Friburgo. Em Minas Gerais, destacam-se a Flora da Serra do Cipó (Kameyama 1995), a Flora da Reserva Florestal Mata do Paraíso (Braz et al. 2002) e a Flora de Grão Mogol (Kameyama 2003a).

No Estado da Bahia, os estudos florísticos e taxonômicos em Acanthaceae também são pontuais e estão predominantemente focados na Chapada Diamantina: Mucugê (Harley \& Simmons 1986), Pico das Almas (Harvey \& Wasshausen 1995) e Catolés (Kameyama 2003b); mas merecendo destaque também o inventário da Serra do Orobó (Cardoso \& Queiroz 2008) e dois levantamentos na Mata Atlântica: um na Serra do Teimoso (Amorim et al. 2005) e outro na Serra da Jiboia (Sobrinho \& Queiroz 2005). Para a região semiárida do Nordeste, por outro lado, o conhecimento sobre a diversidade da família está basicamente restrito a uma listagem obtida a partir do banco de dados de alguns herbários do Nordeste (Barbosa et al. 2006, Queiroz et al. 2006). Desta forma, o objetivo deste estudo foi ampliar o conhecimento sobre as Acanthaceae do Semiárido através do inventário de Justicieae do Semiárido, o qual também servirá de subsídio para flora de Acanthaceae do Estado.

\section{Material e métodos}

No Estado da Bahia, o Semiárido abrange cerca de $388.274 \mathrm{~km}^{2}$ (70\% do Estado) (Lobão et al. 2004). É caracterizado por clima quente e semiárido, com precipitação menor que $1.000 \mathrm{~mm} / \mathrm{ano}$, marcado por chuvas mal distribuídas ao longo do ano (Velloso et al. 2002). As Caatingas são dominantes cobrindo quase toda a extensão nordeste e central do Semiárido no Estado, praticamente circundando a Chapada Diamantina (Queiroz et al. 2006). Na porção meridional do Semiárido está entranhada a Chapada Diamantina, que oferece um mosaico vegetacional com a presença de cerrados e campos rupestres nos pontos altos; brejos e matas sazonais aparecem em encraves mais úmidos, geralmente associados a ambientes montanhosos que, em alguns casos, pode chegar a $1.500 \mathrm{~mm} / \mathrm{ano}$ (Queiroz et al. 2006).

As Caatingas representam o maior e o mais isolado núcleo de florestas sazonalmente secas da América do Sul, sendo um dos ecossistemas mais ameaçados do mundo (Queiroz 2006). Estudos como os de Giulietti et al. (2002) vêm desmistificando a antiga visão de que o Domínio Caatinga é pobre em biodiversidade e menos importante para a conservação. Na realidade, ele possui número relativamente alto de espécies, com uma parcela considerável dessa diversidade exclusiva, totalizando pelo menos 18 gêneros e 318 espécies endêmicas (Giulietti et al. 2002).

O presente estudo está baseado principalmente na análise das exsicatas das coleções depositadas nos herbários ALCB, CEPEC, HRB, HUEFS, MBM, RB, SP, SPF e UB. Foram realizadas excursões direcionadas a partir dos dados georreferenciados dos registros das exsicatas e também outras aleatórias, no período de maio de 2007 a abril de 2008, para coleta de representantes de Acanthaceae, priorizando espécies de Justicieae. As coletas abrangeram 25 municípios do Semiárido, e incluíram diversos ambientes, como Caatinga arbustivo-arbórea, campos rupestres e florestas estacionais. Uma exsicata de cada material coletado encontra-se depositado no Herbário da Universidade Estadual de Feira de Santana (HUEFS) e duplicatas foram distribuídas para outros herbários.

A classificação adotada para Justicieae segue Bremekamp (1965). A terminologia aplicada para morfologia das folhas, brácteas e bractéolas está baseada em Hickey (1973). A nomenclatura empregada para a testa das sementes e para as inflorescências está fundamentada na utilizada por Graham (1988) para Justicia, tendo sido adaptada para os demais gêneros 
da tribo e para a disposição das tecas, prevalecendo o uso de tecas paralelas, oblíquas e superpostas (com conectivo ca. $1 \mathrm{~mm}$ compr.). A descrição dos tipos de corola, formas de estruturas sólidas e indumento seguem Radford et al. (1974). Os dados de distribuição geográfica, hábitats, fenologia e nomes populares foram obtidos das etiquetas de herbário e da literatura. A delimitação do Semiárido corresponde à área cinza nos mapas de distribuição das espécies, seguindo Velloso et al. (2002). Os táxons estão ordenados alfabeticamente.

\section{Resultados e Discussão}

\section{Acanthaceae Juss.}

Ervas, subarbustos, arbustos ou trepadeiras. Folhas simples, quase sempre opostas, decussadas, geralmente com cistólitos, sem estípulas. Inflorescências racemosas, cimosas, espigas, tirsos, panículas ou flores solitárias, geralmente com 1 bráctea e 2 bractéolas por flor, foliáceas ou petaloides, às vezes encobrindo o tubo da corola. Flores monoclinas, zigomorfas. Cálice com 3-5 lacínias livres ou concrescidas entre si. Corola gamopétala, bilabiada, infundibuliforme, campanulada, hipocrateriforme ou tubular. Androceu com 2 ou 4 estames epipétalos, geralmente didínamos, às vezes unidos 2 a 2, anteras 1- ou 2-tecas, com ou sem apêndice, e até 2 estaminódios presentes. Gineceu com ovário súpero, 2-locular, geralmente 2-13 óvulos por lóculo, superpostos em fileira única, ou 2 óvulos colaterais, em placentação axilar, estilete filiforme e estigma geralmente 2-lobado; disco nectarífero anular ou cupular na base do ovário. Cápsulas 2-valvadas loculicidas, comumente estipitadas, com a porção basal estéril sólida e deiscência explosiva, providas de funículos em forma de gancho (retináculo) persistentes; sementes 2 a muitas, orbiculares, geralmente planas.

\section{Justicieae}

Ervas a arbustos. Folhas com margens geralmente inteiras a raramente crenadas (Herpetacanthus Nees) ou dentadas (Pseuderanthemum Radlk.). Cálice com 3-5 lacínias concrescidas entre si. Corola com prefloração imbricada ascendente, bilabiada, tubular ou hipocrateriforme. Androceu geralmente com 4 estames ou 2 estames e 2 estaminódios às vezes presentes, tecas paralelas, oblíquas ou superpostas; 4 tipos polínicos sensu Lindau (1895): grãos de pólen 3-colporados e 6-colpados (Spangenpollen); 3-colporados e 6-sincolpados (Rhamenpollen); 2-3-colporados e 4-6-sincolpados com até quatro fileiras de aréolas margeando os cólporos (Knötchenpollen) e grãos de pólen lenticulares ou elipsoidais, 2-porados com um cinturão de espinhos na borda das aberturas (Gürtelpollen). Gineceu com ovário 2-4-ovulado. Cápsulas com 2-4 sementes.

Na região semiárida da Bahia, a tribo está representada por 27 espécies e dez gêneros. Algumas delas são restritas ao Semiárido baiano: Herpetacanthus magnobracteolatus Idriunas \& Kameyama, J. angustissima A. Côrtes \& Rapini, Justicia attenuata A. Côrtes \& Rapini, J. chlamidocalyx A. Côrtes \& Rapini, J. harleyi Wassh., J. jacuipensis A. Côrtes \& Rapini e J. lepida (Moric.) Wassh. Muitas são endêmicas do Estado ocorrendo tanto em vegetação de Caatinga como na Mata Atlântica: J. cuneifolia Nees \& Mart., J. chamaedryoides (Nees) Wass. ex A. Côrtes \& P.L.R. Moraes, Poikilacanthus bahiensis (Nees) Wassh., Pseuderanthemum modestum (Nees) Radlk. e Schaueria humuliflora Nees. Ao passo que Anisacanthus trilobus Lindau, Harpochilus neesianus Mart. ex Nees, Justicia xipotensis (Roem. \& Schult.) A. Côrtes \& Rapini e T. ramosissimus estendem a outros Estados nordestinos. Outras espécies são amplamente distribuídas no Brasil e América do Sul: Dicliptera mucronifolia Nees, Justicia aequilabris (Nees) Lindau, J. comata (L.) Lam., J. congrua Nees, $J$. glaziovii Lindau e $J$. laevilinguis (Nees) Lindau. Harpochilus phaeocarpus Nees está identificada para o Semiárido da Bahia, mas só tem registro atual para regiões de Mata Atlântica. Ainda, espécies que não haviam sido encontradas no Estado também foram registradas, como Clistax speciosus Nees, Justicia asclepiadea (Nees) Wassh. \& C. Ezcurra, J. simonisia V.A.W. Graham e J. thunbergioides (Lindau) Leonard.

Chave de identificação para os gêneros de Justicieae do Semiárido do Estado da Bahia

1. Corola não bilabiada; estames inclusos com anteras bitecas; 2 estaminódios presentes Pseuderanthemum

1. Corola bilabiada; estames exsertos ou, se inclusos, com 2 estames com anteras monotecas, estaminódios ausentes 
2. Caules hexangulares; inflorescência em fascículos; flores subtendidas por 4 brácteas:

2 brácteas lineares ou lanceoladas e 2 largamente ovadas a elípticas; flor ressupinada Dicliptera

2. Caules subquadrangulares ou cilíndricos; inflorescência em espigas ou tirsos; flores subtendidas por 1 bráctea espatulada, largamente ovada, lanceolada, linear ou oblanceolada; flor não ressupinada

3. Brácteas largamente espatuladas ou obovadas, ciliadas com tricomas glandulares, principalmente na porção superior; disco nectarífero cupular, tetralobado Poikilacanthus

3. Brácteas largamente ovadas, triangulares, oblanceoladas, lanceoladas a lineares (quando espatuladas, não ciliada), ciliadas ou não com tricomas eglandulares; disco nectarífero anular, cupular, eventualmente bilobado

4. Estames 4, didínamos; anteras 2 bitecas e 2 monotecas Herpetacanthus

4. Estames 2, isodínamos; anteras 2 bitecas

5. Tecas paralelas; brácteas largamente ovadas ou lanceoladas a oblanceoladas, mais de $1 \mathrm{~mm}$ larg.

6. Brácteas petaloides, largamente ovadas (ca. $10 \mathrm{~mm}$ larg.); cálice com 5 lacínias Schaueria

6. Brácteas foliáceas, lanceoladas a lineares ou oblanceoladas (até $5 \mathrm{~mm}$ larg.); cálice com 3-5 lacínias

7. Ramos subquadrangulares a quadrangulares; brácteas lineares a oblanceoladas; corola esverdeada a creme Harpochilus

7. Ramos subcilíndricos a cilíndricos ou heptagonais; brácteas lanceoladas a lineares; corola vermelha.

8. Ramos cilíndricos, com estrias inconspícuas; cálice ca. 5,3 mm compr., com 5 lacínias iguais; sementes orbiculares, tuberculadas, borda gloquidiada Thyrsacanthus

8. Ramos heptagonais, com estrias bem marcadas; cálice mais que $7 \mathrm{~mm}$ compr., com 3 lacínias desiguais; sementes cordiformes, lisas, borda inteira Anisacanthus

5. Tecas oblíquas a superpostas, quando paralelas as brácteas são estreitamente triangulares a lineares com até $0,8 \mathrm{~mm}$ larg.

9. Cálice cupular, menor que $1 \mathrm{~mm}$ compr. Clistax

9. Cálice com 4 ou 5 lacínias, lanceoladas a triangulares, mais que $1 \mathrm{~mm}$ compr. Justicia

1. Anisacanthus Nees, Linnaea 16: 307. 1842.

Arbustos ramificados; ramos cilíndricos ou heptagonais. Folhas pecioladas ou sésseis. Inflorescência em espiga, racemo, tirso ou paniculada, axilar ou terminal, com 1 a várias flores por nó, secundas ou opostas; 1 bráctea e 2 bractéolas inconspícuas. Cálice geralmente com 5 ou 3 lacínias (A. trilobus) desiguais. Corola geralmente vermelha, bilabiada a quadrífida, não ressupinada; lábio superior geralmente inteiro ou levemente bilobado no ápice; lábio inferior trilobado com lobos recurvados, estreitos. Androceu com 2 estames exsertos, anteras bitecas, tecas paralelas ou levemente oblíquas, múticas, glabras, estaminódios ausentes. Cápsulas obovadas, estipitadas, sementes 2 ou 4.

Anisacanthus é reconhecido geralmente por reunir plantas arbustivas bem ramificadas, com flores de corola vermelha e quadrífida. Inclui 13 espécies, praticamente restritas a regiões áridas e semiáridas das Américas do Norte e Central, com exceção de A. trilobus e $A$. pohlii Lindau ocorrentes na América do Sul. Estudos filogenéticos com dados moleculares (Daniel et al. 2008) revelaram que as espécies das Américas do Norte e Central divergiram independentemente das espécies sul-americanas. As espécies da América do Sul foram, então, transferidas para o gênero Thyrsacanthus (Côrtes et al. 2010), exceto A. trilobus e $A$. pohlii que apresentaram o tipo polínico de Justicia e espécies afins, e falta de informações, respectivamente.

1.1. Anisacanthus trilobus Lindau, Notizbl. Königl.

Bot. Gart. Berlin 56(6): 196. 1914.

Nome comum: colherzinha (PI), sarandi-de-tatu (in sched.).

Figuras $1 \mathrm{a}-\mathrm{k}, 2,17 \mathrm{a}$

Arbusto 1,5-2 m alt.; ramos heptagonais com estrias bem marcadas, conspícuas e pubescentes. Pecíolo 2-5 mm compr.; lâmina 2-6,5 × 0,5-2,4 cm, estreitamente elíptica a elíptica ou oblonga, glabra a esparsamente híspida, mais densa nas nervuras, ciliada, 


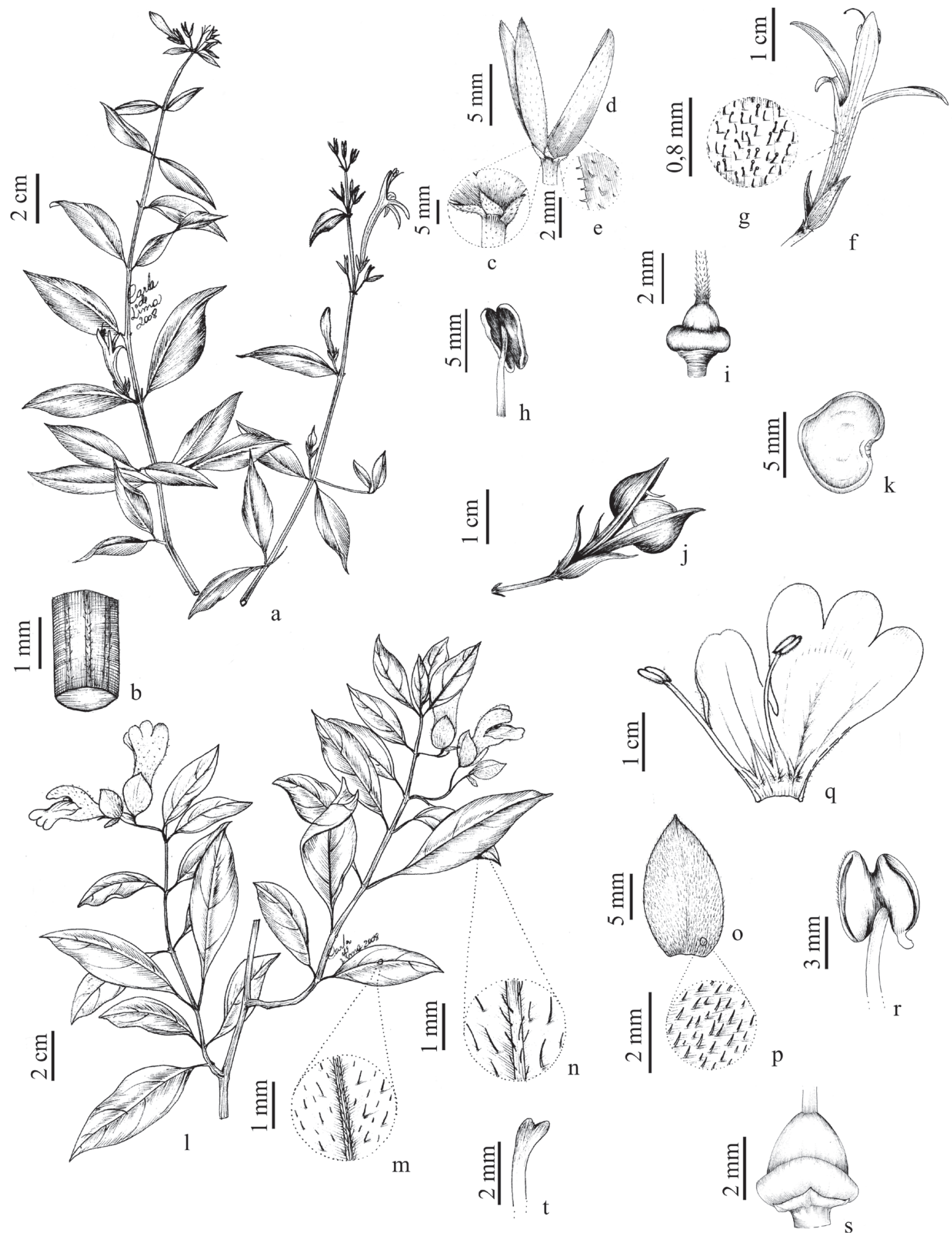

Figura 1. a-k. Anisacanthus trilobus. a. Ramo florido. b. Detalhe do caule. c. Bractéolas. d. Cálice. e. Detalhe do indumento do cálice. f. Flor. g. Detalhe do indumento da corola. h. Antera. i. Disco nectarífero, ovário e base do estilete. j. Cálice, fruto com semente. k. Semente. 1-t. Clistax speciosus. 1. Ramo florido. m. Detalhe do indumento da face adaxial da folha. $\mathrm{n}$. Detalhe do indumento da face abaxial da folha. o. Bractéola, face abaxial. p. Detalhe do indumento da face abaxial da bractéola. q. Corola evidenciando os estames. r. Estame. s. Cálice, disco nectarífero e ovário. t. Estigma. (a-i. Leite 187; j-k. Conceição 2310; 1-n. Ganev 397; o-t. Queiroz 12883).

Figure 1. a-k. Anisacanthus trilobus. a. Flowering branch. b. Stem detail. c. Bracteoles. d. Calyx. e. Calyx indumentum detail. f. Flower. g. Detail of corolla indumentum. h. Anther. i. Nectariferous disk, ovary and base of the style. j. Calyx, fruit with seed. k. Seed. 1-t. Clistax speciosus. 1. Flowering branch. m. Adaxial leaf surface indumentum detail. n. Adaxial leaf surface indumentum detail. o. Bracteole, abaxial surface. p. Indumentum detail of abaxial bracteole surface. q. Corolla showing the stamens. r. Anther. s. Calyx, nectariferous disk and ovary. t. Stigma. (a-i. Leite 187; j-k. Conceição 2310; 1-n. Ganev 397; o-t. Queiroz 12883). 
ápice obtuso a atenuado, base cuneada a decorrente. Inflorescência em tirsos, dicásios pedunculados 0,5-1 cm compr.; brácteas ca. $5 \times 1,5 \mathrm{~mm}$, lanceoladas, estrigosas em ambas as faces, híspidas nas nervuras; bractéolas $0,3-2 \times$ ca. $0,2 \mathrm{~mm}$, lineares, esparsamente pubescentes a híspidas. Cálice 0,8-1,1 cm compr., lacínias 3, lanceoladas, esparsamente pubérulas a híspidas em ambas as faces, desiguais, as menores $6-10 \times 1-2 \mathrm{~mm}$, a maior $8-10 \times 2-4 \mathrm{~mm}$, esta frequentemente trilobada no ápice. Corola vermelha, 3-4 cm compr., bilabiada, internamente estrigosa nas nervuras abaixo dos filetes, no restante glabra, externamente pubescente, com tricomas glandulares, tubo 1,2-2,2 cm compr., ereto, lábio superior $1,4-2,4 \mathrm{~cm} \times 3-5 \mathrm{~mm}$, bilobado no ápice, lábio inferior 1,7-2 cm $\times 1-2 \mathrm{~mm}$. Filetes ca. 1,3 cm compr., anteras 4-6 mm compr., tecas paralelas. Estilete $3,2-3,5 \mathrm{~cm}$ compr., pubescente na metade basal; disco nectarífero anular. Cápsula 2-2,5 cm compr., glabra, com porção fértil obovóide; sementes 4 , ca. $8 \mathrm{~mm}$ diâm., cordiformes, lisas, borda inteira.

Material selecionado: BRASIL. BAHIA: Barra, $10^{\circ} 33^{\prime} \mathrm{S}$ 43ํํ' 'W, 6-IV-1978, fl., J.S. Assis 152 (HRB); Bela Vista, estrada Delfino a Sento Sé, Morro dos Cactos, 10³9'S 39 44'W, 25-III-2004, fl., bot., M.V. Moraes 657 (HUEFS); Caetité, BA-430 para Igaporã, $13^{\circ} 47^{\prime} 25,2^{\prime \prime S} 42^{\circ} 39^{\prime} 48,4 " \mathrm{~W}, 943$ m s.n.m., 22-IV-2008, fl., A.L.A. Côrtes et al. 95 (HUEFS); Campo Formoso, $10^{\circ} 28^{\prime} \mathrm{S} 41^{\circ} 14^{\prime} \mathrm{W}, 29-\mathrm{IV}-1981$, bot., R.P. Orlandi 372 (HRB, HUEFS); Delfino, estrada para Mimoso de Minas, $20 \mathrm{~km}$ de Delfino, 10²9'31"S 4120'35"W, 826 m s.n.m., 7-III-1997, fl., fr., bot., P. Gasson 6115 (ALCB, HRB, HUEFS); Formosa do Rio Preto, estrada para Barreiras, $11^{\circ} 08^{\prime} 38,8^{\prime \prime} \mathrm{S}$ 4504'39,6"W, 527 m s.n.m., 24-IV-2008, fl., A.L.A. Côrtes et al. 104 (HUEFS); Igaporã, estrada para Tanque Novo, 9,2 km após o trevo, $13^{\circ} 43^{\prime} 50,1$ "S 42³6'29,4"W, 902 m s.n.m., 22-IV-2008, fl., A.L.A. Côrtes et al. 97 (HUEFS); Macaúbas, Canatiba, 130'ㅇ 4249'W, 14-III-1981, fl., S.B. Silva 211 (CEPEC, HRB); Morpará, baixada sujeito a inundação,

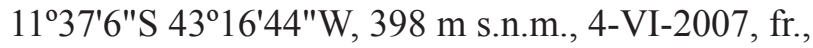
A.A. Conceição 2310 (HUEFS); Sento Sé, Minas do Mimoso-Cascaeira, $10^{\circ} 16^{\prime} 52^{\prime \prime S} 41^{\circ} 23^{\prime} 24^{\prime \prime} \mathrm{W}$, 886 m s.n.m., 1-IV-2002, fl., fr., bot., K.R.B. Leite 187 (HUEFS).

Material adicional examinado: BRASIL. PIAUí: Serra Branca, II-1907, E. Ule 7480 (holótipo B n.v. - foto $\mathrm{K}$ !, F!); Bocaína, Curral Velho, próximo à barragem, 24-IV-2002, fl., bot., R. Barros s.n. (HUEFS 67187,
TEGB 17555); Padre Marcos, Serra Velha, Km 2 da estrada vicinal para Alagoinha do Piauí, 420 m s.n.m., 21-V-1995, fl., fr., bot., M.E. Alencar 264 (HUEFS). CEará: Crateús, Croatá perto das Cruzinhas, Serra das Almas, 0508'39"S 4055'29"W, 650 m s.n.m., s.d., fl., bot., F.S. Araújo 1593 (HUEFS).

Anisacanthus trilobus, arbusto extremamente ramificado, caracteriza-se principalmente pelas 3 lacínias do cálice tripartidas, de tamanhos desiguais, frequentemente a maior trilobada no ápice, e corola vermelha com os lobos recurvos. Diferencia-se Thyrsacanthus ramosissimus pela cápsula grande 2-2,5 cm compr. (vs. 1-1,6 cm compr.), sementes lisas e borda inteira ( $v s$. sementes tuberculada e borda gloquidiada) e as características polínicas serem muito diferentes do comumente encontrado entre as espécies de Thyrsacanthus e da "linhagem Tetramerium" (Daniel et al. 2008, Côrtes et al. 2010). É endêmica da região semiárida do Nordeste, ocorrendo geralmente na Caatinga, sobre solos arenosos avermelhados, dos Estados Piauí, Ceará, Pernambuco e Bahia. Floresce e frutifica entre janeiro e julho, sendo suas flores frequentemente visitadas por Trigona sp. Essa abelha geralmente faz um corte na base do tubo da corola e pilha néctar; Apis sp. aproveita-se dessa abertura para também conseguir néctar dessas flores.

\section{Clistax Mart., Nov. Gen. Sp. Pl. 3: 26.1829.}

Arbustos; ramos cilíndricos. Folhas geralmente pecioladas. Inflorescências em tirso axilar com 1-2 flores por nó; 1 bráctea inconspícua e 2 bractéolas ovadas, coalescentes na base, envolvendo o perianto. Cálice cupular, breve, inteiro ou sinuoso a dentado no ápice. Corola alva a lilás, bilabiada, não ressupinada; lábio superior bilobado no ápice, lábio inferior trilobado, com lobos amplos. Androceu com 2 estames exsertos, anteras bitecas, tecas oblíquas, apêndice basal, pubérulas a glabras, estaminódios ausentes. Cápsulas obovadas, estipitadas, sementes 4 .

$\mathrm{O}$ gênero distingue-se dos demais da tribo pelas duas bractéolas grandes e coalescentes na base, cobrindo parte da corola, e pelo cálice cupular. Inclui duas espécies, $C$. speciosus e $C$. brasiliensis Mart., exclusivamente brasileiras. Nees (1847a) incluiu Clistax na tribo Thunbergieae por causa das sementes, sustentadas por um retináculo cuculado e porque, como em Mendoncia Vell. ex Vand., ele também é caracterizado por um cálice cupuliforme e bractéolas grandes e ovadas. Bentham (1876), Lindau (1895) e Scotland \& Vollesen (2000), no entanto, 
basearam-se na corola bilabiada e nos dois estames com anteras bitecas para classificarem o gênero em Justicieae. Estudos filogenéticos (McDade, dados não publicados) vêm corroborando sua posição nesta última tribo, relacionando Clistax a Harpochilus Nees.

2.1. Clistax speciosus Mart. in Martius, Fl. Bras. 9: 14. 1847.

Figuras 11 -t, 2

Arbusto escandente, 0,6-2 m alt.; ramos subcilíndricos a cilíndricos, com 6 estrias longitudinais, pilosos a vilosos principalmente nas estrias. Pecíolo 0,6-2 cm compr.; lâmina 4,5-7,5 × 1,5-4 cm, elíptica a ovada, pilosa, às vezes com tricomas esparsos na face adaxial, ápice aguda, base cuneada a decorrente. Inflorescência em tirsos, pedunculadas $1-1,2 \mathrm{~cm}$ compr.; brácteas 5-15 × 2-5 mm, oblanceoladas, pubescentes a pilosas; bractéolas 1,3-2 × 1-1,3 cm, amplamente ovadas, concrescidas na base, glabras a pubescentes ou pilosas; pedicelo até $1 \mathrm{~mm}$ compr. Cálice cupular, inconspícuo, menor que $1 \mathrm{~mm}$ compr., glabro a pubérulo no ápice. Corola lilás, ca. $3,5 \mathrm{~cm}$ compr., externamente com tricomas glandulares, internamente glabra, com 3 tufos de tricomas no tubo, próximo ao ovário; tubo ca. $1,5 \mathrm{~cm}$ compr., ereto, lábio superior 1,5-2 $\times 1,5 \mathrm{~cm}$, bilobado no ápice, lábio inferior 2,2-2,5 $\times 0,8-1 \mathrm{~cm}$. Filetes 1,5-2 cm compr.,

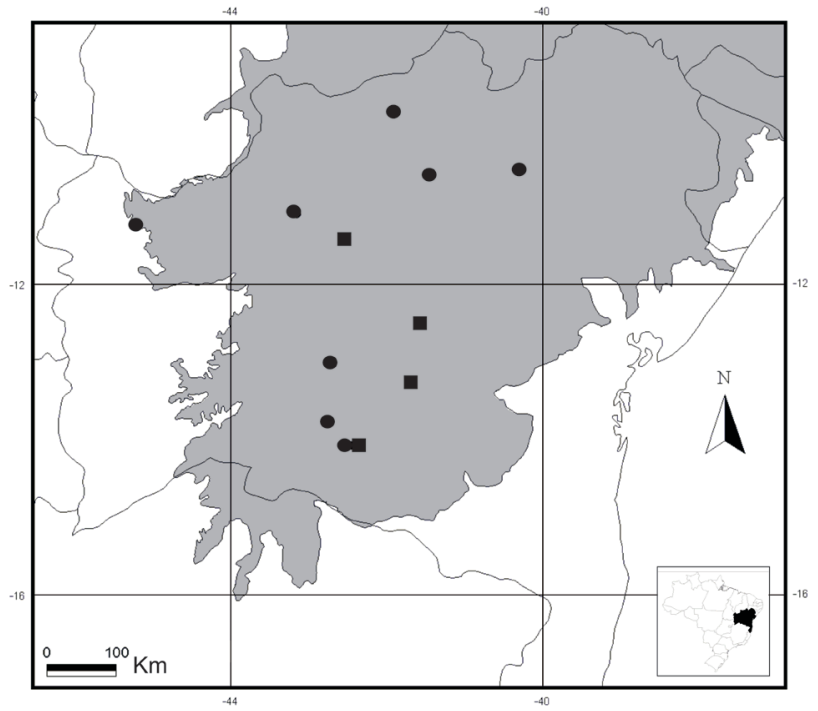

Figura 2. Distribuição de Anisacanthus trilobus (๑) e Clistax brasiliensis (ם) no Semiárido do Estado da Bahia, Brasil (área cinza).

Figure 2. Distribution of Anisacanthus trilobus (-) and Clistax brasiliensis ( $\mathbf{\square})$ in the Semiarid of Bahia State, Brazil (gray area). anteras 4-5 mm compr., tecas oblíquas, tecas superiores pubérulas no dorso. Estilete ca. $2,5 \mathrm{~cm}$ compr., pubescente; disco nectarífero anular. Cápsula ca. $2 \mathrm{~cm}$ compr., glabra, com porção fértil obovoide; sementes ca. 5 mm diâm., suborbiculares, lisas, borda inteira.

Material selecionado: BRASIL. BAHIA: Abaíra, estrada Engenho-Marques ca. $9 \mathrm{~km}$ de Catolés, $13^{\circ} 22^{\prime} \mathrm{S} 41^{\circ} 48^{\prime} \mathrm{W}, 1.100 \mathrm{~m}$ s.n.m., 10-IV-1992, fl., W. Ganev 397 (HUEFS); Caetité, Caraíbas, 1359'36"S $42^{\circ} 25^{\prime} 55^{\prime \prime} \mathrm{W}, 850$ m s.n.m., 13-III-2002, fl., bot., H.P. Bautista et al. 3225 (HRB, HUEFS); Gentio de Ouro, estrada Gentio do Ouro a Brotas de Macaúbas, $11^{\circ} 27^{\prime} 54^{\prime \prime S} 42^{\circ} 31^{\prime} 38^{\prime \prime} \mathrm{W}, 1.139$ m s.n.m., 17-V-2002, fl., fr., E.R. Souza et al. 289 (HUEFS); Palmeiras, caminho para Conceição dos Gados, 12²31'59"S 41'33'11"W, 21-III-2003, bot., E. Melo et al. 3539 (HUEFS).

Material examinado adicional: BRASIL. BAHIA: Vitória da Conquista, ca. $5 \mathrm{~km} \mathrm{~N}$ de Vitória da Conquista em ramal para José Gonçalves a partir

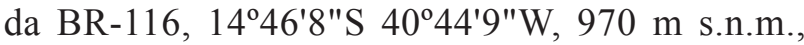
12-IV-2007, fl., fr., L.P. Queiroz et al. 12883 (HUEFS).

Clistax speciosus é reconhecida pelos tirsos axilares, as bractéolas ovadas, coalescentes na base, pubescentes, cálice cupuliforme e membranáceo, corola ca. 3,5 cm compr., com lábios amplos e uma estria branca no lobo central do lábio inferior. Segundo Nees (1847a), C. speciosus diferencia-se de C. brasiliensis por possuir folhas elípticas a ovadas (vs. oblongo-lanceoladas), bractéolas glabras, pubescentes a pilosas (vs. glabras). Ocorre nos Estados de Minas Gerais e Bahia, geralmente em florestas estacionais. Floresce principalmente de março a julho, iniciando a frutificação em maio.

3. Dicliptera Juss., Ann. Mus. Natl. Hist. Nat. 9: 267. 1807.

Ervas a arbustos; ramos hexangulares. Folhas geralmente pecioladas. Inflorescência em espigas, cimas, fascículos, umbelas ou paniculadas, axilar ou terminal, com 1 a várias flores por nó, subtendidas por 2 brácteas menores, 2 geralmente ovadas e 2 bractéolas inconspícuas. Cálice com 5 lacínias, iguais. Corola rosa, vermelha, laranja ou branca, bilabiada, geralmente ressupinada; lábio superior ereto a côncavo, tridentado no ápice; lábio inferior estreito. Androceu com 2 estames exsertos; anteras bitecas, tecas oblíquas, geralmente desiguais, uma 
das maiores às vezes apendiculada na base, glabras, estaminódios ausentes. Cápsulas obovadas ou orbiculares, curtamente estipitadas; sementes 2 ou 4.

Dicliptera é normalmente reconhecido pelo caule hexagonal, pelas cimas bracteadas e pela flor comumente ressupinada. Conta com 80 a 150 espécies tropicais ou subtropicais (Wasshausen \& Wood 2003) e está incluído no clado Diclipterinae, grupo-irmão das "Justicioides" do Novo Mundo. Uma característica que o distingue dos demais gêneros da tribo (exceto de Rungia Nees e Metarungia Baden) é o fruto com deiscência elástica da placenta (Daniel 1986, McDade et al. 2000a).

\subsection{Dicliptera mucronifolia Nees in Martius, Fl.}

\section{Bras. 9: 161. 1847.}

Nome comum: melosa, melosa-de-boi (CE, in sched.). Figuras $3 \mathrm{a}-\mathrm{i}, 5,17 \mathrm{~b}$

Arbusto, ca. 50-80 cm alt.; ramos pubescentes nas estrias, com tricomas glandulares. Pecíolo 1,5-4 cm compr.; lâmina 4-10 × 2-4 cm, elíptica, ápice atenuado, esparsamente pubescente principalmente quando jovem, tricomas mais longos nas nervuras, base cuneada a brevemente decorrente. Inflorescência em fascículos com 3-5-flores, sésseis; brácteas 4, verde-esbranquiçadas: 2 na base de cada cima, ca. $5 \times 0,5 \mathrm{~mm}$, lineares a lanceoladas, glabras ou com tricomas somente na nervura abaxial, as outras 2 subtendendo 2 ou 3 flores, desiguais, a maior $0,8-1,2 \times 0,5-1 \mathrm{~cm}$, a menor 7-11 $\times 3-6 \mathrm{~mm}$, amplamente ovadas a elípticas, esparsamente hirtelas em ambas as faces e com tricomas glandulares, ciliadas com tricomas 1-1,5 mm compr.; bractéolas 3-4 $\times$ ca. 0,4 mm, lanceoladas, hirtelas, com tricomas glandulares. Cálice 2-2,2 mm compr., lacínias $1-1,2 \times$ ca. $0,5 \mathrm{~mm}$, lanceoladas, hirtelas, com tricomas glandulares. Corola rosa a lilás, ressupinada, 1,1-2,5 cm compr., internamente glabra, externamente pilosa e com poucos tricomas glandulares, tubo ca. $8 \mathrm{~mm}$ compr., ereto, lábio superior ca. $8 \times 3 \mathrm{~mm}$, inteiro no ápice, lábio inferior branco com máculas lilás, ca. $8 \times 2 \mathrm{~mm}$. Filetes ca. $8 \mathrm{~mm}$ compr., anteras ca. $1 \mathrm{~mm}$ compr., tecas oblíquas, múticas. Estilete ca. 1,8 cm compr., esparsamente pubescente; disco nectarífero cupular. Cápsula 4-5 cm compr., pubescente a pilosa, com porção fértil ovoide; sementes 4, 1-1,5 cm diâm., suborbiculares, tuberculadas, borda gloquidiada.

Material selecionado: BRASIL. BAHIA: Feira de Santana, Distrito de Ipuaçu, Estrada do Feijão, fazenda Chapada do Senhor Morais, $12^{\circ} 13^{\prime} \mathrm{S} 39^{\circ} 4^{\prime} \mathrm{W}$, 5-IX-2007, fl., fr., bot., A.L.A. Côrtes et al. 30 (HUEFS); Macaúbas, estrada para Bom Jesus da Lapa, entre o alto da Serra Poções e a Lagoa Maurício, 15-VI-2004, fl., G. Hatschbach et al. 77868 (MBM); Paramirim, no caminho de Caturama para Mateus, $13^{\circ} 17^{\prime} 50$ "S 42¹4'44"W, 593 m s.n.m., 28-IV-2007, fl., fr., bot., A.A. Conceição et al. 1924 (HUEFS).

Material adicional examinado: BRASIL. PIAUi: 1840, fl., G. Gardner 2462 (tipo B destruído - foto F!).

Dicliptera mucronifolia caracteriza-se pelos fascículos axilares e terminais e as brácteas verde-claras, desiguais e longamente ciliadas. Nees (1847a) comentou que $D$. ciliaris Juss. é próxima a D. mucronifolia, da qual se distinguiria principalmente pela pubescência das brácteas, e sugeriu que pudessem representar variedades de uma mesma espécie. No entanto, são necessários estudos mais amplos para que se possa definir a identidade desses táxons.

É comum na Caatinga arbustiva com solo argiloso ou pedregoso, em altitudes entre 200 e 600 m s.n.m. Está distribuída na região semiárida dos Estados de Piauí, Ceará, Rio Grande do Norte, Paraíba, Pernambuco, Alagoas, Sergipe, Bahia e Minas Gerais, chegando até São Paulo, Espírito Santo e Rio Grande do Sul (Rambo 1964). Floresce e frutifica de abril a novembro.

4. Harpochilus Nees in Martius, Fl. Bras. 9: 146. 1847.

Arbustos; ramos canescentes. Folhas pecioladas ou sésseis. Inflorescências em tirsos ou espigas, axilares ou terminais, com 1-3 flores por nó; 1 bráctea e 2 bractéolas. Cálice com (3-)5 lacínias, desiguais. Corola amarelo-esverdeada ou creme, bilabiada, não ressupinada; lábio superior côncavo ou curvo, bilobado no ápice; lábio inferior trilobado, com lobos curvados, amplos ou estreitos. Androceu com 2 estames exsertos, anteras bitecas, tecas paralelas ou oblíquas, múticas ou apendiculadas na base, glabras, estaminódios ausentes. Cápsulas obovadas, estipitadas; sementes 4.

O gênero, que contava com três espécies, foi reduzido a duas espécies endêmicas do Nordeste: H. neesianus Mart. ex Nees e H. phaeocarpus Nees. Harpochilus trimerocalyx Rizzini foi sinonimizado em Anisacanthus trilobus (Côrtes et al. 2010). Nas análises filogenéticas da tribo (McDade et al. 2000a), $H$. neesianus aparece no clado das "Justicioides" do Novo Mundo, porém as distinções morfológicas entre 


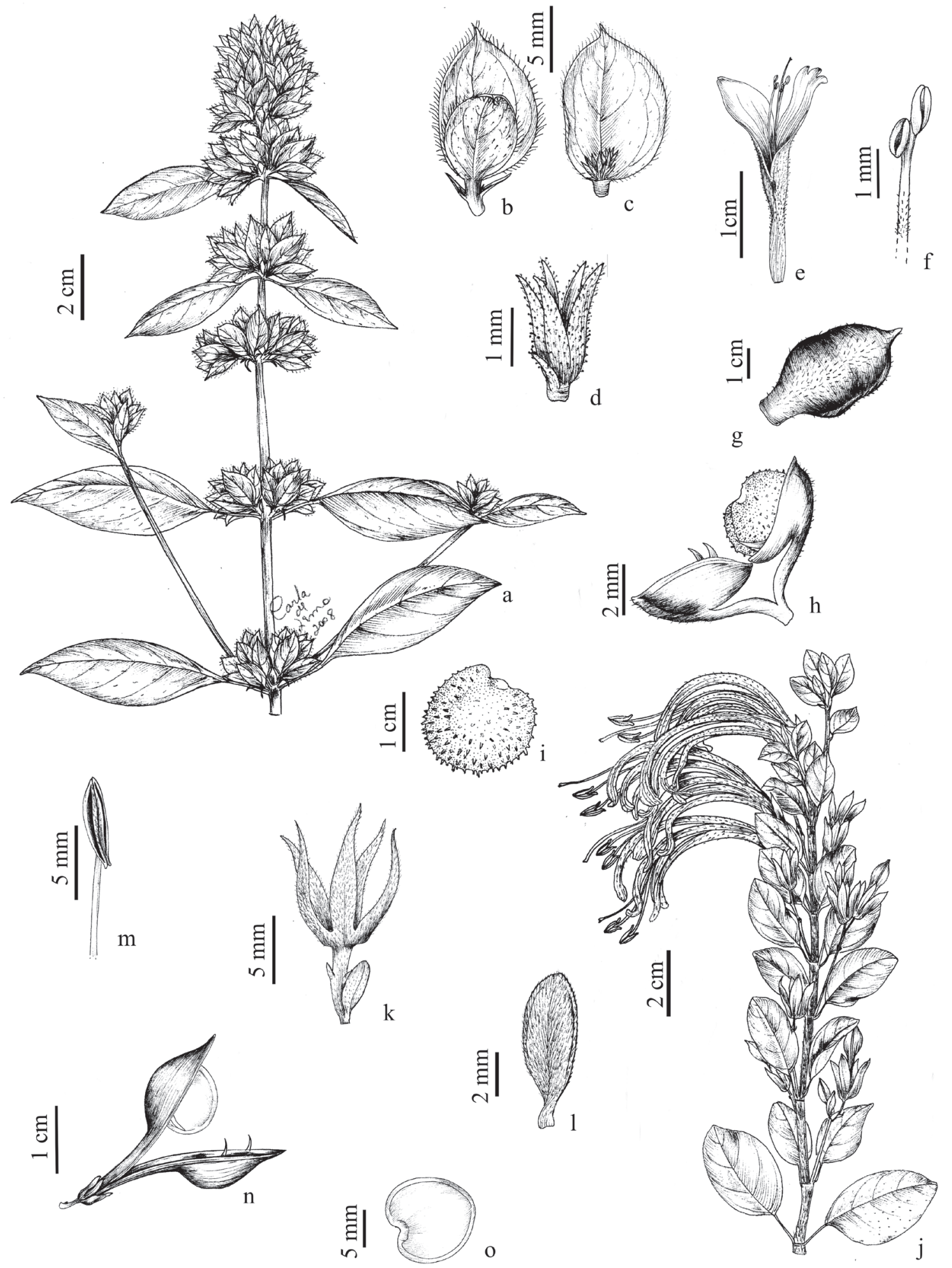

Figura 3. a-i. Dicliptera mucronifolia. a. Ramo florido. b. Brácteas. c. Bráctea, bractéolas e cálice. d. Bractéola e cálice. e. Corola com estames e estilete. f. Estame. g. Fruto. h. Fruto com semente. i. Semente. j-o. Harpochilus neesianus. j. Ramo florido. k. Bráctea, bractéolas e cálice. 1. Bráctea, face adaxial. m. Estame. n. Fruto com semente. o. Semente. (a-i. Côrtes 30; j-o. Atkinson 2486).

Figure 3. a-i. Dicliptera mucronifolia. a. Flowering branch. b. Bracts. c. Bract, bracteoles and calyx. d. Bracteole and calyx. e. Corolla with stamens and style. f. Stamen. g. Fruit. h. Fruit with seed. i. Seed. j-o. Harpochilus neesianus. j. Flowering branch. k. Bract, bracteoles and calyx. 1. Bract, adaxial surface. m. Stamen. n. Fruit with seed. o. Seed. (a-i. Côrtes 30; j-o. Atkinson 2486). 
essas espécies de Harpochilus e as de Justicia foram pouco investigadas e novas evidências vêm apontando uma maior proximidade entre Harpochilus e Clistax (McDade, dados não publicados).

Chave para espécies de Harpochilus do Semiárido da Bahia

1. Lâmina foliar 2-7,5 cm compr., sem pontuações glandulares; inflorescência em tirso; corola esverdeada, lábios estreitos; anteras com tecas mais de $5 \mathrm{~mm}$ compr., apêndice ausente H. neesianus

1. Lâmina foliar $7-13 \mathrm{~cm}$ compr., compontuações glandulares; inflorescência em espiga; corola creme, lábios amplos; anteras com tecas ca. $3 \mathrm{~mm}$ compr., a inferior apendiculada H. phaeocarpus

4.1. Harpochilus neesianus Mart. ex Nees in Martius, F1. Bras. 9: 146, t. 24.1847.

Nome comum: brinco, camará, caneta, cansa-cavalo, canudo, canudo da Caatinga, canudo-de-cachimbo, tamaratá (in sched.).

Figuras $3 \mathrm{j}-\mathrm{o}, 5,17 \mathrm{c}$

Arbusto, 1,5-3 m alt.; ramos subquadrangulares com estrias finas, inconspícuas e tomentosos. Pecíolo 0,1-1,7 cm compr., lâmina 2-7,5 × 1-2,4 cm, oblonga a elíptica ou ovada a obovada, vilosa a tomentosa, ápice obtuso a agudo, base obtusa a cuneada. Inflorescência em tirsos axilares, dicásios pedunculados 0,8-1 cm compr.; brácteas 1-7 × 1-2 mm, lineares a oblanceoladas, vilosas; bractéolas ca. $1 \times 0,5 \mathrm{~mm}$, lineares, vilosas. Cálice ca. 1,1 cm compr.; lacínias $0,9-1,9 \times 0,1-0,3 \mathrm{~cm}$, lanceoladas a lineares ou estreitamente oblongas, adaxialmente velutinas a vilosas, abaxialmente pubescentes. Corola esverdeada, 7-9,5 cm compr., internamente glabra a pubescente, externamente pubescente, coberta com tricomas glandulares, tubo 1,8-2 cm compr., ereto, lábio superior 5,5-7,5 $\times$ ca. $0,5 \mathrm{~cm}$, bilobado no ápice, lábio inferior 4,5-6 $\times$ ca. $0,3 \mathrm{~cm}$, estreito. Filetes $5,4-6,3 \mathrm{~cm}$ compr., anteras 6-7 $\mathrm{mm}$ compr., tecas paralelas, múticas. Estilete ca. $8 \mathrm{~cm}$ compr., glabro; disco nectarífero anular. Cápsula 1,7-3,7 cm compr., glabra, com porção fértil obovoide; sementes $0,5-1 \mathrm{~cm}$ diâm., orbiculares, lisas, borda inteira.

Material selecionado: BRASIL. BAHIA: rio São Francisco, fr., J.S. Blanchet 2884 (isossíntipo B destruído - foto F!); Barra, Ibiraba, $10^{\circ} 48^{\prime} \mathrm{S} 42^{\circ} 50^{\prime} \mathrm{W}$, 26-II-1997, fl., bot., L.P. Queiroz 4887 (HUEFS); Boquira, Torre da Telebahia, 19-I-1997, fl., bot.,
G. Hatschbach et al. 65990 (CEPEC); Caetité, Caminho para Brejinho das Ametistas, $14^{\circ} 08^{\prime} 48^{\prime \prime} \mathrm{S}$ 42³2'29"W, 960 m s.n.m., 11-II-1997, M.L. Guedes et al. 5441 (ALCB, HRB, HUEFS); Canudos, Estação Ecológica Raso da Catarina, 14-V-1981, fl., bot., H.P. Bautista 444 (CEPEC, HRB); Casa

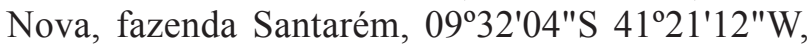
452 m s.n.m., 28-XI-2003, bot., L.P. Queiroz et al. 7997 (HUEFS); Gentio de Ouro, APA de Itaparica $11^{\circ} 07^{\prime} 38^{\prime \prime S} 42^{\circ} 44^{\prime} 23 " \mathrm{~W}, 5-\mathrm{V}-2002$, fl., fr., bot., M.C. Ferreira 1265 (HRB, HUEFS); Glória, Brejo do Burgo, Serrota 11-I-1993, bot., F.P. Bandeira 128 (ALCB, HRB); Jaguarari, Morro do Flamengo, $10^{\circ} 06^{\prime} 01^{\prime \prime S} 40^{\circ} 13^{\prime} 43^{\prime \prime} \mathrm{W}, 635$ s.n.m., 27-VII-2005, fl., fr., bot., P.D. Carvalho et al. 119 (HUEFS); Jeremoabo, fazenda Nova Esperança, 18-I-2006, fl., G.C. Sessegolo et al. 167 (MBM); Juazeiro, Serra do Mulato, 0944'40"S 4040'39"W, 27-III-2000, fl., bot., G. Cavalcanti et al. 63 (HUEFS); Paulo Afonso, Raso da Catarina, Baixa do Chico, 09³1'54"S 38 38'11"W, 544 m s.n.m., 11-VIII-2005, fl., fr., bot., J. Carvalho-Sobrinho et al. 560 (HUEFS); Pilão Arcado, Goiabeira, dunas continentais, 13-VIII-1998, fr., bot., A.M. Miranda et al. 3003 (HUEFS); Ribeira do Pombal, 1044'49"S 38 53'34"W, 235 m s.n.m., 24-II-2006, fr., bot., E. Melo et al. 4265 (HUEFS); Senhor do Bonfim, encosta da crista de quartzito, $10^{\circ} 02^{\prime} 38^{\prime \prime S ~ 40} 13^{\prime} 3 " \mathrm{~W}, 710$ m s.n.m., 14-IV-2005, fl., bot., E. Melo 3792 (HUEFS); Tucano, $23 \mathrm{~km}$ na estrada para Euclides da Cunha, 22-II-1992, fr., bot., A.M. Carvalho et al. 3931 (CEPEC, HUEFS); Uauá, $51 \mathrm{~km} \mathrm{~N}$ de Monte Santo, 25-VIII-1996, fl., bot., L.P. Queiroz \& N.S. Nascimento 4637 (HUEFS); Uibaí, Serra Azul, $11^{\circ} 20^{\prime} 10^{\prime \prime} S 42^{\circ} 08^{\prime} 29^{\prime \prime} \mathrm{W}, 600$ m s.n.m., 17-III-1996, fl., fr., bot., R. Atkinson et al. 2486 (ALCB, HUEFS); Xique-Xique, Dunas do Rio São Francisco, 1047'16"S 4246'22"W, 548 m s.n.m., 23-VI-1996, bot., A.M. Giulietti et al. 2978 (ALCB, HRB, HUEFS).

Harpochilus neesianus é um arbusto com folhas decussadas, corola esverdeada, profundamente bilabiada, com lábios longos, e produz cápsulas relativamente grandes. É registrada para a os Estados da Bahia, Pernambuco e Paraíba, sendo encontrada na Caatinga arbustivo-arbórea, campos rupestres e Cerrado, principalmente em regiões mais áridas, sobre solo geralmente pedregoso ou em afloramentos de arenito avermelhado. É polinizada por morcegos (Vogel et al. 2004), mas também visitada por abelhas e vespas. Floresce e frutifica praticamente o ano todo, de fevereiro a novembro. 


\subsection{Harpochilus phaeocarpus Nees in Martius,}

Fl. Bras. 9: 147. 1847.

Figuras $4 \mathrm{a}-\mathrm{h}$

Arbusto escandente, ca. $2 \mathrm{~m}$ alt.; ramos subquadrangulares a quadrangulares, velutinos a tomentosos. Pecíolo 0,8-1,5 cm compr.; lâmina $7-13 \times 2,3-4,5 \mathrm{~cm}$, elíptica a estreitamente elíptica, com tricomas esparsos e pontuações glandulares, ápice obtuso, base cuneada a levemente decorrente. Inflorescência em espigas, com 1 flor; bráctea 1 , $9-22 \times 2-5 \mathrm{~mm}$, oblanceolada, pubescentes com tricomas glandulares sésseis; bractéolas 2, 5-7 × ca. $1 \mathrm{~mm}$, estreitamente lanceoladas, pubescentes. Cálice 8-9 mm compr., lacínias $6-7 \times$ ca. $3 \mathrm{~mm}$, lanceoladas, esparsamente estrigosas a pubescentes principalmente no ápice. Corola creme com o lobo do lábio central lilás, ca. 1,7 cm compr., internamente glabra, externamente pubescente, tubo ca. $7 \mathrm{~mm}$ compr., ereto, lábio superior ca. $1 \times 1,1 \mathrm{~cm}$, bilobado no ápice, lábio inferior ca. $1 \times 2 \mathrm{~cm}$, amplos. Filetes ca. $7 \mathrm{~mm}$ compr., anteras ca. $3 \mathrm{~mm}$ compr., tecas oblíquas, uma apendiculada na base; disco nectarífero anelar. Cápsula ca. $2 \mathrm{~cm}$ compr., glabra, com porção fértil obovoide; sementes 4 , ca. $4 \mathrm{~mm}$ diâm., orbiculares, borda inteira.

Material examinado: BRASIL. BAHIA: Juazeiro, rio São Francisco, locis herbidis, fr., C.F.P. Martius s.n. (tipo M n.v. - foto F!); Ilhéus, $2 \mathrm{~km} \mathrm{NE} \mathrm{na} \mathrm{estrada} \mathrm{pelo}$ Banco da Vitória para oeste da Mata da Esperança,

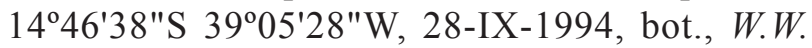
Thomas et al. 10676 (HUEFS, NY); ibid., 17-X-1996, bot., S.C. Sant'Ana et al. 626 (CEPEC, HUEFS).

Os espécimes desse táxon não estavam corretamente identificados nos herbários brasileiros e a descrição original não incluía informações sobre a corola, o androceu, nem o gineceu. A identidade de $H$. phaeocarpus só pode ser esclarecida pela observação do material-tipo. A espécie é facilmente distinguida de H. neesianus, por ser um arbusto com folhas cartáceas (vs. membranáceas), espigas (vs. tirsos), corola creme com o lobo central do lábio inferior central lilás, lobos amplos (vs. totalmente esverdeada, lobos estreitos). Harpochilus phaeocarpus apresenta maior semelhança com Justicia, ou até mesmo com Poikilacanthus, do que com H. neesianus. As brácteas oblanceoladas são parecidas com as brácteas de algumas espécies de Poikilacanthus e a corola com lábios amplos é semelhante àquelas conhecidas em algumas espécies de Justicia. Contudo, mudanças genéricas exigirão novas investigações no complexo das "Justicioides" do Novo Mundo. Nees (1847a) descreveu as duas espécies de Harpochilus a partir de coleções provenientes de Juazeiro, na Bahia. No entanto, não foram encontrados outros espécimes de $H$. phaeocarpus na região semiárida e os registros recentes são exclusivamente da Mata Atlântica do sul da Bahia, o que pode colocar em dúvida a real ocorrência dessa espécie na Caatinga. Está restrita ao Estado da Bahia, florescendo em setembro e outubro.

5. Herpetacanthus Nees ex Moric., P1. Nouv. Amer. 159. 1847.

Ervas a arbustos. Folhas pecioladas. Inflorescência espiga ou tirso, axilar ou terminal, secundiflora; com 1-3 flores por nó; 1 bráctea estéril e 1 fértil conspícuas, e 2 bractéolas inconspícuas. Cálice com 5 lacínias, iguais. Corola bilabiada, não ressupinada; lábio superior ereto a ligeiramente recurvado, bilobado no ápice; lábio inferior trilobado, com lobos curvos. Androceu com 4 estames didínamos, 2 exsertos e 2 inclusos, anteras bi- e monotecas, tecas oblíquas, as dos estames maiores bitecas, as dos menores monotecas, múticas, glabras, estaminódio ausente. Cápsulas elípticas, estipitadas; sementes 4 , às vezes 2 abortadas.

Herpetacanthus pode ser reconhecido pelas espigas ou tirsos secundiflora com fileiras de brácteas estéreis e férteis, corola bilabiada e quatro estames, sendo dois menores e com anteras monotecas. Compreende 18 espécies, distribuídas na Américas Central e Sul (Indriunas 2011, Indriunas \& Kameyama 2012). Em análise filogenética, Herpetacanthus aparece incluído na linhagem Pseuderanthemum, clado-irmão do restante da tribo, caracterizado pelo androceu com quatro estames ou com dois estames e dois estaminódios, uma plesiomorfia da tribo (McDade et al. 2000a).

\subsection{Herpetacanthus magnobracteolatus Idriunas \&}

Kameyama, Syst. Bot. 37(4): 1006-1022. 2012. Figuras 4 i-p, 5, 17 d

Arbusto, 0,5-1 $\mathrm{m}$ alt.; ramos subcilíndricos, glabros a hirtelos. Pecíolo 5-7 mm compr.; lâmina (1-)2,5-8 × (0,6-0,8-)1,5-4 cm, obovado-elíptica a ovada, glabra, às vezes hirtelas na nervura principal, ápice agudo a obtuso ou às vezes apiculado, base cuneada a levemente decorrente. Inflorescência em espigas; brácteas verde-claras a rosadas, 1,4-1,7 × 0,7-1 cm, elípticas a ovadas, glabras, ciliadas (tricomas 0,2-0,3 mm compr.); bractéolas 

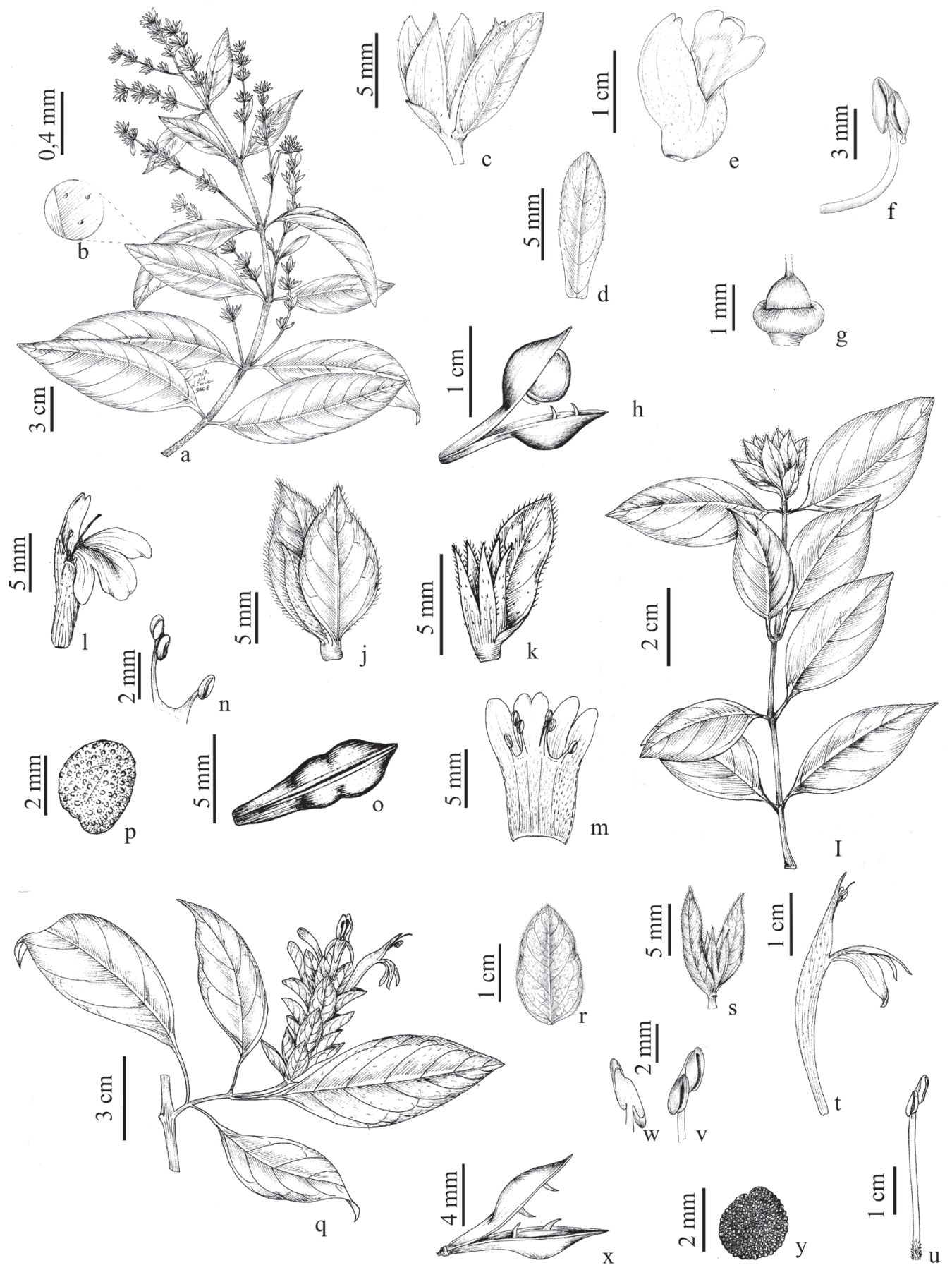

Figura 4. a-h. Harpochilus phaeocarpus. a. Ramo florido. b. Detalhe da folha, mostrando pontuações glandulares. c. Bráctea, bractéola e cálice. d. Bráctea, face abaxial. e. Corola. f. Estame. g. Disco nectarífero e ovário. h. Fruto com semente. i-p. Herpetacanthus magnobracteolatus. i. Ramo florido. j. Brácteas e bractéola. k. Bractéola e cálice. 1. Corola com estame e estilete. m. Corola aberta, evidenciando os estames. n. Par de estames. o. Fruto. p. Semente. q-y. Justicia aequilabris. q. Ramo florido. r. Bráctea, face abaxial. s. Bractéolas e cálice. t. Corola com estame e estilete. u. Estame. v. Antera. w. Antera, evidenciando conectivo. x. Fruto. y. Semente. (a-h. Thomas 10676; i, o-p. Souza 198; j-n. Côrtes 116; q-y. Côrtes 76).

Figure 4. a-h. Harpochilus phaeocarpus. a. Flowering branch. b. Leaf detail, showing gland punctuation. c. Bract, bracteole and calyx. d. Bract, abaxial surface. e. Corolla. f. Stamen. g. Nectariferous disk and ovary. h. Fruit with seed. i-p. Herpetacanthus magnobracteolatus. i. Flowering branch. j. Bracts and bracteole. k. Bracteole and calyx. 1. Corolla with stamen and style. m. Corolla, showing the stamens. n. Stamens. o. Fruit. p. Seed. q-y. Justicia aequilabris. q. Flowering branch. r. Bract, abaxial surface. s. Bracteoles and calyx. t. Corolla with stamen and style. u. Stamen. v. Anther. w. Anther, showing connective. x. Fruit. y. Seed. (a-h. Thomas 10676; i, o-p. Souza 198; j-n. Côrtes 116; q-y. Côrtes 76). 
0,6-1,5 $\times$ ca. $0,2 \mathrm{~cm}$, lanceoladas, esparsamente escabrosas, ciliadas. Cálice 4-8 mm compr., lacínias 3-7 × 1-2 mm, estreitamente lanceoladas, esparsamente escabrosas, ciliadas. Corola alva, ca. 1,3 cm compr., internamente pubescente próximo aos estames e lobos, externamente hirsuta, tubo ca. $9 \mathrm{~mm}$ compr., ereto, lábio superior ca. $3 \mathrm{~mm}$ compr., bilobado no ápice, lábio inferior ca. $4 \times 1 \mathrm{~mm}$. Filetes dos estames maiores ca. $4 \mathrm{~mm}$ compr., dos menores ca. $2 \mathrm{~mm}$ compr.; anteras ca. $1 \mathrm{~mm}$ compr. Estilete ca. $7 \mathrm{~mm}$ compr., glabro. Cápsula 0,9-1 cm compr., glabra, com porção fértil fusiforme e constrita entre as sementes; sementes 4 , ca. $3 \mathrm{~mm}$ compr., suborbiculares, verrucosas, com borda indefinida.

Material examinado: BRASIL. BAHIA: Jequié, Serra do Brejo, fazenda Francisco Brito (Flor), 10,5 km S de Mandacaru, na estrada para Serra do Brejo, 13056'49"S 4006'40"W, 600-700 m s.n.m., 7-IX-2008, fl., fr., bot., A.L.A. Côrtes et al. 116 (HUEFS); Maracás, 23-IV-2002, fr., E.R. Souza et al. 198 (HUEFS).

Herpetacanthus magnobracteolatus é caracterizada pela inflorescência em espiga, com brácteas férteis e estéreis similares, ovadas, verde-claras a rosadas; a corola é pequena, ca. $1,3 \mathrm{~cm}$ compr., alva com lobo central lilás. Segundo Indriunas \& Kameyama (2012), esta espécie se diferencia das demais do gênero pelas bractéolas acrescentes no desenvolvimento do fruto ultrapassarem o tamanho das brácteas. Os espécimes de Mata Atlântica apresentam as brácteas com indumento mais denso e a inflorescência é geralmente mais longa.

Ocorre na transição entre Caatinga e Mata Atlântica, ou mata de cipó, geralmente em áreas com penetração de sol e em altitudes de 600 a $700 \mathrm{~m}$, onde também podem ser encontradas espécies de Justicia,
Stenandrium Nees e Ruellia. Floresce em setembro e frutifica de abril a setembro.

\section{Justicia L., Sp. Pl. 1: 15. 1753.}

Ervas perenes a arbustos; ramos quadrangulares a cilíndricos. Folhas sésseis ou pecioladas. Inflorescências em tirsos, racemos, espigas, cimas ou panículas, axilares ou terminais, com 1 a várias flores por nó; brácteas grandes e coloridas ou inconspícuas; bractéolas geralmente 2. Cálice com 4 ou 5 lacínias desiguais a iguais. Corola bilabiada, não ressupinada; lábio superior côncavo ou ereto, inteiro ou bilobado, com sulco estilar (rúgula); lábio inferior trilobado, geralmente com mácula branca ou pintalgada no lobo central. Androceu com 2 estames exsertos, anteras unitecas ou bitecas, tecas oblíquas a superpostas, basalmente apendiculadas ou múticas, estaminódios ausentes. Cápsulas obovadas ou clavadas, estipitadas; sementes 2-4.

É um dos maiores gêneros de Acanthaceae, com cerca de 600 espécies e distribuição pantropical (Graham 1988). No Brasil, está representado por 126 espécies (Profice et al. 2010) e a Flora Brasiliensis (Nees 1847a) ainda é o tratamento mais completo para o país, reunindo muitos gêneros atualmente sinonimizados em Justicia. É um gênero complexo taxonomicamente, com limites infragenéricos e infraespecíficos problemáticos. A análise filogenética realizada por McDade et al. (2000a) mostraram que o gênero aparece predominantemente no clado das Justicioides do Novo Mundo e no grado denominado Justicioides do Velho Mundo, mas algumas espécies podem se agrupar em outros clados, como na linhagem Tetramerium (Daniel et al. 2008). Apesar disso, as espécies do gênero compartilham a presença de rúgula e os mesmos tipos polínicos (Daniel 1998).

\section{Chave para as espécies de Justicia do Semiárido da Bahia}

\section{Espigas com flores secundifloras}

2. Inflorescência espiciforme; tecas iguais

3. Inflorescência laxa; brácteas triangulares, 1-2 × 0,5-1 mm; corola 1,4-2 cm compr.; sementes tuberculadas, borda lacerada J. laevilinguis

3. Inflorescência congesta; brácteas ovadas, 7-30 × 7-10 mm; corola 2-2,5 cm compr; sementes lisas, borda inteira J. thunbergioides

2. Inflorescência paniculiforme; tecas desiguais

4. Corola vermelha, mais de $2 \mathrm{~cm}$ compr. J. xipotensis

4. Corola alvo-arroxeada, lilás, menos de $2 \mathrm{~cm}$ compr.

5. Corola até $4 \mathrm{~mm}$ compr.; estames com tecas oblíquas (conectivo curto), a superior até $0,4 \mathrm{~mm}$ compr., a inferior até $0,3 \mathrm{~mm}$ compr. J. comata

5. Corola com 0,9-1,5 mm compr.; estames com tecas superpostas (conectivo longo), a superior ca. $1 \mathrm{~cm}$ compr., a inferior mais de $4 \mathrm{~mm}$ compr. 
1. Espigas ou racemos com flores opostas

7. Brácteas ovadas, elípticas, espatuladas ou orbiculares

8. Brácteas espatuladas ou orbiculares; corola creme

9. Lâmina foliar até $9 \mathrm{~cm}$ compr., elíptica; brácteas orbiculares; corola ca. $1 \mathrm{~cm}$ compr.; estames com tecas superpostas, iguais J. cuneifolia

9. Lâmina foliar com mais de $9 \mathrm{~cm}$ compr., largamente elíptica; brácteas espatuladas; corola ca. $3 \mathrm{~cm}$ compr.; estames com tecas oblíquas, desiguais

J. congrua

8. Brácteas ovadas a elípticas; corola lilás ou vermelha.

10. Corola vermelha, 3,8-4 cm compr., tubo ca. $2,5 \mathrm{~cm}$ compr. J. aequilabris

10. Corola lilás, $1,5-3 \mathrm{~cm}$ compr., tubo ca. $0,5-1,2 \mathrm{~cm}$ compr.

11. Pecíolo 1,5-5 cm compr.; lâmina foliar elíptica a obovada, 8,5-18 cm compr.

J. attenuata

11. Pecíolo 0,5-1,5 cm compr.; lâmina foliar ovada, 0,8-9 cm compr.

12. Corola ca. $2 \mathrm{~cm}$ compr., lábio superior ca. $4 \mathrm{~mm}$ compr., lábio inferior estreito, lobos 0,4-0,43 cm larg.; anteras sem apêndices; cápsulas com a porção fértil fusiforme, até $6 \mathrm{~mm}$ compr.

J.jacuipensis

12. Corola ca. $3 \mathrm{~cm}$ compr., lábio superior ca. $2 \mathrm{~cm}$ compr., lábio inferior largo, 0,8-1,2 cm larg.; anteras com a teca inferior apendiculada; cápsulas com a porção fértil obovoide, mais de $6 \mathrm{~mm}$ compr. J. chlamidocalyx

7. Brácteas lineares, lanceoladas ou triangulares

13. Cálice quadripartido

14. Cálice 12-20 × 2-4 mm; corola vermelha ou rósea, 4,5-5 cm compr., tubo 1,7-2,5 cm compr. ... J. lepida

14. Cálice 7-11 × 0,3-1,5 mm; corola lilás, 0,7-3 cm compr., tubo 0,3-2 cm compr.

15.Erva 8-30 cm alt.; espigas $2-14 \mathrm{~cm}$ compr.; brácteas até $3 \mathrm{~mm}$ compr., triangulares; tecas oblíquas J. chamaedryoides

15. Arbusto ca. $50 \mathrm{~cm}$ alt.; espigas até 1,5 cm compr.; brácteas 7-10 mm compr., lanceoladas; tecas superpostas J. harleyi

13. Cálice quinquipartido

16. Corola até $2 \mathrm{~cm}$ compr.; tecas paralelas, múticas J. angustissima

16. Corola $\geq 2 \mathrm{~cm}$ compr.; tecas oblíquas a superpostas, apendiculadas

17. Brácteas lineares; corola externamente com tricomas glandulares; filetes ca. $10 \mathrm{~mm}$ compr; cápsulas ca. $1,9 \mathrm{~cm}$ compr. J. asclepiadea

17. Brácteas lanceoladas; corola externamente sem tricomas glandulares; filetes até $7 \mathrm{~mm}$ compr; cápsulas até $1 \mathrm{~cm}$ compr. J. simonisia

6.1. Justicia aequilabris (Nees) Lindau in Engler \&

Prantl, Nat. Pflanzenfam. 4(3b): 350. 1895. Nome comum: sipipira, erva-de-preá, camarão (in sched.).

Figuras $4 \mathrm{u}-\mathrm{y}, 7,17 \mathrm{e}$

Arbusto ereto a subscandente, 0,5-2 m alt.; ramos cilíndricos, pubescentes a glabros. Pecíolo 2-10 mm compr.; lâmina 3-11 × 1,2-4,2 cm, ovada, oblonga a elíptica, adaxialmente glabra a pubescente, abaxialmente pilosa, ápice agudo a acuminado, base cuneada a atenuada. Inflorescências em espigas, axilares e terminais; brácteas verdes, às vezes as apicais com borda arroxeada, 1,2-2,4 × 0,5-1,3 cm, elípticas a lanceoladas ou ovadas, adaxialmente glabras a pubescentes, abaxialmente pubescentes a pilosas ou papilosas, às vezes com tricomas glandulares, ciliadas, tricomas ca. $1 \mathrm{~mm}$ compr.; bractéolas $0,9-1,8 \times$ ca. $0,1 \mathrm{~cm}$, lanceoladas a lineares, adaxialmente glabras, abaxialmente pubescentes, ciliadas. Cálice 5-6 mm compr., lacínias 5, 4-5 × ca. $1 \mathrm{~mm}$, lanceoladas, adaxialmente glabras a esparsamente pilosas, abaxialmente esparsamente pilosas, ciliadas. Corola vermelha, 3,8-4,2 cm compr., internamente glabra, tornando-se pubescente no tubo, externamente hirtela (escabra no botão), tubo ca. $2,5 \mathrm{~cm}$ compr., ereto, lábio superior ca. $1,9 \times 0,5 \mathrm{~cm}$, bilobado no ápice, lábio inferior ca. $10 \times 3-4 \mathrm{~cm}$. Filetes ca. $3 \mathrm{~cm}$ compr., anteras ca. $2 \mathrm{~mm}$ compr., tecas oblíquas, múticas. Estilete ca. 3,5 cm compr., glabro; disco nectarífero cupular. Cápsula ca. $1 \mathrm{~cm}$ compr., glabrescente, com porção fértil obovoide; sementes 4, ca. $2 \mathrm{~mm}$ diâm., suborbiculares, tuberculadas, borda tuberculada. 
Material selecionado: BRASIL. BAHIA: Bonfim de Feira, $12^{\circ} 15^{\prime} 32^{\prime \prime S} 39^{\circ} 5^{\prime} 47^{\prime \prime} \mathrm{W}, 303$ m s.n.m., 18-I-2007, fr., E. Melo et al. 4625 (HUEFS); Bom Jesus da Lapa, $11 \mathrm{~km} \mathrm{~S}$ do entroncamento na estrada para Malhada, $13^{\circ} 41^{\prime} 08^{\prime \prime S} 43^{\circ} 28^{\prime} 06^{\prime \prime} \mathrm{W}, 11-\mathrm{II}-2000$, fl., L.P. Queiroz et al. 5894 (HUEFS); Carinhanha, rodovia para Serra do Ramalho, 10,5 km da sede municipal, $14^{\circ} 12^{\prime} 29^{\prime \prime S}$ 434'04"W, 470 m s.n.m., 15-IV-2001, fl., J.G. Jardim et al. 3535 (HRB, HUEFS); Caturama, estrada de terra entre Caieiras e Tamboril, $13^{\circ} 17^{\prime} 47^{\prime \prime S} 42^{\circ} 12^{\prime} 47^{\prime \prime} \mathrm{W}$, 22-IV-2008, fl., A.L.A. Côrtes et al. 99 (HUEFS); Feira de Santana, Ipuaçu, Monte Alto, $12^{\circ} 13^{\prime} 58^{\prime \prime S}$ 3904'34"W, 212 m s.n.m., 19-VII-2007, fl., A.L.A. Côrtes et al. 18 (HUEFS); Ipecaetá, fazenda Riachão, Serra Orobozinho, $12^{\circ} 20^{\prime}$ S $39^{\circ} 17^{\prime} \mathrm{W}, 14-\mathrm{VIII}-1985$, fl., L.R. Noblick \& C.G. Lobo 4293 (HUEFS); Jacobina, margem esquerda do rio Jacuípe, 28-III-1985, fl., B.C. Bastos 413 (HUEFS); Monte Santo, $11 \mathrm{~km} \mathrm{E}$ da cidade, para Euclides da Cunha, 24-VIII-1996, fl., fr., L.P Queiroz \& N.S. Nascimento 4575 (HUEFS, HRB); Palmeiras, s.d., P.D. Carvalho 12 (HUEFS); Paramirim, Caieiras, $13^{\circ} 17^{\prime} 13^{\prime \prime} \mathrm{S} 42^{\circ} 12^{\prime} 47^{\prime \prime} \mathrm{W}$, 634 m s.n.m., 29-IV-2007, fl., fr., A.A. Conceição et al. 1995 (HUEFS); Quijingue, Serra das Candeias, $5 \mathrm{~km}$ W do Povoado Quixaba do Mandacaru,

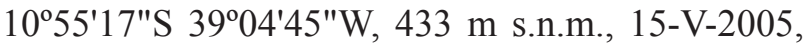

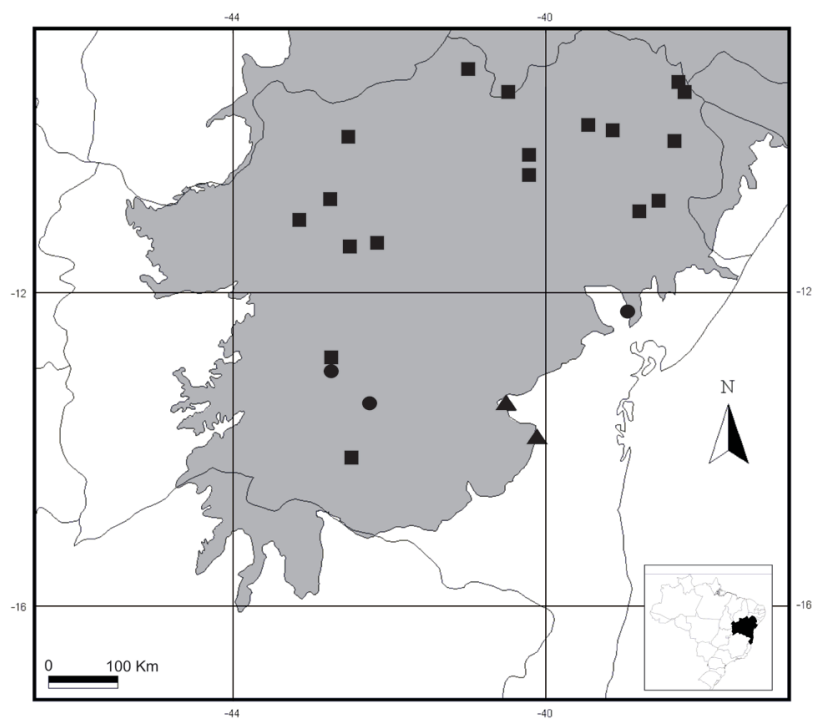

Figura 5. Distribuição de Dicliptera mucronifolia $(\mathbf{\bullet})$, Harpochilus neesianus $(\boldsymbol{\square})$ e Herpetacanthus magnobracteolatus $(\boldsymbol{\Delta})$ no Semiárido do Estado da Bahia, Brasil (área cinza).

Figure 5. Distribution of Dicliptera mucronifolia $(\mathbf{O})$, Harpochilus neesianus $(\boldsymbol{\square})$, and Herpetacanthus magnobracteolatus $(\boldsymbol{\Delta})$ in the Semiarid of Bahia State, Brazil (gray area). fl., fr., D.B.O.S. Cardoso et al. 526 (HUEFS); Rio de Contas, 12,5 km de Rio de Contas estrada em direção a Jussiape, margem direita da estrada, $13^{\circ} 35^{\prime} 55^{\prime \prime} \mathrm{S}$ 41ํㄴ'12"W, 707 m s.n.m., 26-III-2008, fl., fr., bot., A.L.A. Côrtes et al. 76 (HUEFS); Santa Bárbara, 1156'S 3857'W, 20-XII-1992, fl., L.P. Queiroz et al. 3033 (HUEFS, HRB); Tucano, Povoado do Quererá, ao lado da torre de telecomunicações, $11^{\circ} 07^{\prime} 22^{\prime \prime} \mathrm{S}$ $38^{\circ} 44^{\prime \prime} 56^{\prime \prime W, ~} 260$ m s.n.m., 7-I-2006, fl., D.B.O.S. Cardoso \& A.M. Bastos 969 (HUEFS).

Muitas espécies descritas por Nees e Lindau foram sinonimizadas sob $J$. aequilabris, o que demonstra a variabilidade morfológica da espécie, possivelmente associada à sua ampla distribuição. Wasshausen \& Wood (2003), analisando populações na Bolívia, dividiram $J$. aequilabris em três subespécies geograficamente isoladas, com base nas brácteas. No Estado da Bahia, é encontrada a subespécie típica, que se distingue pelas brácteas ovadas, margem ciliada e comumente pubescentes nas nervuras, com o ápice agudo a obtuso. Uma espécie próxima a ela é $J$. serrana Kameyama, que possui folhas levemente crenadas, pilosas, com ápice mucronado e brácteas mais estreitas $(0,7-1 \times 0,2-0,4 \mathrm{~cm})$ e pilosas.

Justicia aequilabris caracteriza-se pelas espigas com brácteas imbricadas e esverdeadas, normalmente ovadas, e pela corola vermelha, com mais de $3 \mathrm{~cm}$ compr., com linhas esbranquiçadas no lobo central. Tem ampla distribuição, ocorrendo na bacia do Rio Grande, na Bolívia Central, Nordeste do Paraguai (Ezcurra 2002), Mato Grosso do Sul, Semiárido de Minas Gerais, Bahia, Alagoas, Pernambuco e Ceará. Habita em Cerrados, Caatingas e bordas de mata estacional. Floresce geralmente no verão e outono, frutificando a partir do final do outono e no inverno.

6.2. Justicia angustissima A.L.A. Côrtes \& Rapini, Kew Bull. 66(3): 454, fig. 1a-1. 2011. Figura 7

Arbusto ca. $1 \mathrm{~m}$ alt.; ramos subcilíndricos, glabros a esparsamente hirsutos. Pecíolo 0,1-1 cm compr.; lâmina 2,5-6 × 1-3,5 cm, elíptica a ovada, com tricomas esparsos nas nervuras em ambas as faces, ciliada, ápice acuminado, base cuneada a levemente decorrente. Inflorescência em espigas terminais; brácteas, $2-5 \times$ ca. $0,8 \mathrm{~mm}$ compr., estreitamente triangulares, adaxialmente glabras, abaxialmente pubescentes, ciliadas; bractéolas 2-3 $\times$ ca. $0,6 \mathrm{~mm}$ compr., no mais similares, às brácteas. Cálice 0,6-1,2 cm compr., lacínias 5, 5-10 × ca. 0,5 mm, 
estreitamente triangulares a lineares, adaxialmente estrigosas, abaxialmente pubérulas, com tricomas glandulares, ciliadas. Corola lilás, com fauce branca, 1,7-2 cm compr., internamente esparsamente pilosa no tubo, glabra nos lobos, externamente esparsamente pilosa, tubo 1,3-1,5 cm compr., ereto, lábio superior ca. $5 \times 1 \mathrm{~mm}$, levemente bilobado no ápice, lábio inferior 5-6 $\times$ ca. $3 \mathrm{~mm}$. Filetes ca. $3 \mathrm{~mm}$ compr., anteras ca. $1 \mathrm{~mm}$ compr., tecas paralelas, múticas. Estilete ca. $1 \mathrm{~cm}$ compr., glabro; disco nectarífero anular. Cápsula ca. $1 \mathrm{~cm}$ compr., glabra, com porção fértil obovoide; sementes 4, ca. $3 \mathrm{~mm}$ diâm., suborbiculares, tuberculada, borda gloquidiada.

Material examinado: BRASIL. BAHIA: Caetité, área de mata na saída para Bom Jesus da Lapa, 135' $10^{\prime \prime S}$ 42027'15"W, 1.023 m s.n.m., 12-IV-2005, fl., fr., bot., E.B. Miranda et al. 802 (HUEFS); Morro do Chapéu, fazenda São João dos Brejões, rio Salitre, $11^{\circ} 16^{\prime} 01^{\prime \prime S ~} 41^{\circ} 05^{\prime} 21^{\prime \prime W}, 720$ m s.n.m., 14-IV-2007, fl., E. Melo et al. 4692 (HUEFS); Oliveira dos Brejinhos, estrada Canabrava a Chapadão de Cima, 16-III-1998, fl., G. Hatschbach et al. 67794 (MBM); Rio de Contas, $12,5 \mathrm{~km}$ de Rio de Contas estrada em direção a Jussiape, borda direita da estrada,

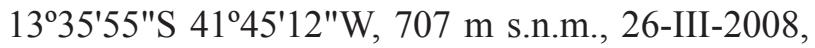
fl., fr., bot., A.L.A. Côrtes et al. 77 (HUEFS); ibid. $12,5 \mathrm{~km}$ na estrada para Jussiape, $13^{\circ} 35^{\prime} 55^{\prime \prime S}$, 41 ${ }^{\circ} 45^{\prime} 12^{\prime \prime W}, 707$ m s.n.m., 26-II-2004, R.M. Harley et al. 54973 (HUEFS); Rio do Antônio, 14²13'S $42^{\circ} 28^{\prime} \mathrm{W}, 26-I I I-1984$, fl., bot., L.C. Oliveira Filho \& J.C.A. Lima 127 (HUEFS); São Gabriel, estrada para Bunina, $11^{\circ} 01^{\prime} \mathrm{S}, 40^{\circ} 39^{\prime} \mathrm{W}, 700$ m s.n.m., 12-IV-2009, R. Machado et al. 245 (HUEFS).

Pode ser reconhecida pelas espigas estreitas e longas, as brácteas e bractéolas estreitamente triangulares, os lobos do cálice lineares, com tricomas glandulares, e a corola lilás com fauce e tubo brancos. É encontrada na Caatinga, geralmente na borda da vegetação. Endêmica do Estado da Bahia. Floresce e frutifica entre março a abril.

6.3. Justicia asclepiadea (Nees) Wassh. \& C. Ezcurra, Candollea 52(1): 172. 1997.

Figuras $6 \mathrm{a}-\mathrm{g}, 7,17 \mathrm{f}$

Arbusto ereto a prostrado, $25-70 \mathrm{~cm}$ alt.; ramos subcilíndricos, pubescentes a hirsutos ou glabrescentes. Pecíolo 2-5 mm compr., lâmina 1,7-5,2 × 0,6-2,2 cm, elíptica a ovada, glabras a esparsamente hirsutas, tricomas concentrados na nervura principal em ambas as faces, ápice agudo a atenuado, base aguda a obtusa ou levemente decorrente. Inflorescência em espigas axilares e terminais, com 1-3 flores; brácteas 0,6-1 × 1-1,2 mm, estreitamente lanceoladas, hirsutas, com tricomas glandulares concentrados no ápice da face adaxial; bractéolas 6-9 × 1-1,2 mm, estreitamente lanceoladas, indumento similar ao das brácteas. Cálice 1,1-1,6 cm compr., lacínias 5, 1-1,5 cm $\times 2-3,5 \mathrm{~mm}$, lanceoladas, hirsutas. Corola lilás com listras brancas, 2-3,5 cm compr., internamente com 3 tufos de tricomas próximo à base do tubo, externamente hirtela, com tricomas glandulares, tubo 1,3-1,9 cm compr., curvo, lábio superior 0,8-1,2 × 0,9-1,3 cm, bilobado no ápice, lábio inferior 1,1-1,7 ×0,5-1,2 cm. Filetes ca. $1 \mathrm{~cm}$ compr., tecas superiores 1,5-2,5 mm compr., dorsalmente pilosa, a inferior 2-3 mm compr., oblíquas, a inferior apendiculada na base. Estilete 1-2,8 cm compr., basalmente pubescente; disco nectarífero cupular. Cápsula ca. 1,9 cm compr., glabra, com porção fértil obovoide; sementes 4, ca. $3 \mathrm{~mm}$ diâm., arredondadas, lisas, borda inteira.

Material selecionado: BRASIL. BAHIA: Caetité, estrada de terra, ca. $14 \mathrm{~km}$ de Caetité em direção a Mamiaçu, 1356'58,4"S 42²7'6,8"W, 890 m s.n.m., 21-IV-2008, fl., A.L.A. Côrtes et al. 89 (HUEFS); Gentio do Ouro, estrada de terra para Ipupiara, 11'27'54"S 42³1'38"W, 1.139 m s.n.m., 17-V-2002, fl., E.R. Souza et al. 288 (HUEFS); Igaporã, estrada para Tanque Novo, 9,2 km após o trevo, 1343'50,1"S 42³6'29,4"W, 902 m s.n.m., 22-IV-2008, fl., A.L.A. Côrtes et al. 96 (HUEFS); Macaúbas, Lagoa do Maurício, 3-5 km E da cidade, 15-VI-2004, fl., fr., G. Hatschbach et al. 77857 (MBM); Paramirim, em direção a Caetité, estrada de terra próximo ao povoado Barro Branco, 22-IV-2008, fl., A.L.A. Côrtes et al. 98 (HUEFS).

Justicia asclepiadea é caracterizada pela inflorescência em pequenas espigas axilares e terminais, com brácteas lineares e às vezes patentes, bem distintas do cálice, lacínias do cálice geralmente com uma faixa esbranquiçada na borda, corola com lábios amplos e estames curvos. É conhecida na Bolívia e no Brasil (Wasshausen \& Wood 2004). Nos Estados de Minas Gerais, Bahia, Goiás e Piauí. Na Bahia, ocorre normalmente em áreas de Caatinga arbórea ou de afloramentos rochosos, em altitudes entre 800 e 1.000 m. No Estado do Mato Grosso possui folhas estreitamente lanceoladas (ca. $5 \times 0,4 \mathrm{~cm}$ ), ocorrendo em Cerrados e matas de galeria com elevação em torno de $500 \mathrm{~m}$. Floresce e frutifica entre abril a junho. 

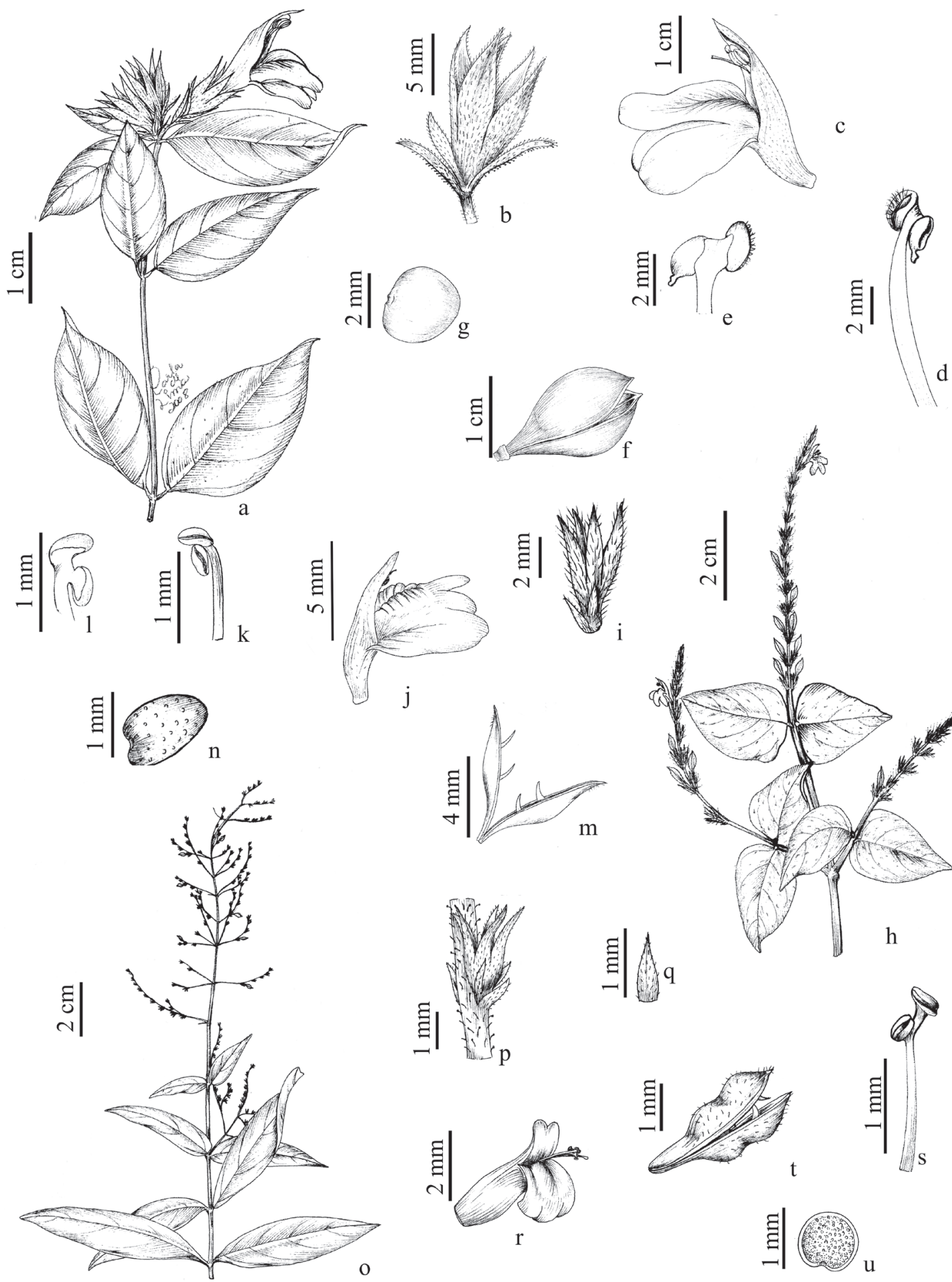

Figura 6. a-g. Justicia asclepiadea. a. Ramo florido. b. Bráctea, bractéolas e cálice. c. Corola com estames e estilete. d. Estame. e. Antera. f. Fruto. g. Semente. h-n. J. chamaedryoides h. Ramo florido. i. Bráctea, bractéola e cálice. j. Corola. k. Estame. 1. Antera. m. Fruto. n. Semente. o-u. J. comata. o. Ramo florido. p. Brácteas, bractéolas e cálice. q. Bráctea, face abaxial. r. Corola com estames e estilete. s. Estame. t. Fruto. u. Semente. (a-h. Hatschbach 77857; i-n. Côrtes 75; o-u. Jardim 3625).

Figure 6. a-g. Justicia asclepiadea. a. Flowering branch. b. Bract, bracteoles and calyx. c. Corolla with stamens and style. d. Stamen. e. Anther. f. Fruit. g. Seed. h-n. J. chamaedryoides. h. Flowering branch. i. Bract, bracteole and calyx. j. Corolla. k. Stamen. 1. Anther. m. Fruit. n. Seed. o-u. J. comata. o. Flowering branch. p. Bract, bracteoles and calyx. q. Bract, abaxial surface. r. Corolla with stamens and style. s. Stamen. t. Fruit. u. Seed. (a-h. Hatschbach 77857; i-n. Côrtes 75; o-u. Jardim 3625). 
6.4. Justicia attenuata A.L.A. Côrtes \& Rapini, Kew Bull. 66(3): 456, fig. 1 m-v. 2011.

\section{Figura 7}

Arbusto, ca. 2 m alt.; ramos subquadrangulares a quadrangulares, pubescentes. Pecíolo 1,5-5 cm compr.; lâmina $8,5-18 \times 5-8,5 \mathrm{~cm}$, elíptica a obovada, adaxialmente glabra a esparsamente pubescente, abaxialmente esparsamente pubescente, ciliada, ápice agudo a obtuso, base longamente decorrente. Inflorescência em espigas terminais; brácteas $1,2-1,5 \times$ ca. $0,5 \mathrm{~cm}$, ovadas a elípticas, pubescentes; bractéolas 1,2-1,5 × 0,3-0,35 cm, lanceoladas, pubescentes. Cálice ca. 1,1 cm compr.; lacínias 5, ca. $10 \times 2,5 \mathrm{~mm}$, lanceoladas, adaxialmente glabras, abaxialmente pubescentes. Corola lilás, ca. 1,5 cm compr., internamente com tufos de tricomas no tubo, externamente pubescente com tricomas glandulares, tubo ca. $5 \mathrm{~mm}$ compr., curvo, lábio superior ca. $8 \times 5 \mathrm{~mm}$, bilobado no ápice, lábio inferior ca. $8 \times 2-4 \mathrm{~mm}$. Filetes ca. $3 \mathrm{~mm}$ compr., anteras ca. $3 \mathrm{~mm}$ compr., tecas oblíquas, a superior pubescente dorsalmente, a inferior apendiculada. Estilete ca. 1,5 cm compr., pubescente na base; disco nectarífero cupular. Cápsula não vista.

Material examinado: BRASIL. BAHIA: Coribe, $5 \mathrm{~km} \mathrm{~S}$ estrada de terra que cruza pequeno ramal que sai a

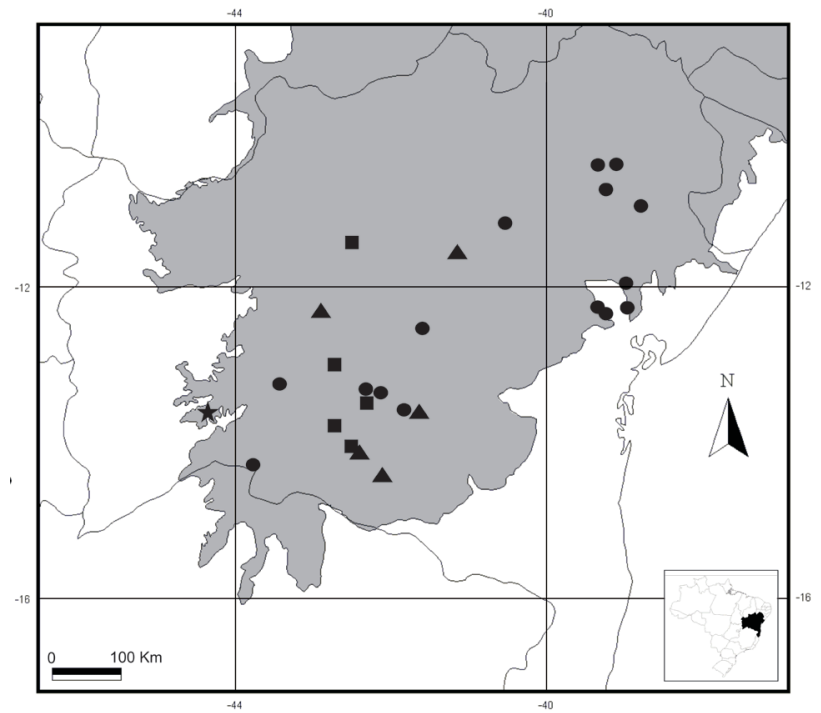

Figura 7. Distribuição de Justicia aequilabris (-), J. angustissima

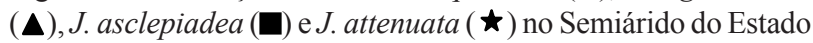
da Bahia, Brasil (área cinza).

Figure 7. Distribution of Justicia aequilabris (-), J. angustissima $(\mathbf{\Delta})$, J. asclepiadea $(\mathbf{\square})$ and J. attenuata $(\boldsymbol{\star})$ in the Semiarid of Bahia State, Brazil (gray area).
5,1 km E de Ponto d'água, a 24,4 km S São Félix

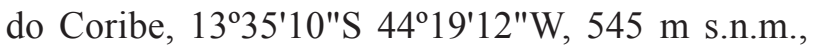
11-IV-2007, fl., bot., L.P. Queiroz et al. 12791 (HUEFS).

É caracterizada pelo pecíolo longo e pelas folhas grandes (até $18 \mathrm{~cm}$ compr.), elípticas a obovadas, longamente decorrentes no pecíolo. A inflorescência é terminal com as brácteas lanceoladas, verdes, e a corola possui lábio inferior amplo e reflexo. Conhecida até então apenas pelo material-tipo foi coletada em floresta estacional, com flores em abril.

6.5. Justicia chamaedryoides (Nees) Wassh. ex

A.L.A. Côrtes \& P.L.R. Moraes, comb. nov. Basiônimo: Rhytiglossa chamaedryoides Nees in Martius, Fl. Bras. 9: 123. 1847. Tipo: BRASIL. BAHIA: local não indicado, III-1817, M.A.P. Wied-Neuwied s.n. (Lectótipo aqui designado por P.L.R. Moraes \& A.L.A. Côrtes [BR 6951993!]; Isolectótipo [GZU 000250286!]).

Nome comum: mentrasto (in sched.).

Figuras 6 h-n, 9, $17 \mathrm{~g}$

Erva ereta, 8-30 cm alt.; ramos subquadrangulares, sulcados, com tricomas normalmente concentrados próximos aos sulcos. Pecíolo 1-5 mm compr.; lâmina 1-8 × 0,8-4,5 cm, elíptica, largamente ovada a ovada, esparsamente hirsutas, tricomas concentrados na nervura principal de ambas as faces, ápice agudo a apiculado, base cuneada a levemente decorrente. Inflorescência em espigas axilares e terminais; brácteas 1,3-3 $\times 0,2-1,5 \mathrm{~mm}$, triangulares, adaxialmente glabras, abaxialmente hirsutas, ciliadas; bractéolas 1-2 $\times 0,1-0,3 \mathrm{~mm}$, triangulares a lineares, indumento similar ao das brácteas. Cálice 4-7 mm compr., lacínias 4, 3-6 × 0,2-1,5 mm, triangulares a estreitamente lanceoladas, ciliadas, indumento similar ao das brácteas. Corola lilás, 7-9 mm compr., internamente pubescente na base do tubo, externamente hirtela, tubo 3-5 mm compr., ligeiramente curvo, lábio superior ca. $4 \times 2 \mathrm{~mm}$, bilobado no ápice, lábio inferior ca. $5 \times 1,5-2 \mathrm{~mm}$. Filetes ca. $2 \mathrm{~mm}$ compr., anteras ca. 0,4 mm compr., tecas oblíquas, múticas. Estilete ca. $4 \mathrm{~mm}$ compr., glabro; disco nectarífero cupular, bilobado. Cápsula ca. $7 \mathrm{~mm}$ compr., hirsuta no ápice, com porção fértil fusiforme; sementes 4, ca. 1,5 mm diâm., suborbiculares, verrucosas, borda verrucosa a inteira.

Material examinado: BRASIL. BAHIA: Contendas do Sincorá, Serra do Sincorá para Corcovado, 
$13^{\circ} 55^{\prime} 03^{\prime \prime S} 41^{\circ} 08^{\prime} 11^{\prime \prime W}, 27-I V-2003$, fl., fr., bot., $A . C$. Mota et al. 5 (ALCB, SPF); Itiúba, $10 \mathrm{~km}$ da cidade, $10^{\circ} 39^{\prime 2} 28^{\prime \prime S} 39^{\circ} 44^{\prime} 16^{\prime \prime W}, 375$ m s.n.m., 28-I-2002, fr., bot., J.G.A. Nascimento \& T.S. Nunes 43 (HUEFS); Jacobina, Itaitu, entorno do lago de uma represa,

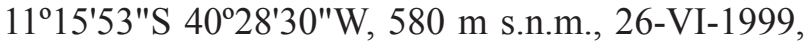
fr., bot., F. França et al. 3182 (HUEFS); Rio de Contas, $12,5 \mathrm{~km}$ de Rio de Contas estrada em direção

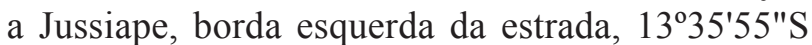
41ㄴ'4'12"W, 707 m s.n.m., 26-III-2008, fl., fr., bot., A.L.A. Côrtes et al. 75 (HUEFS); Rui Barbosa, Serra do Orobó, fazenda Santa Maria, $12^{\circ} 20^{\prime} 6^{\prime \prime S}$ $40^{\circ} 28^{\prime} 31^{\prime \prime} \mathrm{W}, 484$ m s.n.m., 20-XI-2004, fl., bot., L.P. Queiroz et al. 9981 (HUEFS).

Esta espécie foi corretamente identificada por Wasshausen (Wied, GZU 000250286) em Justicia, porém a combinação neste gênero não havia sido validamente publicada até aqui. Apesar de não ter indicado nenhum herbário no protólogo (Nees 1847a), Nees (1847b) apontou duas duplicatas dessa coleção, uma no herbário de Martius, atualmente incorporado ao herbário BR, e outra no herbário particular de Wied, e que possivelmente foi adquirida por Nees, podendo representar o material depositado no herbário GZU. Nees certamente examinou a coleção depositada em BR, que conta com a etiqueta original de Wied, a própria identificação de Nees (Rhytiglossa chamaedryoides N. et M., in sked) e um espécime completo, incluindo raízes, conforme descrita na obra original (diferente do material em GZU), justificando esta lectotipificação. Além disso, no protólogo, Nees (1847a) transcreveu a informação in sylvis ad Cabo Frio, Martio, indicada por ele na etiqueta do material depositado em GZU. Contudo, na etiqueta original de Wied (BR), há a clara indicação de März 1817. Neste período, Wied estava no final de sua viagem pelo Brasil, na região de Caatingas e matas secas do Estado da Bahia, um pouco antes de retornar para a Europa, não em Cabo Frio, Estado do Rio de Janeiro.

É uma pequena erva ereta, com espigas de flores opostas e imbricadas; a corola é pequena, lilás com estrias brancas no lobo central. Nos materiais observados, o cálice e as brácteas são alvo-hirsutos. É relacionada a Justicia genuflexa Nees, diferenciando-se principalmente pelo cálice quadripartido. Justicia chamaedryoides é endêmica do Estado da Bahia, sendo encontrada na borda de matas antropizadas, Floresce e frutifica, geralmente, entre novembro e junho.
6.6. Justicia chlamidocalyx A.L.A. Côrtes \& Rapini, Kew Bull. 66(3): 456, fig. 2 a-j. 2011

Figura 9

Arbusto, 1,5-2 m alt.; ramos quadrangulares, pubescentes a glabrescentes. Pecíolo 0,5-1,5 cm compr.; lâmina 3,5-9 × 1,8-4,5 cm, elíptica a ovada, esparsamente pubescente em ambas as faces, tricomas concentrados nas nervuras, ápice acuminado a atenuado, base brevemente decorrente. Inflorescência em espigas axilares e terminais; brácteas $1,3-1,5 \times 0,5-0,6 \mathrm{~cm}$, elípticas a ovadas, abaxialmente pubescentes a hirsutas, com tricomas concentrados nas nervuras, adaxialmente glabras a esparsamente hirsutas, ciliadas; bractéolas 1,2-1,3 × 0,4-0,3 cm, elípticas, indumento similar ao das brácteas. Cálice 1,1-1,5 cm compr., lacínias 5, 1-1,2 × 0,4-0,5 cm, lanceoladas, abaxialmente pubescentes a pilosas, adaxialmente com tricomas concentrados na nervura principal, ciliadas. Corola lilás, 2-3 cm compr., externamente pubescente com tricomas glandulares, internamente pilosa na base do tubo, glabra no restante, tubo 0,7-1 cm compr., curvo, lábio superior 1,3-2 $\times 0,6-1,3 \mathrm{~cm}$, bilobado no ápice, lábio inferior $1,4-2 \times 0,6-1,2 \mathrm{~cm}$. Filetes 1-1,8 cm compr., tecas a superior 2-2,4 mm compr., dorsalmente pubescente, a inferior 3-4 mm compr., apendiculada na base, tecas oblíquas. Estilete 4-7 cm compr., pubescente na base, disco nectarífero cupular. Cápsula 1-1,7 cm compr., pubérula, com porção fértil obovoide; sementes não vistas.

Material examinado: BRASIL. BAHIA: Caturama, Morro Branco, $13^{\circ} 17^{\prime} 45^{\prime \prime S} 42^{\circ} 12^{\prime} 01^{\prime \prime W}, 669$ m s.n.m., 6-VII-2007, fl., fr., A.A. Conceição et al. 2421 (HUEFS); Guanambi, estrada Guanambi-Carinhanha, $9 \mathrm{~km} \mathrm{~W}$ de Guanambi, $14^{\circ} 13^{\prime} 50^{\prime \prime S} 42^{\circ} 52^{\prime} 54^{\prime \prime} \mathrm{W}$, 620 m s.n.m., 15-IV-2002, fl., fr., F. França et al. 3781 (HUEFS); Irecê, $3 \mathrm{~km}$ de Irecê na estrada para Xique-Xique, 18-II-1981, fl., M. Socorro \& G. Ferreira 153 (ALCB); Morro do Chapéu, fazenda São João dos Brejões, rio Salitre, $11^{\circ} 16^{\prime} 01^{\prime \prime S}$

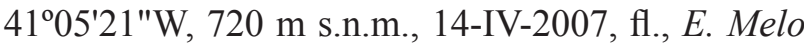
et al. 4694 (HUEFS); São Gabriel, fazenda Boa Sorte, $11^{\circ} 01^{\prime} \mathrm{S}, 39^{\circ} 04^{\prime} \mathrm{W}, 4-\mathrm{IV}-2009$, R. Machado et al. 152 (HUEFS); ibid., estrada para Bunina, $11^{\circ} 01^{\prime \prime S}, 39^{\circ} 04^{\prime} \mathrm{W}, 12-\mathrm{IV}-2009, R$. Machado et al. 250 (HUEFS).

Essa espécie é caracterizada pelas inflorescências axilares ou terminais com brácteas densas, geralmente ovadas e verdes, com a borda levemente enegrecida, a corola lilás, com lábios amplos, e os estames com 
tecas desiguais. O espécime encontrado em Caturama apresenta inflorescência com brácteas envelhecidas mais numerosas. Ocorre em Caatingas, comumente nas bordas. Em Morro do Chapéu é encontrada juntamente com Justicia angustissima. É endêmica do Estado da Bahia, florescendo de fevereiro a abril e iniciando a frutificação em abril.

6.7. Justicia comata (L.) Lam., Encycl. 1: 632. 1785. Figuras 6 o-u, 9

Erva, 20-50 cm alt.; ramos subquadrangulares a quadrangulares, glabros. Folhas sésseis, lâmina 2-7,5 $\times 0,5-1,5 \mathrm{~cm}$, estreitamente elíptica a lanceolada, glabra em ambas as faces ou estrigosa nas nervuras da face abaxial e margem, ápice agudo a atenuado, base cuneada a decorrente na base. Inflorescências paniculiformes com unidades de espigas secundas, 1-5 flores; brácteas ca. $1 \times 0,2 \mathrm{~mm}$, estreitamente triangulares, glabras ou hirtelas abaxialmente; bractéolas $0,6-0,9 \times 0,2-0,5 \mathrm{~mm}$, similares às brácteas. Cálice 2-2,5 mm compr., lacínias 5, 1,5-2 × 0,3-0,5 mm, lanceoladas, glabras ou abaxialmente hirtelas. Corola alvo-arroxeada, ca. $4 \mathrm{~mm}$ compr., glabra, tubo ca. $2 \mathrm{~mm}$ compr., ereto, lábio superior ca. $2 \times 1 \mathrm{~mm}$, bilobado no ápice, lábio inferior ca. $3 \times 1 \mathrm{~mm}$. Filetes ca. $1,5 \mathrm{~mm}$ compr., tecas a superior ca. $0,4 \mathrm{~mm}$, a inferior ca. $0,3 \mathrm{~mm}$, tecas oblíquas, múticas. Estilete ca. 2,3 $\mathrm{mm}$ compr., pubescente na base; disco nectarífero cupular. Cápsula 3-3,5 mm compr., hirtela, com porção fértil fusiforme, constrita entre as sementes; sementes 4 , ca. $1 \mathrm{~mm}$ diâm., orbiculares, tuberculadas, borda inteira.

Material selecionado: BRASIL. BAHIA: Feira da Mata, Rodovia Cocos/Feira da Mata, $23 \mathrm{~km}$ de Cocos, $14^{\circ} 15^{\prime} 04^{\prime \prime S} 44^{\circ} 22^{\prime} 10^{\prime \prime W}, 500$ m s.n.m., 17-IV-2001, fr., J.G. Jardim et al. 3625 (HUEFS).

Justicia comata tem aspecto graminoide e é caracterizada pela inflorescência paniculiforme com flores pequenas, ca. $4 \mathrm{~mm}$ compr. Está amplamente distribuída na América tropical, desde o sul do México e Costa Rica até a Bolívia, Paraguai, norte da Argentina e Nordeste do Brasil (Ezcurra 2002). No Estado da Bahia, ocorre tanto em lagoas temporárias da Caatinga como em regiões de Mata Atlântica. Habita lugares alagados em bordas de matas, mas também ambientes terrestres úmidos. Sua variabilidade morfológica em ambientes higrófilos e a ampla distribuição levou à criação de vários nomes para essa espécie, o que tem sido corrigido a partir de revisões regionais (Ezcurra 2002). Floresce e frutifica entre janeiro e junho.
6.8. Justicia congrua (Nees) Lindau in Engler \& Prantl, Nat. Pflanzenfam. 4(3b): 350. 1895.

Figuras 8 a-h, 9

Arbusto, ca. 1,5 cm alt.; ramos subquadrangulares, escabrosos. Pecíolo 1-1,5 cm compr.; lâmina 9-16 × (3,2-)7-7,5 cm, largamente elíptica, com pontuações glandulares e pequenos tricomas concentrados nas nervuras em ambas as faces, não ciliada, ápice arredondado a obtuso, base levemente decorrente. Inflorescência em espigas terminais; brácteas, 1-1,2 ×0,3-0,4 cm, espatuladas, vilosas a tomentosas; bractéolas ca. $1,1 \times 0,2 \mathrm{~cm}$, estreitamente espatuladas, indumento similar ao das brácteas. Cálice ca. 1,5 cm compr., lacínias 5, ca. 1,3 ×0,5 cm, lanceoladas, indumento similar ao das brácteas. Corola creme, ca. $3 \mathrm{~cm}$ compr., internamente com 2 tufos de tricomas próximo à base do tubo, externamente hirsuta, com tricomas glandulares; tubo ca. $1 \mathrm{~cm}$ compr., curvo, lábio superior ca. $2 \times 1,5 \mathrm{~cm}$, bilobado no ápice, lábio inferior ca. $2,1 \times 0,5 \mathrm{~cm}$. Filetes ca. 1,5 cm compr., tecas a superior ca. $3 \mathrm{~mm}$ compr., dorsalmente pubescente, a inferior ca. $4 \mathrm{~mm}$ compr., apendiculada na base, tecas oblíquas. Estilete ca. 2,5 cm compr., glabro; disco nectarífero cupular. Cápsula ca. $3 \mathrm{~cm}$ compr., levemente estriada, glabra, com porção fértil obovoide; sementes 2 , ca. $9 \mathrm{~mm}$ compr., suborbiculares a levemente cordiformes, lisas, borda inteira.

Material examinado: BRASIL. BAHIA: Abaíra, Mata de encosta, 13¹8'37"S 4151'42"W, 1-IV-1999, fl., fr., R.M. Harley et al. 54047 (HUEFS).

Material adicional examinado: BRASIL. s. loc., s.d., bot. e fl., F. Sellow s.n. (tipo B destruído - foto F!).

Justicia congrua caracteriza-se por ser um arbusto com folhas grandes, coriáceas e com pontuações glandulares em ambas as faces; produz espigas longas e eretas, com brácteas espatuladas e corola clara, com lábios amplos. Apresenta semelhança com Poikilacanthus bahiensis por possuir espiga ereta e terminal, brácteas espatuladas, corola com lábios amplos e reflexos, cápsulas grandes e sementes cordiformes e lisas. Porém, pode ser distinguida por apresentar brácteas sem tricomas glandulares na margem, a corola creme ( $v s$. rósea a roxa) e estames com as tecas desiguais e apendiculadas. Nees (1847a) descreveu essas duas espécies sob o gênero Adhatoda Nees, caracterizado principalmente pelas espigas axilares, brácteas e bractéolas grandes e cálice longo. É encontrada nos Estados do Espírito 

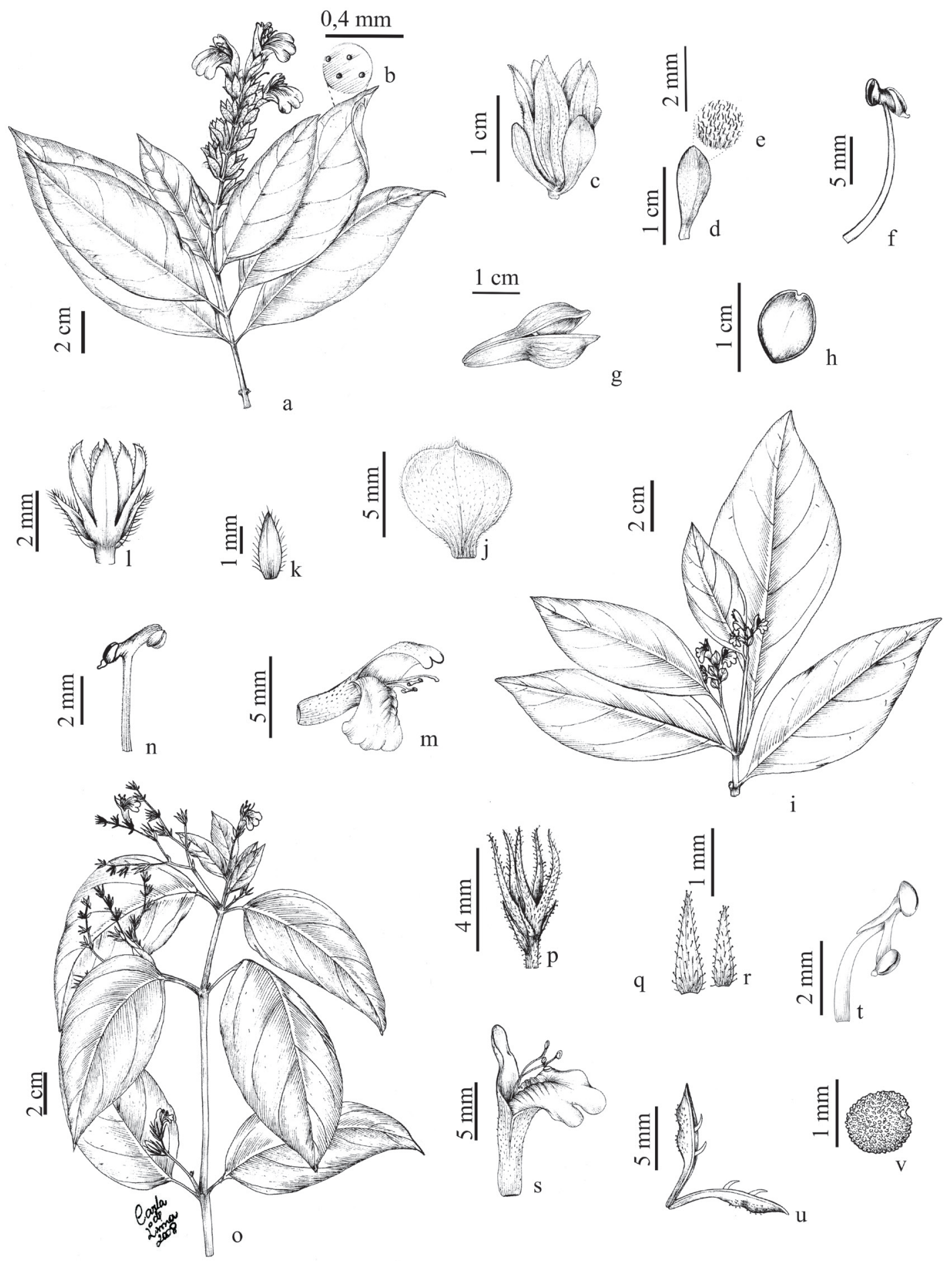

Figura 8. a-h. Justicia congrua. a. Ramo florido. b. Detalhe da folha, mostrando pontuações glandulares. c. Bráctea, bractéolas e cálice. d. Bráctea, face abaxial. e. Detalhe do indumento da face abaxial da bráctea. f. Estame. g. Fruto. h. Semente. i-n. J. cuneifolia. i. Ramo florido. j. Bráctea, face abaxial. k. Bractéola, face abaxial. 1. Bractéolas e cálice. m. Corola com estames e estilete. n. Estame. o-v. J. glaziovii. o. Ramo florido. p. Bráctea, bractéolas e cálice. q. Bráctea, face abaxial. r. Bractéola, face abaxial. s. Corola com estames. t. Estame. u. Fruto. v. Semente. (a-h. Harley 54047; i-n. Côrtes 117; o-t. Côrtes 32; u-v. Melo 5157).

Figure 8. a-h. Justicia congrua. a. Flowering branch. b. Leaf detail, showing gland punctuation. c. Bract, bracteoles and calyx. d. Bract, abaxial surface. e. Indumentum detail of abaxial bract surface. f. Stamen. g. Fruit. h. Seed. i-n. J. cuneifolia. i. Flowering branch. j. Bract, abaxial surface. k. Bracteole, abaxial surface. 1. Bracteoles and calyx. m. Corolla with stamens and style. n. Stamen. o-v. J. glaziovii. o. Flowering branch. p. Bract, bracteoles and calyx. q. Bract, abaxial surface. r. Bracteole, abaxial surface. s. Corolla with stamens. t. Stamen. u. Fruit. v. Seed. (a-h. Harley 54047; i-n. Côrtes 117; o-t. Côrtes 32; u-v. Melo 5157). 
Santo, Pernambuco e Bahia, onde ocorre em mata de encosta na Chapada Diamantina e também em áreas de transição entre a Caatinga e a Mata Atlântica, apresentando flores e frutos em abril.

6.9. Justicia cuneifolia Nees \& Mart. in WiedNeuwied, Nov. Actorum Acad. Caes. Leop.-Carol. Nat. Cur. 11(1): 58.1823.

Figuras 8 i-n, 9, 17 h

Arbusto densamente ramificado, ca. $60 \mathrm{~cm}$ alt.; ramos subquadrangulares a quadrangulares, glabrescentes. Pecíolo 0,5-1 cm compr.; lâmina 5,7-9 × 2,5-3,5 cm, elíptica, glabras ou com tricomas pequenos nas nervuras principais e laterais de ambas as faces, ápice agudo a acuminado, às vezes caudado, base decorrente. Inflorescência em espigas axilares e terminais; brácteas 6-8 × 5-6 mm, orbiculares, unguiculadas na base, adaxialmente hirtelas, com tricomas concentrados na nervura principal, abaxialmente glabras, ciliada; bractéolas $2-3 \times$ ca. $1 \mathrm{~mm}$, lanceoladas, glabras em ambas as faces, ciliadas. Cálice 3,2-4 mm compr., lacínias 5, 2,7-3,4 × ca. $0,8 \mathrm{~mm}$, lanceoladas, glabras, esparsamente ciliadas. Corola creme com máculas roxas, ca. $1 \mathrm{~cm}$ compr., internamente com tricomas nas nervuras, externamente hirtela a hispídula, tubo 4-5 mm compr., ereto, lábio superior 5-6 × 2-3 mm, bífido no ápice, lábio inferior $4-4,2 \times$ ca. $5 \mathrm{~mm}$. Filetes ca. $6 \mathrm{~mm}$ compr., anteras ca. $1 \mathrm{~mm}$ compr., tecas superpostas, as inferiores apendiculadas na base. Estilete ca. $8 \mathrm{~mm}$ compr., basalmente pubescente; disco nectarífero cupular. Cápsula não vista.

Material examinado: BRASIL. 1836, J. Blanchet 2395 (síntipo P - foto!); via Felisbertia, XII.1834, M.A.P. Wied-Neuwied s.n. (síntipo BR n.v. - foto GZU!); BAHIA: Jequié, Serra do Brejo, estrada de Mandacaru para Brejo Novo (rua do estádio da cidade), fazenda do Sr. Francisco Brito (Flor), 1356'49"S 4006'40”W, 600-700 m s.n.m., 7-IX-2008, fl., bot., A.L.A. Côrtes et al. 117 (HUEFS).

Justicia cuneifolia é facilmente distinguida por ser um arbusto bem ramificado, baixo, com inflorescências terminais, brácteas verdes, orbiculares, corola pequena, branca com máculas roxas no lobo central e tecas superpostas. No Estado da Bahia, é encontrada em matas de cipó, geralmente em altitudes de 600 a $700 \mathrm{~m}$. É sintópica com outras espécies de Acanthaceae como: Herpetacanthus magnobracteolatus, Stenandrium sp. e Ruellia sp. Foi encontrada com flores em setembro.
6.10. Justicia glaziovii Lindau, Bull. Herb. Boiss. 3(9): 483. 1895.

Figuras $8 \mathrm{o}-\mathrm{v}, 9,17 \mathrm{i}$

Arbusto ereto, eventualmente escandente, ca. $80 \mathrm{~cm}$ alt.; ramos subcilíndricos, quando jovens pubescentes a pilosos. Pecíolo 0,2-1,5 cm compr.; lâmina 2,7-9 × 1,3-3 cm, elíptica a ovada, adaxialmente esparsamente hirsuta, abaxialmente hirsuta, ou com tricomas concentrados nas nervuras, ápice agudo, base decorrente. Inflorescência paniculiforme, com unidades de espigas secundas, 1-3 flores; brácteas $1-2 \times$ ca. $0,5 \mathrm{~mm}$, lineares a estreitamente triangulares, hirtelas em ambas as faces ou glabras adaxialmente, escassos tricomas glandulares; bractéolas similares às brácteas. Cálice 3-4,5 mm compr., lacínias 5, 2,5-4 $\times$ 4-5 mm, lineares a estreitamente triangulares, adaxialmente esparsamente hirsutas, abaxialmente hirtelas, com tricomas glandulares. Corola lilás, alva no tubo, 0,9-1,5 cm compr., internamente hispídula nas nervuras do tubo, externamente hirtela a hispídula, tubo 3-6 mm compr., ereto, lábio superior 5-8 $\times 4-5 \mathrm{~mm}$, ápice apiculado, lábio inferior ca. $8 \times 6 \mathrm{~mm}$. Filetes ca. $7 \mathrm{~mm}$ compr., tecas superiores ca. $1 \mathrm{~mm}$ compr., dorsalmente pubérula, a inferior 0,5-0,7 mm compr., tecas superpostas, a inferior apendiculada na base, com apêndice filiforme próximo à teca superior. Estilete ca. $6 \mathrm{~mm}$ compr., glabro; disco nectarífero cupular. Cápsula ca. $1 \mathrm{~cm}$ compr., pubérula a pubescente, com tricomas glandulares, com porção fértil fusiforme, constrita entre as sementes; sementes 4 , ca. $1 \mathrm{~mm}$ compr., suborbiculares, tuberculadas, borda tuberculada.

Material selecionado: BRASIL. BAHIA: Castro Alves, 26-VIII-1994, fl., fr. e bot., C.A.L. Carvalho 70 (HUEFS); Feira de Santana, Distrito de Ipuaçu, Estrada do Feijão, fazenda Chapada do Senhor Morais, $12^{\circ} 13^{\prime} \mathrm{S} 39^{\circ} 4^{\prime} \mathrm{W}, 5-\mathrm{IX}-2007$, fl., bot., A.L.A. Côrtes et al. 32 (HUEFS); ibid, $12^{\circ} 15^{\prime} 22^{\prime \prime S} 39^{\circ} 4^{\prime} 58^{\prime \prime} \mathrm{W}$, 11-X-2007, fl., fr., E. Melo et al. 5157 (HUEFS); Ipirá, fazenda Recreio, Estrada do Feijão, Km 43, 12²2'S $38^{\circ} 41^{\prime} \mathrm{W}, 4-\mathrm{X}-1986$, fl., fr., bot., L.P. Queiroz et al. 970 (HUEFS).

Justicia glaziovii caracteriza-se pela inflorescência paniculiforme com flores pequenas, alvo-arroxeadas, lábios amplos e reflexos, e tecas desiguais, superpostas. Assemelha-se a J. xipotensis em relação ao hábito, folhas, inflorescências, posição das anteras e indumento. Porém, a corola branca e lilás ( $v s$. vermelha), com 0,9-1,5 cm compr. 
(vs. 2,5-3,3 cm compr.), os estames com ca. $7 \mathrm{~mm}$ compr. (vs. 1-1,5 cm compr.) e o estilete com ca. $6 \mathrm{~mm}$ compr. (vs. ca. $2,5 \mathrm{~cm}$ compr.) são características que facilmente distinguem essas duas espécies. Era conhecida somente no sul do Brasil, oeste da Bolívia e Nordeste do Paraguai (Ezcurra 2002), mas ocorre também nos Estados do Mato Grosso do Sul e Bahia. É encontrada geralmente na borda de matas ou em Caatingas, ocorrendo também fora dos limites do Semiárido. Floresce de agosto a janeiro, frutificando geralmente no verão.

6.11. Justicia harleyi Wassh., Proc. Biol. Soc. Washington 105(4): 669. 1992.

Figuras $10 \mathrm{a}-\mathrm{h}, 11$

Arbusto, ca. $50 \mathrm{~cm}$ alt.; ramos cilíndricos, pubescentes. Pecíolo 1-2 mm compr.; lâmina 4,7-8,5 × 2,5-4 cm, elíptica, esparsamente hirsuta em as ambas faces, com tricomas concentrados nas nervuras, ápice agudo a apiculado, base longamente decorrente. Inflorescência em espigas axilares e terminais; brácteas 7-10 × ca. $1 \mathrm{~mm}$, lanceoladas, esparsamente híspidas, abaxialmente com tricomas glandulares, ciliadas; bractéola $1,7-8 \times$ ca. $0,7 \mathrm{~mm}$, lanceolada, no mais, similar às brácteas. Cálice ca. $8 \mathrm{~mm}$ compr.,

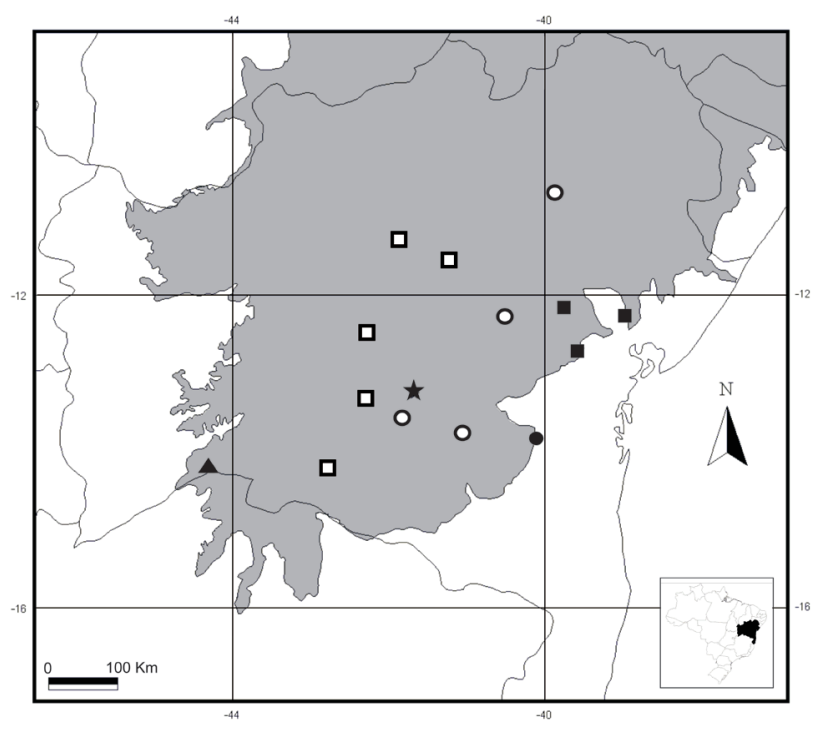

Figura 9. Distribuição de Justicia chamaedryoides (O), J. chlamidocalyx (ם), J. comata $(\boldsymbol{\Delta})$, J. congrua ( $\boldsymbol{\star})$, J. cuneifolia (•) e J. glaziovii (ם) no Semiárido do Estado da Bahia, Brasil (área cinza).

Figure 9. Distribution of Justicia chamaedryoides (O), J.

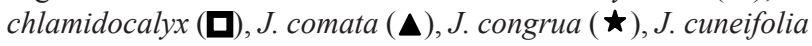
$(\mathbf{)})$, and J. glaziovii ( $\mathbf{\square})$ in the Semiarid of Bahia State, Brazil (gray area). lacínias 4, 8-11 × ca. 0,3 mm, lineares, no mais, similar às brácteas. Corola lilás, 2-3 cm compr., internamente glabra, externamente hirtela, tubo 1,7-2 cm compr., ereto, lábio superior $4-11 \times$ ca. $3 \mathrm{~mm}$, bilobado no ápice, lábio inferior 3-9 × ca. $4 \mathrm{~mm}$. Filetes 2-7 mm compr., tecas a superior 1-1,7 mm compr., a inferior 0,5-1 $\mathrm{mm}$ compr., apendiculada na base, tecas superpostas. Estilete ca. 2 cm compr., glabro; disco nectarífero cupular bilobado. Cápsula 6-7 mm compr., pubérula, com porção fértil fusiforme, constrita entre as sementes; sementes 4, ca, 1,7 mm diâm., arredondadas, tuberculadas, borda tuberculada.

Material examinado: BRASIL. BAHIA: Caturama, entre Caieiras e Tamboril, $13^{\circ} 15^{\prime} 16^{\prime \prime} \mathrm{S} 42^{\circ} 12^{\prime} 32^{\prime \prime} \mathrm{W}$, 740 m s.n.m., 4-VII-2007, fl., fr., A.A. Conceição et al. 2380 (HUEFS); Correntina, $25 \mathrm{~km}$ norte de Correntina, ao longo da estrada para Inhaúmas, $13^{\circ} 13^{\prime} \mathrm{S} 44^{\circ} 38^{\prime} \mathrm{W}, 29-\mathrm{IV}-1980$, fl., fr., R.M. Harley et al. 21923 (CEPEC); Ibipitanga, estrada Ibipitanga a Mocambo, 12 $39^{\prime} 06^{\prime \prime S} 42^{\circ} 17^{\prime} 44^{\prime \prime} \mathrm{W}, 3-\mathrm{VII}-2007$, fl., fr., A.A. Conceição et al. 2312 (HUEFS).

É reconhecida pelas espigas axilares, estreitas, com brácteas e bractéolas aproximadamente do mesmo tamanho do cálice, e corola com lábios estreitos. Apresenta semelhança com Chaetothylax eranthemanthus Rizzini, que se diferencia pelas brácteas menores (1-3 mm compr.), folhas oblongas 4-7 × 1,7-2,7 cm, com ápice atenuado e margem crenada (Wasshausen 1992). Justicia harleyi é endêmica do Estado da Bahia, ocorrendo em Caatingas, geralmente na beira de estradas. Encontrada com flores e frutos em julho.

6.12. Justicia jacuipensis A.L.A. Côrtes \& Rapini, Kew Bull. 66(3): 457, fig. 2 k-t. 2011. Figura 11

Arbusto, ca. $40 \mathrm{~cm}$ alt.; ramos quadrangulares, glabros a pubérulos. Pecíolo ca. $1 \mathrm{~mm}$ compr.; lâmina 0,8-1,5 × 0,5-1 cm, ovada, glabra em ambas as faces, com tricomas esparsos nas nervuras e esparsamente hirsuta na margem, ápice obtuso a agudo, base obtusa. Inflorescência em espiga; bráctea 0,9-1 × 0,6-0,8 cm, ovadas, glabras, hirsutas na margem; bractéolas ca. $2 \times 0,1 \mathrm{~mm}$, lineares, glabras. Cálice ca. $4 \mathrm{~mm}$ compr., lacínias 5 , ca. $3 \times 0,2 \mathrm{~mm}$, triangulares, esparsamente hirtelas. Corola lilás com manchas alvas, ca. $2 \mathrm{~cm}$ compr., internamente glabra, externamente pubescente, tubo ca. 1,2 cm compr., ereto, lábio 

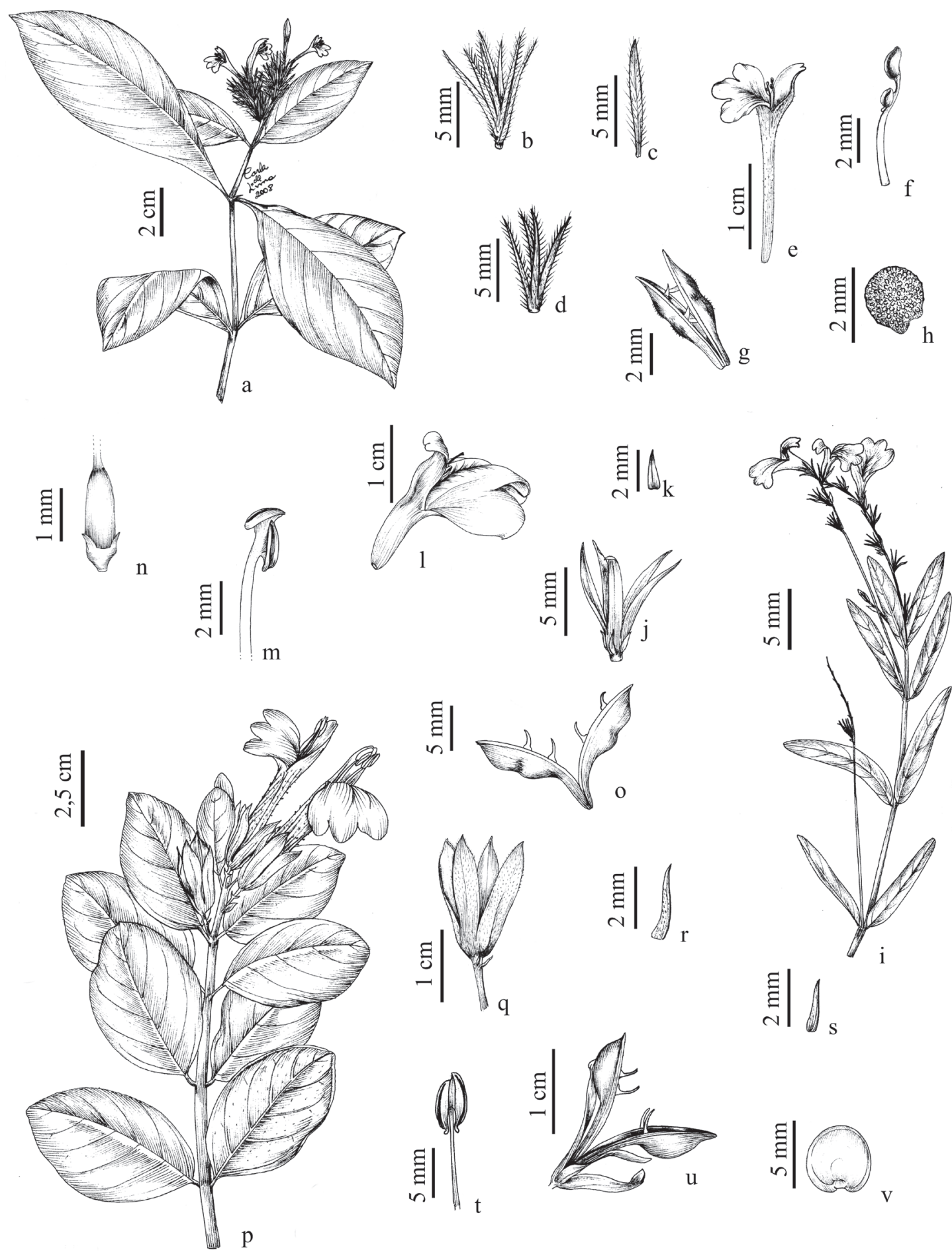

Figura 10. a-h. Justicia harleyi. a. Ramo florido. b. Bráctea, bractéolas e cálice. c. Bráctea, face abaxial. d. Cálice. e. Corola com estames. f. Estame. g. Fruto. h. Semente. i-o. J. laevilinguis. i. Ramo florido. j. Bráctea, bractéolas e cálice. k. Bráctea, face abaxial. 1. Corola com estilete. m. Estame. n. Disco nectarífero e ovário. o. Fruto. p-v. J. lepida. p. Ramo florido. q. Bráctea, bractéola e cálice. r. Bráctea, face abaxial. s. Bractéola, face abaxial. t. Estame. u. Fruto com cálice. v. Semente. (a-h. Conceição 2380; i-o. Harley 28478; p-v. Cardoso 656).

Figure 10. a-h. Justicia harleyi. a. Flowering branch. b. Bract, bracteoles and calyx. c. Bract, abaxial surface. d. Calyx. e. Corolla with stamens. f. Stamen. g. Fruit. h. Seed. i-o. J. laevilinguis. i. Flowering branch. j. Bract, bracteoles and calyx. k. Bract, abaxial surface. 1. Corolla with style. m. Stamen. n. Nectariferous disk and ovary. o. Fruit. p-v. J. lepida. p. Flowering branch. q. Bract, bracteole and calyx. r. Bract, abaxial surface. s. Bracteole, abaxial surface. t. Stamen. u. Fruit with calyx. v. Seed. (a-h. Conceição 2380; i-o. Harley 28478; p-v. Cardoso 656). 
superior ca. $4 \times 2,5 \mathrm{~mm}$, bilobado no ápice, lábio inferior 5-6 $\times$ 4-4,3 mm. Filetes ca. $4 \mathrm{~mm}$ compr., tecas a superior ca. $1,3 \mathrm{~mm}$ compr., a inferior ca. $1 \mathrm{~mm}$ compr., oblíquas, múticas. Estilete ca. 1,2 cm compr., pubescente na base; disco nectarífero cupular. Cápsula ca. $6 \mathrm{~mm}$ compr., glabra, com porção fértil fusiforme; sementes 4 , ca. $3 \mathrm{~mm}$ diâm., suborbiculares, tuberculadas, borda tuberculada.

Material examinado: BRASIL. BAhIA: Feira de Santana, Rod. Feira-Rio de Janeiro, Km 8, margem do rio Jacuípe, 19-II-1981, fl., bot., A.M. Carvalho et al. 573 (CEPEC).

É reconhecida pelo pequeno porte, as folhas pequenas, com até 1,5 cm compr., ovadas, as brácteas ovadas, com até $1 \mathrm{~cm}$ compr., e a corola lilás com mancha branca, tubo estreito com lábios pequenos e curtos. Foi encontrada na margem do rio Jacuípe, em vegetação de Caatinga. Endêmica do Estado da Bahia, possivelmente está ameaçada de extinção, pois a área onde foi coletada encontra-se inundada pela represa Pedra do Cavalo e seus arredores vastamente antropizados. Foi encontrada com flores em fevereiro.

6.13. Justicia laevilinguis (Nees) Lindau in Engler,

Bot. Jahrb. Syst. 19, Beibl. 48: 20. 1894.

Figuras 10 i-o, 11, 18 a

Erva prostrada, 40-60 cm alt.; ramos quadrangulares, glabros. Pecíolo até $2 \mathrm{~mm}$ compr.; lâmina 1,5-5,5 × 0,3-1,3 cm, oblonga, obovada ou lanceolada, ambas as faces glabras, ápice agudo a arredondado, base truncada a obtusa. Inflorescência em espigas secundifloras, com 1 flor; brácteas $1-2 \times 0,5-1 \mathrm{~mm}$, triangulares, glabras em ambas as faces; bractéolas 1-2 $\times$ ca. 0,5 mm, lanceoladas a triangulares, no mais similar à bráctea. Cálice 7-9 mm compr., lacínias 5, 6-8 × ca. $1 \mathrm{~mm}$, lineares, glabras em ambas as faces. Corola roxa a lilás com máculas alvas no centro, 1,4-2 cm compr., internamente glabra, externamente pubérula, com tricomas glandulares, tubo 7-9 mm compr., curvo, lábio superior $7-8 \times$ ca. $3 \mathrm{~mm}$, bilobado no ápice, lábio inferior 0,8-1,4 $\times$ 0,2-0, $4 \mathrm{~cm}$. Filetes ca. $6 \mathrm{~mm}$ compr., anteras ca. $2 \mathrm{~mm}$ compr., tecas oblíquas, múticas. Estilete ca. 1,5 cm compr., glabro; disco nectarífero cupular lobado. Cápsula 1,2-1,5 cm compr., glabra com porção fértil fusiforme, constrita entre as sementes; sementes 4, ca. 4 mm diâm., suborbiculares, tuberculadas, borda lacerada.
Material selecionado: BRASIL. BAHIA. Anajé, Serra dos Pombos, 14-V-1983, fr., G. Hatschbach 46376 (MBM); Bom Jesus da Lapa, $10 \mathrm{~km}$ E na estrada para Morrão, 13¹0'11"S 4317'03"W, 9-II-2000, fl., bot., L.P. Queiroz et al. 5755 (HUEFS); Feira de Santana, Campus da UEFS, $12^{\circ} 15^{\prime} \mathrm{S} 38^{\circ} 58^{\prime} \mathrm{W}, 6-\mathrm{V}-1983$, fl., fr., bot., L.R. Noblick \& M.S. Lemos 2604 (HRB, HUEFS); Itaberaba, margem do rio Paraguaçu, divisa com Iaçu, 4-VI-1995, fr., bot., F. França et al. 1224 (HUEFS); Jacobina, Catuaba, $11^{\circ} 10^{\prime} 22^{\prime \prime S} 40^{\circ} 32^{\prime} 44^{\prime \prime W}$, 728 m s.n.m., 4-VII-1996, bot., A.M. Giulietti et al. 3394 (ALCB, HUEFS); Milagres, $11 \mathrm{~km}$ antes do entroncamento para Iaçu, 10-II-1997, bot., A.M. Giulietti et al. 5473 (ALCB, HUEFS); Santa Bárbara, fazenda Pojuca, 1155'53"S 38 58'44"W, 26-XI-2005, fl., fr., bot., E. Melo et al. 4211 (HUEFS). ibid,

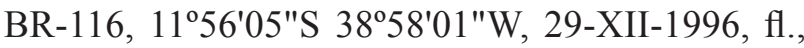
R.M. Harley \& A.M. Giulietti 28478 (HUEFS).

Material adicional examinado: BRASIL. s. loc., s.d., bot., fl., F. Sellow s.n. (tipo B destruído - foto F!).

Justicia laevilinguis habita ambientes palustres e é caracterizada pela inflorescência secundiflora, com amplas flores roxas com linhas brancas na fauce. Estudos recentes têm incluído vários sinônimos nesta espécie, até mesmo de táxons designados a gêneros distintos por Nees (1847a). A espécie é reportada para a Colômbia, Venezuela, Peru, Bolívia, Uruguai, Paraguai, nordeste da Argentina, sul do Brasil, além dos Estados da Bahia e Mato Grosso do Sul (Ezcurra 2002), tendo as folhas mais estreitas, ca. $2 \mathrm{~mm}$ de larg., no Mato Grosso do Sul. É comum em beira de lagoas, sobre solos arenoso-argilosos no semiárido da Bahia. Floresce do verão ao inverno, frutificando principalmente no inverno.

6.14. Justicia lepida (Moric.) Wassh., Baileya 19: 3. 1973. Figuras $10 \mathrm{p}-\mathrm{v}, 11,18 \mathrm{~b}$

Arbusto, 0,5-2 m alt.; ramos cilíndricos, pubérulos ou velutinos a tomentelos. Pecíolo 2-6 mm compr.; lâmina, 2,3-8,5 × 1-4 cm, elíptica ou obovada a ovada, ambas as faces escabra, com tricomas concentrados nas nervuras e ao longo das margens, ápice arredondado a agudo, base cuneada. Inflorescência em racemos axilares, 1-3 flores; bráctea 2-3 $\times$ ca. 0,3 mm, lineares, escabras em ambas as faces; bractéolas 2-3 $\times$ ca. $0,2 \mathrm{~mm}$, lineares, no mais similar às brácteas. Pedicelo ca. $1 \mathrm{~mm}$ compr. Cálice ca. 1,6 cm compr., lacínias 4, 1,2-2 × 0,2-0,4 cm, 
lanceoladas, pubescentes a escabras, raramente longamente ciliadas. Corola vermelha ou rósea, 4,5-5 cm compr., internamente glabra a puberulenta, externamente hirtela, com tricomas eglandulares e glandulares, tubo $1,7-2,5 \mathrm{~cm}$ compr. ereto, lábio superior $2-2,5 \times$ ca. $0,6 \mathrm{~cm}$, bilobado no ápice, lábio inferior 2-2,5 $\times 0,4-0,5 \mathrm{~cm}$. Filetes ca. 2,5 cm compr., tecas superior ca. $4 \mathrm{~mm}$ compr., a inferior ca. $5 \mathrm{~mm}$ compr., paralelas, apendiculadas na base. Estilete ca. $4 \mathrm{~cm}$ compr., glabro; disco nectarífero anular. Cápsula ca. $2 \mathrm{~cm}$ compr., glabra, com porção fértil obovoide; sementes 4, ca. 5 mm diâm., arredondadas, lisas, borda inteira.

Material selecionado: BRASIL. BAHIA: Carnaíba, IV-1994, fl., M. Sobral \& W. Ganev 7572 (HUEFS, MBM); Jacobina, Serra do Brite, $11^{\circ} 09^{\prime} 07^{\prime \prime S}$ 4000'41"W, 23-VIII-1980, fl., fr., R.P. Orlandi 195 (CEPEC, HRB); Jaguarari, Serra dos Morgados, $10^{\circ} 08^{\prime} \mathrm{S} 40^{\circ} 13^{\prime} \mathrm{W}, 25-\mathrm{VI}-2005$, fl., R.F. Souza-Silva \& A. Rapini 32 (HUEFS); Lençóis, Serra da Chapadinha, 12²7'02"S 4127'03"W, 920 m s.n.m., 23-II-1995, fl., E. Melo et al. 1691 (ALCB, HRB, HUEFS); Miguel Calmom, Piemonte da Chapada, $11^{\circ} 22$ '20"S 40³1'07"W, 1.144 m s.n.m., 17-VI-2006, fl., bot., M.L. Guedes et al. 12097 (ALCB); Morro do Chapéu, $4 \mathrm{~km} \mathrm{SW}$ da cidade, Torre de Morro do Chapéu,

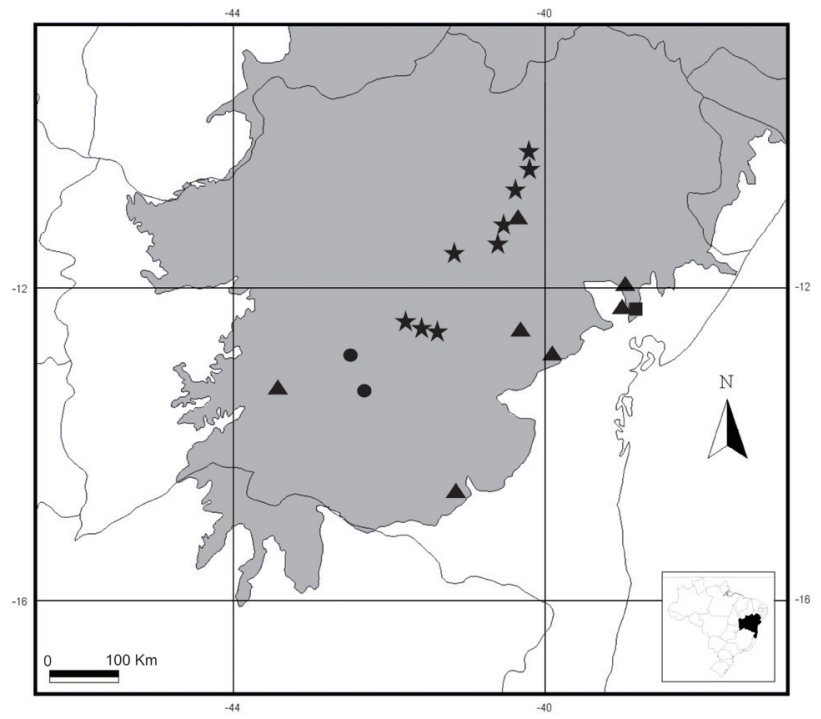

Figura 11. Distribuição de Justicia harleyi (৩), J. jacuipensis $(\boldsymbol{\square})$, J. laevilinguis $(\mathbf{\Delta})$ e J. lepida ( $\star$ ) no Semiárido do Estado da Bahia, Brasil (área cinza).

Figure 11. Distribution of Justicia harleyi (•), J. jacuipensis $(\boldsymbol{\square})$, J. laevilinguis $(\boldsymbol{\Delta})$ and J. lepida $(\boldsymbol{\star})$ in the Semiarid of Bahia State, Brazil (gray area). estrada para Utinga, $11^{\circ} 35^{\prime} \mathrm{S} 41^{\circ} 11^{\prime} \mathrm{W}, 1.150 \mathrm{~m}$ s.n.m., 2-VI-1980, fl., R.M. Harley et al. 22989 (CEPEC); Palmeiras, Pai Inácio, 12²7'20"S 4127'15"W, 1.080 m s.n.m., 25-X-1994, fl., fr., A.M. Carvalho et al. 993 (ALCB, HUEFS); Pindobaçu, estrada para Garimpo, Bairro Novo, 1045'12"S 40²3'05"W, 715 m s.n.m., 12-VIII-1999, fl., fr., E.B. Miranda et al. 148 (HUEFS); Seabra, Serra do Bebedor, $4 \mathrm{~km} \mathrm{~W}$ de Lagoa da Boa Vista na entrada para Gado Bravo, 12¹7'8"S 4149'36"W, 1.200 m s.n.m., 22-VI-1993, fl., fr., L.P. Queiroz \& N.S. Nascimento 3337 (HUEFS); Senhor do Bonfim, Serra de Santana, $10^{\circ} 22^{\prime} 31^{\prime \prime S} 40^{\circ} 12^{\prime} 28^{\prime \prime} \mathrm{W}, 818$ m s.n.m., 12-VII-2005, fl., fr., D.B.O.S. Cardoso et al. 656 (HUEFS).

Justicia lepida é caracterizada pela folha com lâmina elíptica a ovada, geralmente coriácea, com margem levemente revoluta, pelo cálice com lacínias longas, e pela corola geralmente vermelha e relativamente grande (4,5-5 cm compr.), com lobos amplos e arredondados. É endêmica do Semiárido do Estado da Bahia, ocorrendo em campos rupestres, matas e caatingas arbustivas com solos pedregosos e arenosos. Floresce praticamente o ano todo.

6.15. Justicia simonisia V.A.W.Graham, Kew Bull. 43(4): 606. 1988.

Figuras $12 \mathrm{a}-\mathrm{h}, 13,18 \mathrm{c}$

Arbusto escandente, $50-80 \mathrm{~cm}$ alt.; ramos subcilíndricos, glabros a esparsamente hirsutos. Pecíolo 5-7 mm compr.; lâmina 3-10,5 × 1-4,4 cm, elíptica, glabras a esparsamente hirsutas, com tricomas concentrados nas nervuras em ambas as faces, ápice agudo a atenuado, base decorrente. Inflorescência em espigas axilares e terminais; brácteas 1,8-2,4 × 0,3-0,4 cm, lanceoladas, hirtelas ou hirsutas a híspidas em ambas as faces, curta a longamente ciliadas com tricomas 1-2 mm compr.; bractéolas 1,7-2 × ca. 0,15 cm, estreitamente lanceoladas, no resto similar às brácteas. Cálice 1,5 cm compr., lacínias 5, ca. 1,3-1,4 × 0,3-0,4 cm, lanceoladas, hirtelas, curta a longamente ciliadas, com tricomas 1-2 mm compr. Corola lilás, ca. 4 cm compr., puberulenta, exceto internamente nos lábios, tubo ca. 2,9 cm compr., curvo, lábio superior ca. 1,2 $\times 1$, bilobado no ápice, lábio inferior ca. $1,2 \times 0,7 \mathrm{~cm}$. Filetes 6-7 mm compr., anteras 2-3 mm compr., tecas superpostas, ambas apendiculadas na base. Estilete ca. 3,5 cm compr., glabro; disco nectarífero anular, bilobado. Cápsula ca. $1 \mathrm{~cm}$ compr., pubescente, com porção fértil obovoide; semente não vista. 


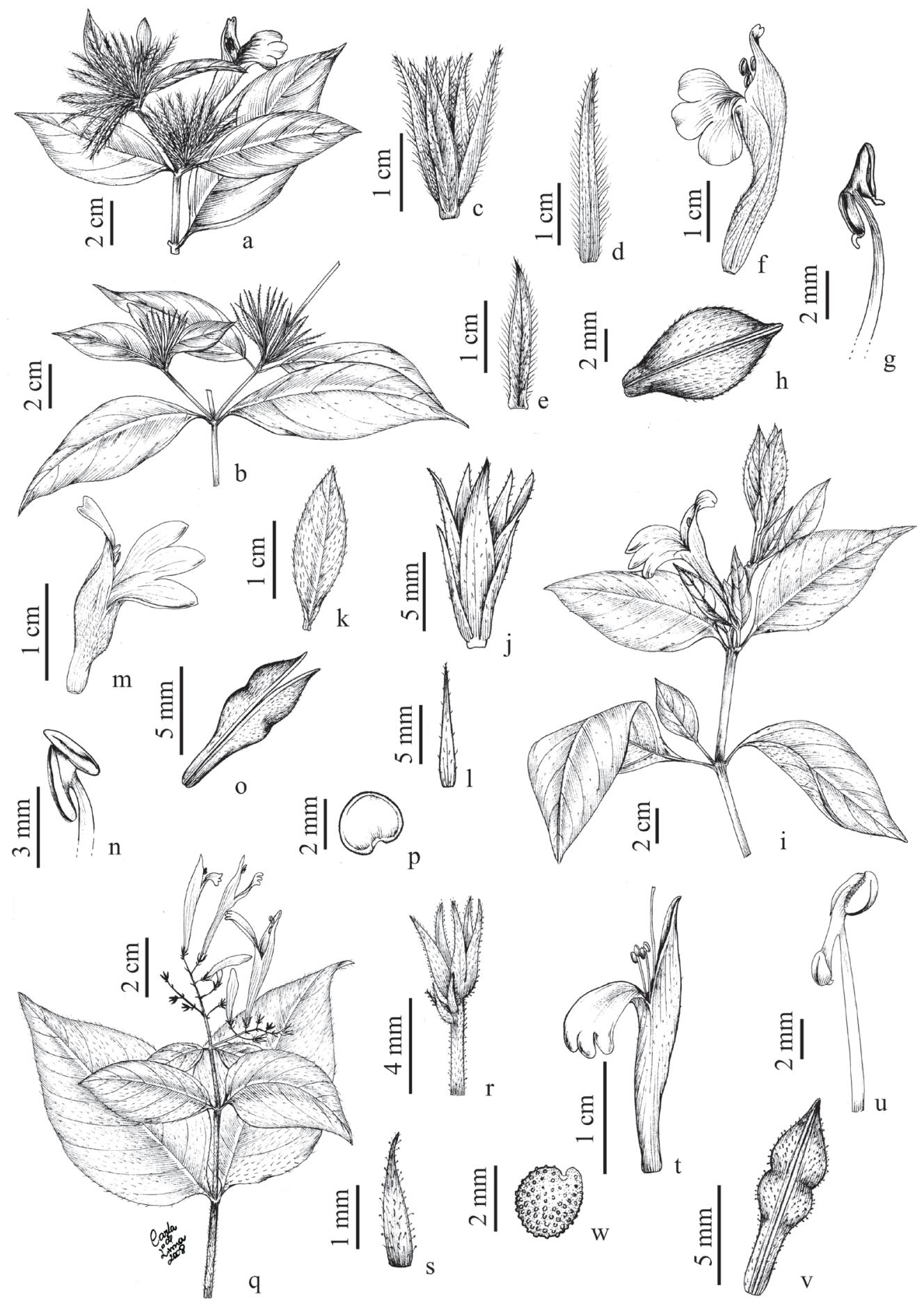

Figura 12. a-h. Justicia simonisia. a. Ramo florido, ciliada. b. Ramo florido, esparsamente ciliada. c. Bráctea, bractéolas e cálice. d. Bráctea, face abaxial. e. Bractéola, face abaxial. f. Corola com estame. g. Estame. h. Fruto. i-p. J. thunbergioides. i. Ramo florido. j. Bractéolas e cálice. k. Bráctea, face abaxial. 1. Bractéola, face abaxial. m. Corola. n. Antera. o. Fruto. p. Semente. q-w. J. xipotensis. q. Ramo florido. r. Bráctea, bractéolas e cálice. s. Bráctea, face abaxial; t. Corola com estames e estilete. u. Estame. v. Fruto. w. Semente. (a, c-h. Côrtes 91; b. Ribeiro 406; i-p. Côrtes 74; q. Conceição 1963; r-w. Hatschbach 44147).

Figure 12. a-h. Justicia simonisia. a. Flowering branch, ciliate. b. Flowering branch, slightly ciliate. c. Bract, bracteoles and calyx. d. Bract, abaxial surface. e. Bracteole, abaxial surface. f. Corolla with stamen. g. Stamen. h. Fruit. i-p. J. thunbergioides. i. Flowering branch. j. Bracteoles calyx. k. Bract, abaxial surface. 1. Bracteole, abaxial surface. m. Corolla. n. Anther. o. Fruit. p. Seed. q-w. J. xipotensis. q. Flowering branch. r. Bract, bracteoles and calyx. s. Bract, abaxial surface; t. Corolla with stamens and style. u. Stamen. v. Fruit. w. Seed. (a, c-h. Côrtes 91; b. Ribeiro 406; i-p. Côrtes 74; q. Conceição 1963; r-w. Hatschbach 44147). 
Material examinado: BRASIL. BAHIA: Urandi, estrada de terra para Licínio de Almeida, $14^{\circ} 44^{\prime} 53,9^{\prime \prime S}$ 423'ㄴ, ${ }^{\circ}$ "W, 873 m s.n.m., 21-IV-2008, fl., A.L.A. Côrtes et al. 91 (HUEFS); ibid, estrada para fazenda Palmeira, ca. $10 \mathrm{~km}$ de Urandi, 14\%46'30"S $42^{\circ} 25^{\prime} 45^{\prime \prime W}, 843$ m s.n.m., 9-IV-2002, fl., T. Ribeiro et al. 406 (HUEFS).

Material adicional examinado: BRASIL. EsPÍRITO SANTO: Colatina, Aldea Velha, 1824, fl., M.A.P. WiedNeuwied s.n. (tipo B destruído - foto F!)

É reconhecida por apresentar uma espiga congesta, com brácteas e bractéolas longamente lanceoladas aproximadamente do tamanho do cálice e com tricomas longos ao longo da margem. Alguns materiais, no entanto, podem apresentar esses tricomas bem menores ou quase ausentes. Ocorre também no Estado do Espírito Santo; na Bahia, é encontrada na Caatinga, em locais bastante áridos, geralmente na beira de estradas, com flores e frutos em abril.

6.16. Justicia thunbergioides (Lindau) Leonard, Contr. Sci. Los Angeles County Mus. 32: 10. 1959. Figuras $12 \mathrm{i}-\mathrm{p}, 13,18 \mathrm{~d}$

Arbusto, 0,3-1,5 m alt.; ramos subquadrangulares, puberulentos a glabrescentes, com tricomas nas estrias. Pecíolo 0,6-3,5 cm compr.; lâmina 5-11 × 3-6 cm, elíptica a ovada, esparsamente hirsuta a esparsamente pubescente adaxialmente, eventualmente com tricomas concentrados nas nervuras, abaxialmente pubescente, ápice agudo a atenuado, base arredondada a levemente decorrente. Inflorescência em espigas secundifloras axilares e terminais ou solitárias, com 1-2 flores; brácteas foliáceas, 0,7-3 × 0,7-1 cm, ovadas a elípticas, estrigosas a esparsamente pubescentes em ambas as faces, com tricomas concentrados nas nervuras, tricomas adpressos na margem; bractéolas 0,7-1,25 × ca. $0,1 \mathrm{~mm}$, lanceoladas a lineares, no mais, similar às brácteas. Cálice 1-1,2 cm compr., lacínias $5,0,9-1,4 \times 0,15-0,2 \mathrm{~cm}$, lanceoladas, adaxialmente pubescentes no ápice, abaxialmente pubescentes, com tricomas concentrados na nervura, ciliadas. Corola lilás com linhas brancas no lobo central, 2-2,5 cm compr., internamente com 3 tufos de tricomas na porção mediana do tubo, externamente pilosa, tubo 1,1-1,5 cm compr., curvo, lábio superior 8-12 × 2-6 mm, bidentado no ápice; lábio inferior 1-1,4 $\times$ ca. $0,5 \mathrm{~cm}$. Filetes ca. $6 \mathrm{~mm}$ compr., pubescentes, anteras 3-4 mm compr., tecas oblíquas, múticas. Estilete ca. $1,8 \mathrm{~cm}$ compr., piloso; disco nectarífero anular. Cápsula
0,9-1,5 cm compr., glabra a pubérula, com porção fértil fusiforme, constrita entre as sementes; sementes 4, 2-3 mm diâm., suborbiculares, lisas, borda inteira.

Material selecionado: BRASIL. BAHIA: Boquira, 11-III-1998, fr., G. Hatschbach 67604 (HUEFS); Caturama, estrada entre Caieiras e Tamboril, $13^{\circ} 17^{\prime} 47^{\prime \prime S} 42^{\circ} 14 ' 50 " \mathrm{~W}, 22-\mathrm{IV}-2008$, fl., A.L.A. Côrtes et al. 100 (HUEFS); Lagoinha, $33 \mathrm{~km} \mathrm{NW}$ da cidade, na estrada para Minas do Mimoso, $10^{\circ} 16^{\prime} \mathrm{S} 41^{\circ} 23^{\prime} \mathrm{W}$, 650 m s.n.m., 7-III-1974, fl., R.M. Harley et al.16885 (RB); Oliveira dos Brejinhos, Canabrava, 16-III-1998, fl., G. Hatschbach et al. 67782 (CEPEC, MBM); Paramirim, $13^{\circ} 17^{\prime} 47^{\prime \prime S ~} 42^{\circ} 14^{\prime} 50^{\prime \prime W}, 546$ m s.n.m., 29-IV-2007, fl., A.A. Conceição et al. 1963 (HUEFS); Rio de Contas, estrada de terra a $2 \mathrm{~km}$ de Rio de Contas, $8 \mathrm{~km}$ até a fazenda Marion, rio Baêta, 13³7'51,3"S 41ㄴ'4'42,1"W, 960 m s.n.m., 26-III-2008, fl., bot., A.L.A. Côrtes et al. 74 (HUEFS); Tucano, povoado Bizamum, fazenda do Gordo, próximo à fonte, $10^{\circ} 53^{\prime} \mathrm{S}$ $38^{\circ} 58^{\prime} \mathrm{W}, 236$ m s.n.m., 20-IV-2005, fl., fr., D.B.O.S. Cardoso \& W.J. Lima 477 (HUEFS).

Justicia thunbergioides é caracterizada pela inflorescência em espigas secundifloras congestas ou solitárias subtendidas por uma bráctea grande e foliácea com as nervuras bem marcadas. A corola possui o ápice do lábio superior reflexo e, em algumas populações, as brácteas são arroxeadas. Algumas populações apresentam flores solitárias e outras em cimas axilares. Essa variação é comentada por Wasshausen \& Wood (2003), que, estudando as espécies da Bolívia, incluíram seis espécies na sinonímia desse nome. Entre os extremos dessa variação [J. lilloi (Lotti) C. Ezcurra, com flores solitárias na axila das folhas superiores, e $J$. thunbergioides, com espigas secundifloras axilares envolvidas por brácteas ovadas], há uma série de indivíduos intermediários, sem que haja outro caráter para separá-los. É encontrada na Bolívia, norte da Argentina e no Brasil (Mato Grosso, Goiás, Minas Gerais e Bahia), em locais secos de baixa altitude (Wasshausen \& Wood 2003). Na Bahia, ocorre entre 500 e $900 \mathrm{~m}$ de altitude, sendo frequente na caatinga, principalmente na borda de trilhas, sobre solo geralmente argiloso e pedregoso. Floresce e frutifica do verão ao inverno.

6.17. Justicia xipotensis (Roem. \& Schult.) A. Côrtes \& Rapini, Rodriguésia 61 (supl.): S90. 2010. Figuras 12 q-w, 13

Arbusto, 30-80 cm alt.; ramos subquadrangulares, pubescentes ou pilosos a glabrescentes, às vezes com 
tricomas glandulares. Pecíolo 0,5-1 cm compr.; lâmina 3,5-9 × 2,5-4,7 cm, elíptica a levemente ovada, pilosa, híspida ou pubescente em ambas as faces, ciliada, ápice agudo a atenuado, base longamente decorrente a decorrente. Inflorescências paniculiformes com espigas secundas; brácteas, 1-2 $\times$ ca. 0,6 mm, estreitamente lanceoladas, hispídula a escabra, com tricomas glandulares em ambas as faces; bractéolas 0,7-2 × ca. 0,6 mm, estreitamente lanceoladas, no mais, como às brácteas. Cálice 4-5 mm compr., lacínias 5, 3-4 × 0,6-1 mm, lanceoladas, escabras a hispídulas, com tricomas glandulares. Corola vermelha, 2,5-3,3 cm compr., internamente hirtela no tubo, glabra no restante, externamente hirtela, com tricomas glandulares, tubo $1,5-1,8 \mathrm{~cm}$ compr., ereto, lábio superior 0,9-1,5 × 0,4-0,5 cm, agudo a levemente bidentado no ápice, lábio inferior 1-1,8 $\times 0,1-0,2 \mathrm{~cm}$. Estames 2 (3, nas flores com lobos unidos), filetes 0,8-1,1 cm compr., tecas a superior 1,2-2 mm compr., com um prolongamento de ca. $1 \mathrm{~mm}$ compr. na base do filete ou do conectivo, pubescente dorsalmente, a inferior ca. $1 \mathrm{~mm}$ compr., tecas superpostas, apendiculada na base. Estilete ca. 2,5 cm compr., glabro; disco nectarífero anular. Cápsula 0,5-1,2 cm compr., pubérula, às vezes com tricomas glandulares, com porção fértil fusiforme, constrita entre as

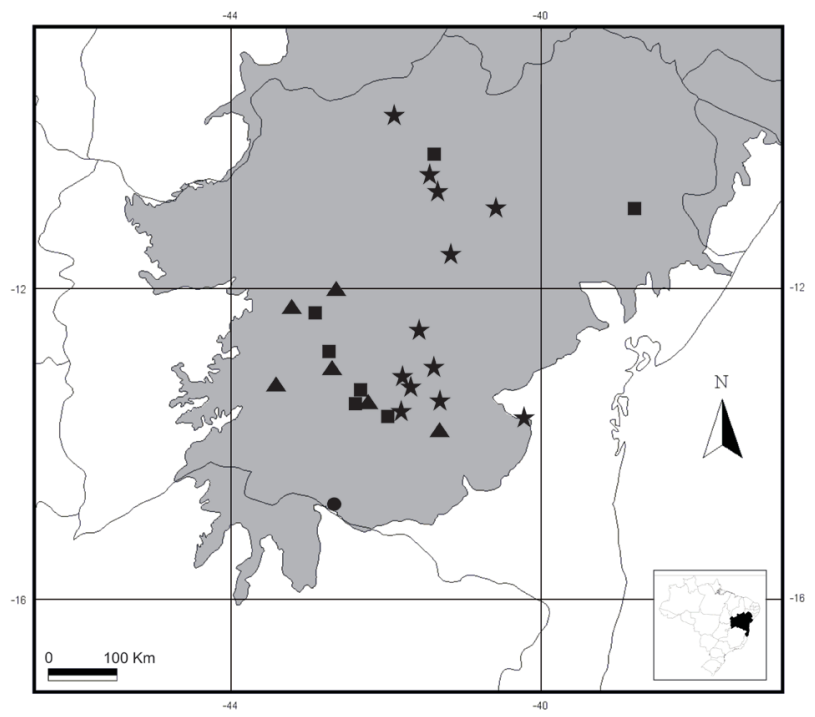

Figura 13. Distribuição de Justicia simonisia $(\bullet)$, J. thunbergioides $(\boldsymbol{\square})$, J. xipotensis $(\boldsymbol{\Delta})$ e Poikilacanthus bahiensis $(\star)$ no Semiárido do Estado da Bahia, Brasil (área cinza).

Figure 13. Distribution of Justicia simonisia $(\mathbf{\bullet})$, J. thunbergioides $(\boldsymbol{\square})$, J. xipotensis $(\boldsymbol{\Delta})$, and Poikilacanthus bahiensis $(\star)$ in the Semiarid of Bahia State, Brazil (gray area). sementes; sementes 4, 1-2 mm diâm., suborbiculares, tuberculadas, borda tuberculada.

Material examinado: BRASIL. BAHIA: Bom Jesus da Lapa, Juá, 500 m s.n.m., 5-IV-1992, fl., G. Hatschbach et al. 56618 (MBM); Brotas de Macaúbas, $12^{\circ} 00^{\prime} 34 " \mathrm{~S}$ 42 $43^{\prime} 50^{\prime \prime} \mathrm{W}, 712$ m s.n.m., 2-VI-2007, fl., fr., A.A. Conceição et al. 2130 (HUEFS); Ibotirama, BR-242, $10 \mathrm{~km} \mathrm{~L} \mathrm{da} \mathrm{cidade,} \mathrm{11-X-1981,} \mathrm{fl.,} \mathrm{fr.,}$ G. Hatschbach 44147 (CEPEC, MBM); Ituaçu, $13^{\circ} 48^{\prime} 50^{\prime \prime S} 41^{\circ} 16^{\prime} 41^{\prime \prime} \mathrm{W}, 23-\mathrm{VI}-1987$, fl., fr., L.P. Queiroz et al. 1690 (HUEFS); Macaúbas, estrada para Canatiba, subida da Serra Poção, 600 m s.n.m., 20-IV-1996, fl., G. Hatschbach et al. 65078 (MBM); Paramirim, $13^{\circ} 17^{\prime} 41^{\prime \prime S ~} 42^{\circ} 14^{\prime} 50 " \mathrm{~W}, 546$ m s.n.m., 29-IV-2007, fl., fr., A.A. Conceição et al. 1961 (HUEFS).

Material adicional examinado: BRASIL. MinAs GeraIs: ad. Xipotó fluvium, M.A.P. Wied-Neuwied (holótipo GZU n.v. - foto!).

Justicia xipotensis é o nome correto de Justicia leucophloea (Nees) Wassh., nome inválido (Côrtes \& Rapini 2010). A espécie é caracterizada pela inflorescência paniculiforme, ramos floríferos com tricomas glandulares, corola vermelha e estames com as tecas desiguais e em alturas diferentes. Algumas flores dos espécimes analisados apresentaram 3 estames, e esse estame adicional está associado com a união dos lábios da corola em um dos lados. Apresenta o hábito semelhante ao de J. glaziovii, mas é distinguida pelo tamanho da corola e por esta ser vermelha ( $v s$. lilás). Ocorre nos Estados de Minas Gerais e Bahia, sendo encontrada na Caatinga, em beira de estradas, lajedos rochosos e barrancos sombreados, e também no Cerrado. Floresce principalmente em abril, frutificando de junho a outubro.

7. Poikilacanthus Lindau, Bot. Jahrb. Syst. 18: 57. 1894.

Ervas ou arbustos perenes. Folhas pecioladas. Inflorescências em espigas ou capituliformes, axilar ou terminal, com 1 flor por nó; 1 bráctea e 2 bractéolas. Cálice com 5 lacínias, iguais. Corola bilabiada, não ressupinada; lábio superior côncavo ou ereto, bilobado, lábio inferior trilobado. Androceu com 2 estames exsertos, anteras bitecas, tecas oblíquas, apendiculadas na base, estaminódios ausentes. Cápsulas obovadas, estipitadas; sementes 4.

Poikilacanthus está representado por 14 espécies, a maioria delas ocorre na América do Sul, porém 
cinco são encontradas no México e na América Central (Daniel 1991). É distinguido dos demais gêneros da tribo, especialmente de Justicia, pelo pólen poliporado, com exina coberta de aréolas (Raj 1961, Lindau 1895, Daniel 1991). O gênero monotípico Megaskepasma Lindau, no entanto, apresenta pólen similar. O estudo filogenético têm corroborado a proximidade de Poikilacanthus com Justicia no clado das "Justicioides" do Novo Mundo (McDade et al. 2000a).

\subsection{Poikilacanthus bahiensis (Nees) Wassh., Kew}

Bull. 48(1): 17. 1993.

Figuras 13, 14 a-g, 18 e

Arbusto, 1-2 m alt.; ramos quadrangulares, pubescentes, hirsutos, tomentosos ou vilosos. Pecíolo 0,2-1,5 cm compr.; lâmina 3,5-14 × 1,5-6,7 cm, estreitamente elíptica a elíptica ou obovada, glabras ou abaxialmente escabras a vilosas e adaxialmente escabras a pilosas, ápice levemente arredondado ou agudo, base brevemente decorrente a cuneada. Inflorescência em espigas; brácteas verdes a vináceas, $0,7-2,3 \times 0,5-1,2 \mathrm{~cm}$, largamente espatuladas a espatuladas ou obovadas, pubescentes a escabras em ambas as faces, com tricomas glandulares ao longo da margem principalmente na porção distal; bractéola 0,5-5 $\mathrm{cm} \times 2-5 \mathrm{~mm}$, lanceolada a estreitamente espatulada, abaxialmente pubescente a escabra, adaxialmente pubescente, com tricomas glandulares na margem. Cálice ca. $1 \mathrm{~cm}$ compr., lacínias ca. $8 \times 2 \mathrm{~mm}$ compr., lanceoladas, puberulentas. Corola rósea a roxa, com estria alva no centro do lábio inferior, 2,8-3 cm compr., externamente hirtela, internamente com tufos de tricomas nas nervuras da base do tubo, tubo ca. $7 \mathrm{~cm}$ compr., curvo, lábio superior ca. $2 \mathrm{~cm}$ compr., bilobado no ápice, lábio inferior ca. $2 \mathrm{~cm}$ compr., lobos ca. $5 \mathrm{~mm}$ compr. Filetes ca. 1,8 cm compr., anteras ca. $3 \mathrm{~mm}$ compr., tecas oblíquas. Estilete ca. 2,6 cm compr., pubescente na porção basal; disco nectarífero cupular, tetralobado. Cápsula 1,5-2 cm compr., glabra, com a porção fértil obovoide; sementes 4, ca. 5 mm diâm., suborbiculares, lisas, borda inteira.

Material selecionado: BRASIL. BAHIA: Abaíra, estrada Ribeirão-Barra, perto de Emerlindo Barbosa, 1.120 m s.n.m., 12-III-1992, fl., bot., B. Stannard et al. 51890 (CEPEC, HUEFS, SPF); Delfino, Serra do Curral Feio, estrada velha Delfino-Mimoso

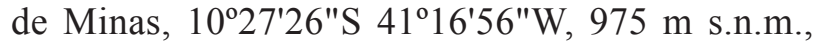

9-III-1997, fl., fr., bot., P. Gasson et al. 6178 (HUEFS, ALCB); Ibicoara, Cascavel, estrada de terra em direção a Água Fria, 13ำ17'10"S 4120'54"W, 1.072 m s.n.m., 16-II-2002, fl., fr., T.S. Nunes 880 (HUEFS); Lafaiete Coutinho, $100 \mathrm{~km}$ de Milagres na BR-116, 14-IV-1995, bot., E. Melo \& F. França 1184 (HUEFS); Mirangaba, $10^{\circ} 43^{\prime} \mathrm{S} 41^{\circ} 13^{\prime} \mathrm{W}, 27-\mathrm{IV}-1981$, bot., R.P. Orlandi 356 (HRB, HUEFS, RB); Morro do Chapéu, $12 \mathrm{~km}$ da cidade, no sentido Tamboril, Serra

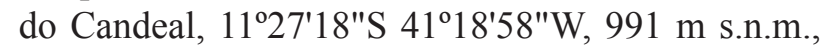
11-III-1996, fl., bot., A.M. Giulietti et al. 2274 (ALCB, HUEFS); Mucugê, Guiné, 1251'55"S 4130'25"W, 1.080 m s.n.m., 15-II-1997, fl., bot., L. Passos et al. 5721 (HUEFS, ALCB); Palmeiras, caminho para Conceição dos Gados, 12³1'59"S 4133'11"W, 21-III-2003, bot., E. Melo et al. 3536 (HUEFS);

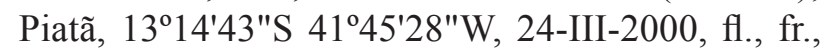
M.L. Guedes et al. 11497 (ALCB, CEPEC); Rio de Contas, estrada para Pico das Almas, 27-III-2008, fl., fr., A.L.A. Côrtes et al. 78 (HUEFS); Sento Sé, estrada entre Almas de Cima e Campo Largo, 10¹9'52"S 4123'52"W, 1.046 m s.n.m., 2-IV-2002, fl., bot., E.R. Souza et al. 133 (HUEFS); Umburanas, Serra do Curral Feio, entrando para W, $20 \mathrm{~km} \mathrm{~S} \mathrm{de}$ Delfino na estrada para Umburanas, $10^{\circ} 22^{\prime} \mathrm{S} 41^{\circ} 19^{\prime} \mathrm{W}$, 1.200 m s.n.m., 10-IV-1999, fl., L.P. Queiroz et al. 5226 (HUEFS).

Poikilacanthus bahiensis é reconhecida pelas espigas longas, axilares e terminais, com brácteas e bractéolas espatuladas, verdes a vináceas, com tricomas glandulares na margem. É endêmica do Estado da Bahia, encontrada na Caatinga, sendo abundante em bordas de mata e campos rupestres, em altitudes entre 800 e $1.900 \mathrm{~m}$. Ocorre predominantemente na Chapada Diamantina, florescendo e frutificando praticamente o ano todo.

8. Pseuderanthemum Radlk., Sitzungsber. Math.Phys. Cl. Königl. Bayer. Akad. Wiss. München 13: 282. 1883.

Ervas a arbustos. Folhas pecioladas ou sésseis. Inflorescências em espigas terminais e axilares, com 1 flor por nó; 1 bráctea e 2 bractéolas estreitas. Cálice com 5 lacínias estreitas e desiguais. Corola rosa, lilás ou azul, hipocrateriforme, lobos patentes, 5-partidos, imbricados. Androceu com 2 estames semiexsertos a inclusos, filetes curtos, anteras bitecas iguais, tecas paralelas, apendiculadas na base ou múticas, 2 estaminódios. Cápsulas obovadas-oblongas, estipitadas; sementes 4. 

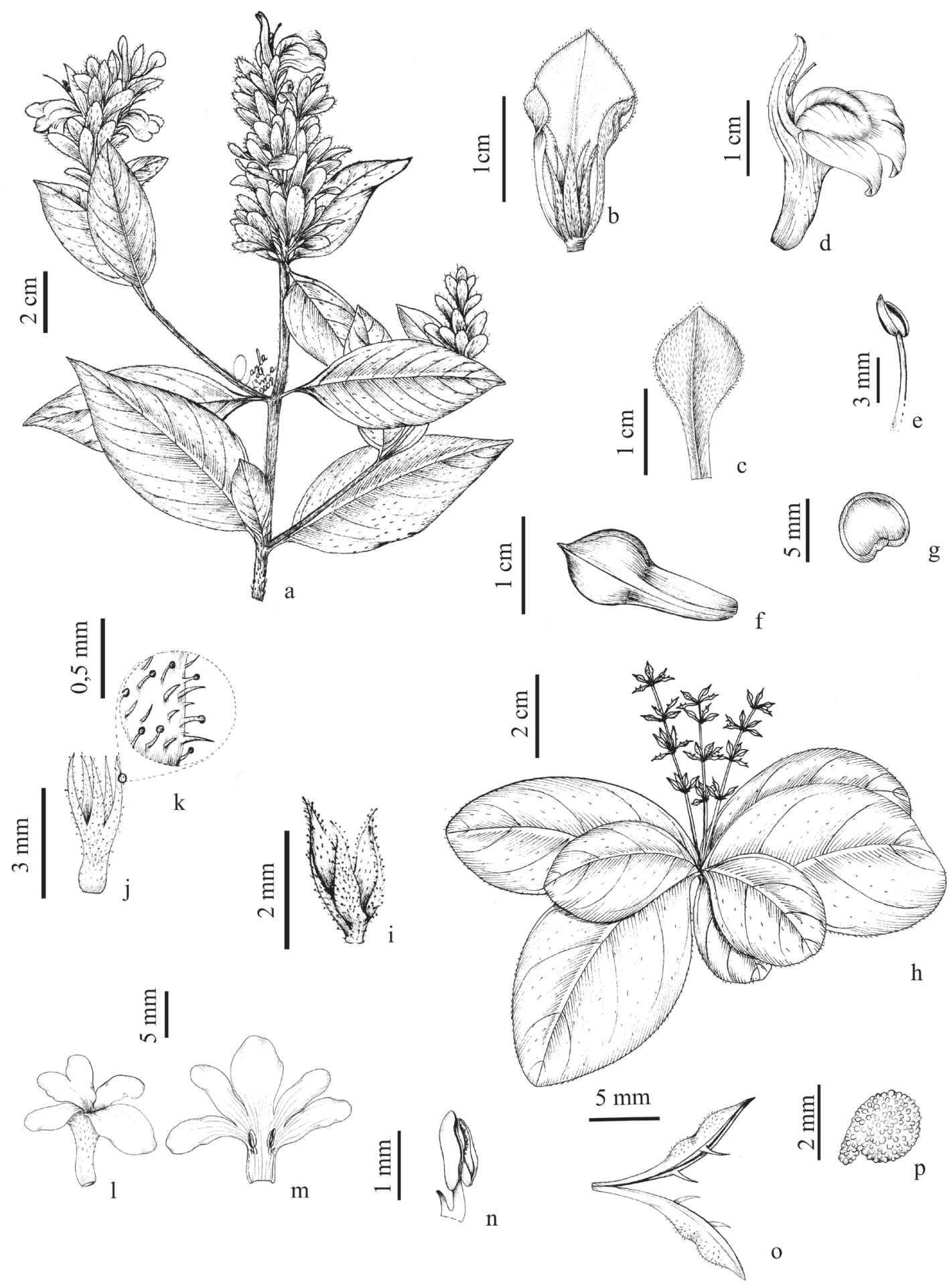

Figura 14. a-g. Poikilacanthus bahiensis. a. Ramo florido. b. Bráctea, bractéolas e cálice. c. Bráctea, face abaxial. d. Corola com estilete. e. Estame. f. Fruto. g. Semente. h-p. Pseuderanthemum modestum. h. Hábito. i. Bráctea e bractéolas. j. Cálice. k. Detalhe do indumento da face abaxial do cálice. 1. Corola. m. Corola, evidenciando os estames. n. Estame e estaminódio. o. Fruto. q. Semente. (a-g. Côrtes 78; h. Rapini 1428; i-p. Côrtes 36).

Figure 14. a-g. Poikilacanthus bahiensis. a. Flowering branch. b. Bract, bracteoles and calyx. c. Bract, abaxial surface. d. Corolla with style. e. Stamen. f. Fruit. g. Seed. h-p. Pseuderanthemum modestum. h. Habit. i. Bract and bracteoles. j. Calyx. k. Indumentum detail of abaxial calyx surface. 1. Corolla. m. Corolla, showing the stamens. n. Stamen and staminode. o. Fruit. q. Seed. (a-g. Côrtes 78; h. Rapini 1428; i-p. Côrtes 36). 
Pseuderanthemum é caracterizado pelas flores com corola hipocrateriforme e androceu composto de dois estames e dois estaminódios. Possui aproximadamente 60 espécies, frequentemente encontradas em regiões tropicais (McDade et al. 2000a). No trabalho filogenético (McDade et al. 2000a), aparece como grupo irmão dos demais da tribo, apresentando características plesiomórficas, como androceu com quatro elementos estaminais. Esse gênero é semelhante a Chamaeranthemum Nees, na forma da corola e nos elementos do androceu.

8.1. Pseuderanthemum modestum (Nees) Radlk., Sitzungsber. Math.-Phys. Cl. Königl. Bayer. Akad. Wiss. München 13: 286. 1883.

Nome popular: sipipira (in sched.).

Figuras 14h-p, 16, $18 \mathrm{f}$

Erva rizomatosa, 2,5-30 cm alt.; caule reduzido, com entrenós curtos e ramos quadrangulares. Pecíolo ca. 2 mm compr.; lâmina 1,5-17 × 1-8 cm, elíptica a obovada ou espatulada, glabra a esparsamente hirsuta em ambas as faces, com tricomas concentrados nas nervuras, ciliada, ápice agudo a arredondado e apiculado, base cuneada a longamente decorrente. Inflorescência em espiga terminal, com 1-4 flores; bráctea 1,5-3 × 0,5-0,68 mm, triangular, adaxialmente glabra a hirsuta, abaxialmente hirsuta, com tricomas glandulares; bractéolas 0,9-1 × 0,2-0,36 mm, triangulares, hirsutas, mais esparsamente na face abaxial, ciliadas. Cálice 2,5-3,5 mm compr. lacínias 2-2,5 $\times 0,3-0,48 \mathrm{~mm}$, lanceoladas, hirtelas, com tricomas glandulares. Corola lilás-esbranquiçada, 1-1,5 cm compr., hipocrateriforme, internamente glabra, externamente hirtela a quase glabra, tubo 5-6 mm compr., ereto, lobos 0,7-4,6 × 0,3-2,8 mm, oblongos. Estames inclusos, filetes $0,8-1,5 \mathrm{~mm}$ compr., anteras 1-1,2 mm compr., múticas; estaminódios ca. 0,7 mm compr. Estilete 4-4,1 mm compr., pubescente na base; disco nectarífero cupular. Cápsula 1-1,3 cm compr., hirtela, com tricomas glandulares, com porção fértil fusiforme, constrita entre as sementes; sementes 4, ca. 2 mm diâm., orbiculares, tuberculadas a verrucosas, borda tuberculada.

Material selecionado: BRASIL. BAHIA: Anguera, Morro da Fazenda Retiro, $12^{\circ} 10^{\prime} 01^{\prime \prime S} 39^{\circ} 11^{\prime} 16^{\prime \prime} \mathrm{W}$, 380 m s.n.m., 21-XI-2006, fr., D.B.O.S. Cardoso \& F. França 1430 (HUEFS); Antônio Cardoso, 20 km de Feira de Santana na Br-116, fazenda Sossego, 14-IV-1995, fl., bot., E. Melo \& F. França 1147 (HUEFS); Feira de Santana, Ipuaçu, estrada do Feijão, fazenda Chapada do Senhor Morais, $12^{\circ} 13^{\prime} \mathrm{S} 39^{\circ} 4^{\prime} \mathrm{W}$, 5-IX-2007, fr., A.L.A. Côrtes et al. 36 (HUEFS); Iaçu, Morro da Garrafa, $12^{\circ} 45^{\prime} 18^{\prime \prime S} 39^{\circ} 51^{\prime} \mathrm{W}, 275$ m s.n.m., 23-II-1997, fr., E. Melo et al. 2103 (HUEFS); Itatim, Morro das Tocas, $12^{\circ} 45^{\prime} 12^{\prime \prime S} 39^{\circ} 46^{\prime} \mathrm{W}, 300$ m s.n.m., 26-I-1997, fr., E. Melo et al. 1972 (HUEFS).

Pseuderanthemum modestum é reconhecida pela pequena estatura; as folhas aparentam disposição em roseta e ficam em contato com o solo, as espigas são eretas, com flores fasciculadas. É encontrada no interior de mata estacional de encosta, normalmente na base de inselbergs. Até o momento, só foi encontrada nos Estados da Bahia e Minas Gerais, sendo endêmica do Semiárido. Floresce e frutifica o ano todo.

9. Schaueria Nees, Ind. Sem. Hort. Vratisl.: 3. 1838.

Ervas a arbustos. Folhas pecioladas. Inflorescências tirsos, racemos ou espigas terminais e axilares, com 1 a várias flores por nó; 1 bráctea e 2 bractéolas, lineares ou raramente lanceoladas, ovadas. Cálice com 5 lacínias, iguais a subiguais. Corola bilabiada, não ressupinada, lábio superior inteiro a bilobado, ereto ou inflexo; lábio inferior trilobado. Androceu com 2 estames exsertos, anteras bitecas, tecas paralelas, iguais, múticas, estaminódios ausentes. Cápsulas clavadas, estipitadas; sementes 4.

Schaueria é um gênero neotropical, ocorrendo no México, Guatemala e América do Sul e incluindo de 10 a 15 espécies (Daniel 1998). É caracterizado pelas brácteas e bractéolas estreitas, corola branca a amarela geralmente pequena. Está inserido na "linhagem Tetramerium", formando um clado com Thyrsacanthus, Pachystachys Nees e Streblacanthus Kuntze (McDade et al. 2000a, Daniel et al. 2008).

9.1. Schaueria humuliflora Nees \& Mart. in Martius, Fl. Bras. 9: 102. 1847.

Figuras $15 \mathrm{a}-\mathrm{g}, 16,18 \mathrm{~g}$

Arbusto, 30-40 cm alt.; ramos subcilíndricos a cilíndricos, pilosos a hirsutos. Pecíolo 0,7-1,5 cm compr.; lâmina 4,5-9 × 2-5,5 cm, elíptica a ovada, com tricomas esparsos nas nervuras em ambas as faces, ápice agudo a atenuado ou apiculado, base curtamente decorrente. Inflorescência em espigas axilares e terminais, 1-3 flores; brácteas 1-1,2 $\times$ ca. $1 \mathrm{~cm}$, largamente ovadas, pubérulas a esparsamente hirtelas em ambas as faces, com tricomas glandulares, ciliadas; bractéolas ca. $4 \times 0,3 \mathrm{~mm}$, estreitamente triangulares a lineares, hirtelas, eventualmente ciliadas. Cálice ca. $4 \mathrm{~mm}$ compr., lacínias 5 , ca. $3 \times 0,8 \mathrm{~mm}$, 

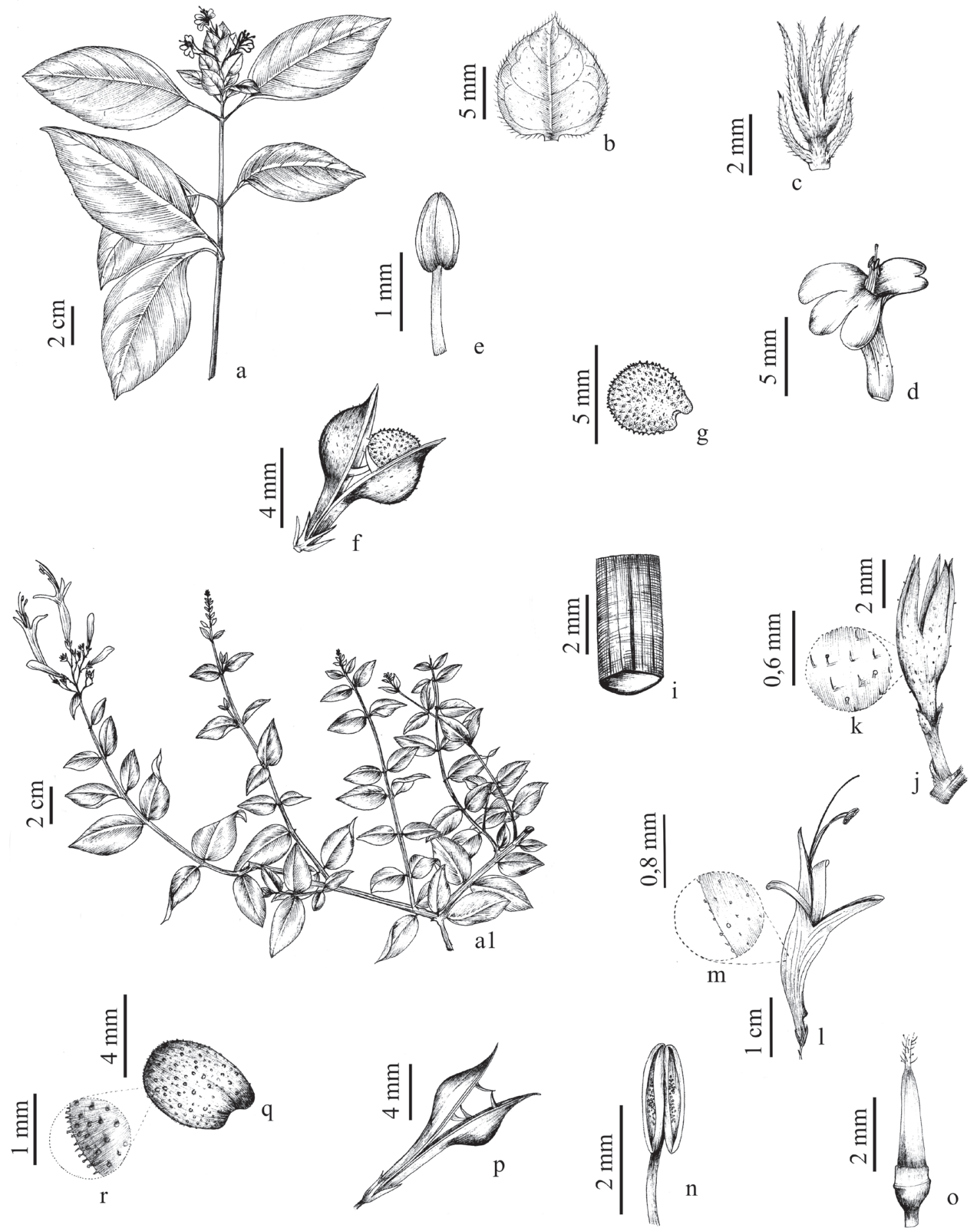

Figura 15. a-g. Schaueria humuliflora. a. Ramo florido. b. Bráctea, face abaxial. c. Bractéolas e cálice. d. Corola com estames e estilete. e. Estame. f. Fruto com semente. g. Semente. h-r. Thyrsacanthus ramosissimus. h. Ramo florido. i. Detalhe do caule. j. Bráctea, bractéolas e cálice. k. Detalhe do indumento da face abaxial do cálice. 1. Flor. m. Detalhe do indumento externo da corola. n. Estame. o. Disco nectarífero, ovário e base do estilete. p. Fruto. q. Semente. r. Detalhe da testa da semente. (a-g. Côrtes 31; i-o. Côrtes 85; p-r. Melo 3641).

Figure 15. a-g. Schaueria humuliflora. a. Flowering branch. b. Bract, abaxial surface. c. Bracteoles and calyx. d. Corolla with stamens and style. e. Stamen. f. Fruit with seed. g. Seed. h-r. Thyrsacanthus ramosissimus. h. Flowering branch. i. Stem detail. j. Bract, bracteoles and calyx. k. Indumentum detail of abaxial calyx surface. 1. Flower. m. Indumentum detail of outer corolla. n. Stamen. o. Nectariferous disk, ovary, base of the style. p. Fruit. q. Seed. r. Seed coat detail. (a-g. Côrtes 31; i-o. Côrtes 85; p-r. Melo 3641). 
estreitamente triangulares a lineares, hirtelas, eventualmente ciliadas. Corola alva, 1-1,2 cm compr., internamente pubérula até a fauce, glabra nos lobos, externamente hispídula a hirtela, tubo 6-7 mm compr., ereto, lábio superior ca. $4 \times 1 \mathrm{~mm}$, bilobado no ápice, lábior inferior 4-5 × 1-2 mm. Filetes ca. $2 \mathrm{~mm}$ compr., anteras ca. $1 \mathrm{~mm}$ compr., tecas paralelas. Estilete ca. $8 \mathrm{~mm}$ compr., piloso na base; disco nectarífero anular. Cápsula ca. $9 \mathrm{~mm}$ compr., hirtela, com porção fértil obovoide; sementes ca. $4 \mathrm{~mm}$ diâm., suborbiculares, tuberculada, borda gloquidiada.

Material examinado: BRASIL. BAHIA: Rio Belmont, via felisbertia, 1834, fr. M.A.P. Wied-Neuwied s.n. (holótipo BR n.v. - foto!); Anguera, fazenda Retiro, $12^{\circ} 09^{\prime} 55^{\prime \prime S} 39^{\circ} 10^{\prime} 51^{\prime \prime} \mathrm{W}, 303$ m s.n.m., 12-II-2006, fl., bot., M.H.S. Ferreira \& F. França 20 (HUEFS); Feira de Santana, Ipuaçu, fazenda Chapada do Sr. José Morais, $12^{\circ} 13^{\prime} \mathrm{S} 39^{\circ} 04^{\prime} \mathrm{W}, 5$-IX-2007, fl., fr., bot., A.L.A. Côrtes et al. 31 (HUEFS).

Schaueria humuliflora é caracterizada pelas espigas com brácteas verde-claras, ciliadas, largamente ovadas e imbricadas e pelas flores alvas, relativamente pequenas, com lábio superior estreito. Diferencia das outras espécies do gênero por ser a única que apresenta brácteas largamente ovadas ( $v s$. lineares

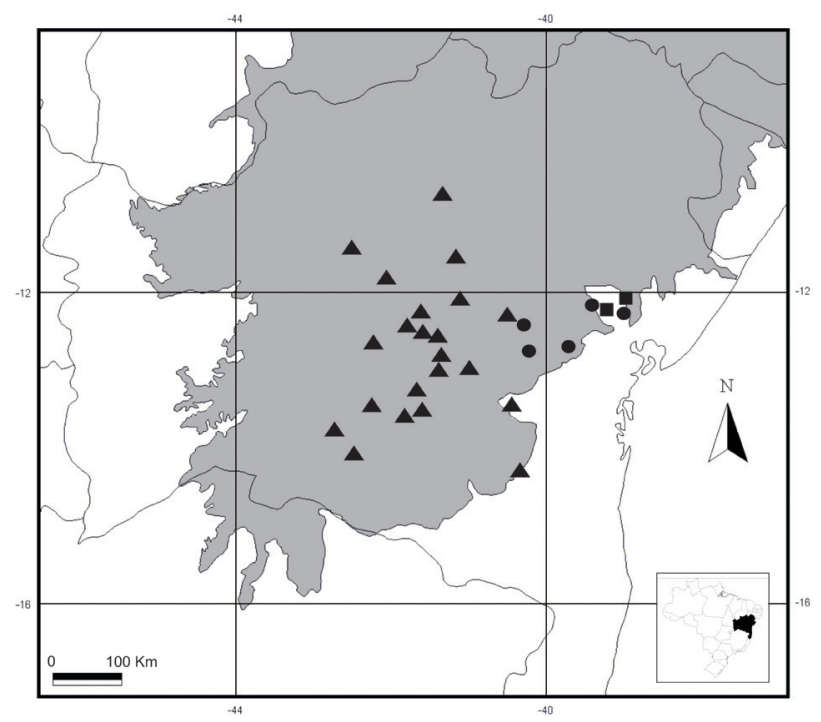

Figura 16. Distribuição de Pseuderanthemum modestum (0), Schaueria humuliflora $(\mathbf{\square})$, Thyrsacanthus ramosissimus $(\mathbf{\Delta})$ no Semiárido do Estado da Bahia, Brasil (área cinza).

Figure 16. Distribution of Pseuderanthemum modestum (-), Schaueria humuliflora ( $\mathbf{\square})$, and Thyrsacanthus ramosissimus $(\boldsymbol{\Delta})$ in the Semiarid of Bahia State, Brazil (gray area). a lanceoladas). É endêmica do Semiárido do Estado da Bahia, ocorrendo em caatingas. Floresce principalmente no verão e frutifica comumente na primavera.

10. Thyrsacanthus Moric., Pl. Nouv. Amer. 9: 165. 1847.

Arbustos ramificados; ramos cilíndricos. Folhas pecioladas ou sésseis. Inflorescências em racemos, espigas, tirsos, secundas ou opostas, axilares ou terminais; 1 bráctea e 2 bractéolas geralmente inconspícuas. Cálice geralmente com 5 lacínias, iguais. Corola geralmente vermelha, bilabiada, não ressupinada; lábio superior geralmente inteiro ou ligeiramente bilobado, lábio inferior trilobado, com lobos recurvados. Androceu com 2 estames exsertos, anteras bitecas, tecas paralelas, múticas, estaminódios ausentes. Cápsulas ovadas, estipitadas; sementes 2-4.

Thyrsacanthus inclui cerca de cinco espécies arbustivas, distribuídas principalmente em regiões secas da América do Sul, com folhas lineares a ovadas, corola bilabiada e vermelha (Côrtes et al. 2010). As espécies que compõem esse gênero foram segregadas de Anisacanthus com base em análise filogenética molecular. Estudos com dados moleculares mostraram que as espécies da América do Norte e da América do Sul surgiram independentemente (Daniel et al. 2008), o que é corroborado pela morfologia floral, já que nas espécies da América do Sul as flores são nototríbicas (com os estames próximos ao lábio superior) e as das Américas do Norte e Central são esternotríbicas (com estames próximos ao lábio inferior).

10.1. Thyrsacanthus ramosissimus Moric., P1. Nouv. Amer. 9: 165. 1847.

Figuras 15h-r, 16, 18 h-i

Arbusto 1,5-3,5 m alt.; ramos subcilíndricos, estrias finas, inconspícuas, pubescentes a escabrosos. Folhas subsésseis, lâmina 1-7 × 0,5-3,7 cm, ovada a elíptica ou lanceolada, glabra a pubescente em ambas as faces, ciliada, ápice obtuso a agudo, base obtusa a cuneada. Inflorescências em tirsos de monocásios, axilares ou terminais, monocásios pecundulados 1-3 mm compr.; bráctea 3-10 × 1-4 mm, lanceolada a linear, adaxialmente glabra, abaxialmente estrigosa, esparsamente ciliada; bractéolas ca. $2 \times 0,3 \mathrm{~mm}$, lanceoladas, indumento similar ao das brácteas. Pedicelo 1-2 mm compr. Cálice ca. 5,3 mm compr., lacínias 5, iguais entre si, 1-3,4 × 0,7-1 mm, 

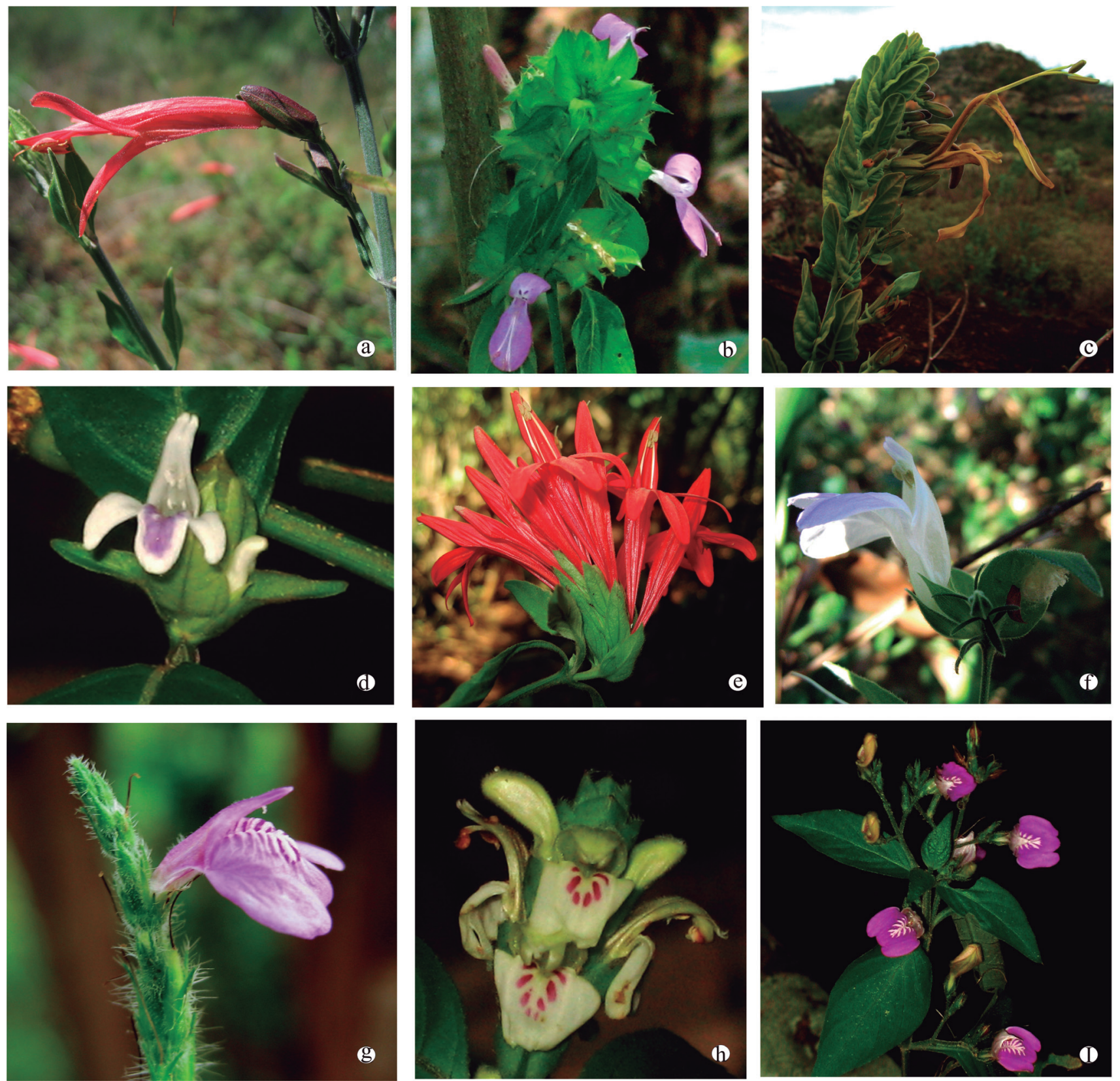

Figura 17. a. Anisacanthus trilobus. b. Dicliptera mucronifolia. c. Harpochilus neesianus. d. Herpetacanthus magnobracteolatus. e. Justicia aequilabris. f. J. asclepiadea. g. J. chamaedryoides. h. J. cuneifolia. i. J. glaziovii.

Figure 17. a. Anisacanthus trilobus. b. Dicliptera mucronifolia. c. Harpochilus neesianus. d. Herpetacanthus magnobracteolatus. e. Justicia aequilabris. f. J. asclepiadea. g. J. chamaedryoides. h. J. cuneifolia. i. J. glaziovii. 

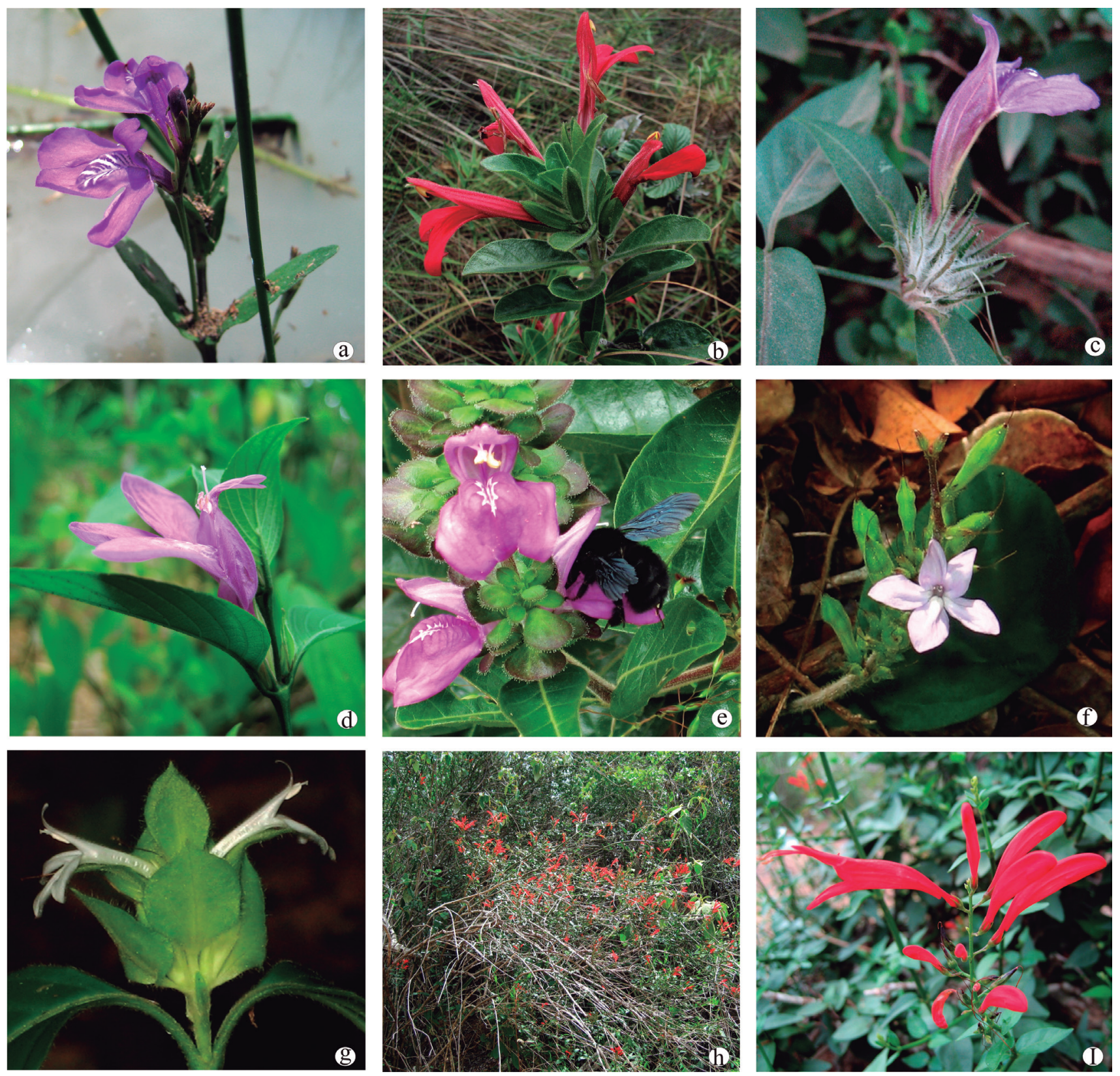

Figura 18. a. Justicia laevilinguis. b. J. lepida. c. J. simonisia. d. J. thunbergioides. e. Poikilacanthus bahiensis. f. Pseuderanthemum modestum. g. Schaueria humuliflora. h-i. Thyrsacanthus ramosissimus. h. Habito. i. Inflorescência.

Figure 18. a. Justicia laevilinguis. b. J. lepida. c. J. simonisia. d. J. thunbergioides. e. Poikilacanthus bahiensis. f. Pseuderanthemum modestum. g. Schaueria humuliflora. h-i. Thyrsacanthus ramosissimus. h. Habit. i. Inflorescence. 
lanceoladas, pubescentes a escabrosas, com tricomas glandulares. Corola vermelha, 2,5-3,5 cm compr., bilabiada, pubérula em ambas as faces, às vezes com tricomas glandulares externamente, tubo $2-2,5 \mathrm{~cm}$ compr., ventralmente giboso no terço basal, lábio superior ca. $1 \times 0,4 \mathrm{~cm}$, bilobado no ápice, lábio inferior 7-8 $\times 2-3 \mathrm{~mm}$. Filetes 2,7-3 cm compr., anteras 1-3 mm compr., tecas paralelas. Estilete 3-3,4 cm compr., pubescente na metade basal, com tricomas glandulares; disco nectarífero cupular. Cápsula 1-1,6 cm compr., glabra a pubérula ou pubescente, com porção fértil obovoide; sementes ca. $5 \mathrm{~mm}$ diâm., orbiculares, tuberculadas, borda gloquidiada.

Material selecionado: BRASIL. BAHIA: Serra Açurura, J.S. Blanchet 2893 (holótipo G n.v. - K foto!); Abaíra, estrada a $2 \mathrm{~km}$ de Catolés, Lambedor, $13^{\circ} 18^{\prime} \mathrm{S} 41^{\circ} 49^{\prime} \mathrm{W}$, 1.080 m s.n.m., 14-III-1993, fl., bot., B. Stannard et al. 51927 (CEPEC, HUEFS, SPF); Andaraí, $40 \mathrm{~km}$ na estrada para BR-242, 13-IV-1990, fl., bot., A.M. Carvalho \& W.W. Thomas 3024 (CEPEC, HUEFS); Barra do Mendes, Serra do Retiro, 20-II-2001, bot., M.V. Moraes 195 (HUEFS); Caetité, 3 km na estrada para Brejinho das Ametistas, $14^{\circ} 05^{\prime} \mathrm{S} 42^{\circ} 29^{\prime} \mathrm{W}$ 1.000 m s.n.m., 10-IV-1980, fl., bot., R.M. Harley et al. 21175 (CEPEC); Gentio de Ouro, estrada para Brotas de Macaúbas, $11^{\circ} 27^{\prime} 54$ "S 42³1'38"W, 1.139 m s.n.m., 17-V-2002, fl., bot., E.R. Souza 292 (HUEFS); Ibitiara, BR-242 para Seabra, $12^{\circ} 25^{\prime} 42,3^{\prime \prime S} 42^{\circ} 06^{\prime} 57,3^{\prime \prime} \mathrm{W}$, 1.104 m s.n.m., 24-IV-2008, fl., fr., A.L.A. Côrtes et al. 108 (HUEFS); Igaporã, BR-430, 5-6 km E da cidade, 15-III-1995, fl., fr., G. Hatschbach et al. 61951 (CEPEC, MBM); Itaeté, Gruta Poço Encantado, $12^{\circ} 56^{\prime} 40^{\prime \prime S} 41^{\circ} 06^{\prime} 20^{\prime \prime W}, 390$ m s.n.m., 13-VII-2003, fl., bot., F. França et al. 4780 (HUEFS); Iraquara, Água de Rega, $3 \mathrm{~km}$ na estrada para Seabra, 31-III-1993, fl., C. Kameyama \& G.L. Esteves 57 (SPF); Jussiape, Serra da Jiboia, 8-IV-1992, fl., G. Hatschbach et al. 56834 (CEPEC, MBM); Lençóis, margem da estrada

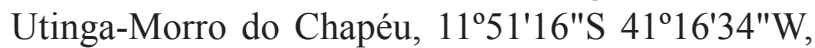
1.000 m s.n.m., 10-III-1996, fl., bot., E. Woodgyer et al. 2230 (ALCB, HUEFS); Maracás, estrada para Cruzeiro, $13^{\circ} 23^{\prime} \mathrm{S} 40^{\circ} 18^{\prime} \mathrm{W}, 25-\mathrm{III}-2008$., fl., fr., bot., A.L.A. Côrtes et al. 67 (HUEFS); Morro do Chapéu, Serra do Tombador, 15-VII-1979, fl., fr., G. Hatschbach \& O. Guimarães 42372 (CEPEC, MBM, $\mathrm{SPF})$; Mucugê, estrada de Guiné para Palmeiras, $12^{\circ} 45^{\prime} \mathrm{S} 41^{\circ} 30^{\prime} \mathrm{W}, 1.000$ m s.n.m., 20-VI-2005, fl., bot., D.B.O.S. Cardoso \& A.A. Conceição 589 (HUEFS); Palmeiras, caminho para Serra Preta, $12^{\circ} 31^{\prime} 55^{\prime S} \mathrm{~S}$
4135'14"W, 28-III-2003, fr., E. Melo et al. 3641 (HUEFS); Paramirim, $19 \mathrm{~km}$ na estrada para Caetité, 133'ㄴ'"S 4216'53"W, 888 m s.n.m., 19-IV-2001, fl., bot., T.R.S. Silva et al. 99 (HUEFS); Rio de Contas,

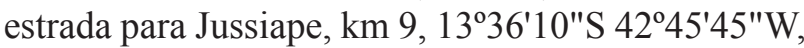
816 m s.n.m., 23-V-2004, fl., G. Pereira-Silva et al. 9115 (HUEFS, SPF); ibid. estrada para Jussiape, $13^{\circ} 26$ '58,2"S 4132'52,7"W, 28-III-2008, fl., A.L.A. Côrtes et al. 85 (HUEFS); Rui Barbosa, trilha para o Pátio das Orquídeas, $12^{\circ} 18^{\prime} 07^{\prime \prime S} 40^{\circ} 29^{\prime} 15^{\prime \prime} \mathrm{W}$, 518 m s.n.m., 28-VII-2004, fl., bot., L.P. Queiroz 9383 (HUEFS); Seabra, estrada para Boninal, 13-II-1987, fl., J.R. Pirani et al. 2013 (SPF); Umburanas, Serra da Empreitada, $10^{\circ} 22^{\prime} \mathrm{S} 41^{\circ} 19^{\prime} \mathrm{W}, 1.000$ m s.n.m., 10-IV-1999, fl., bot., L.P. Queiroz et al 5296 (HUEFS); Utinga, estrada para Wagner, 22-XII-1984, fl., R.M. Harley et al. 36451 (SPF).

Thyrsacanthus ramosissimus é um arbusto profusamente ramificado, formando tirsos terminais. A corola é vermelha, levemente gibosa na porção basal do tubo. Vinha sendo identificada como Anisacanthus brasiliensis Lindau, espécie que se mostrou sinônimo de Thyrsacanthus ramosissimus. Ocorre no Semiárido dos Estados de Minas Gerais a Pernambuco, sendo comum no Semiárido da Bahia, onde é encontrada geralmente em beiras de mata, especialmente em matas de cipó, Caatinga arbustivo-arbórea e Cerrado, normalmente em solos argilosos ou arenosos. Também foi encontrada em zonas de restinga no Estado do Rio Grande do Norte. Floresce de março a julho e frutifica de fevereiro a maio.

\section{Agradecimentos}

Os autores agradecem aos curadores dos seguintes herbários, pelo empréstimo de material e/ ou assistência durante a visita: ALCB, CEPEC, HRB, HUEFS, MBM, RB, SP, SPF e UB; à especialista em Acanthaceae Dra. Cíntia Kameyama, pelo apoio e discussões; ao Pedro Moraes, por disponibilizar fotografias de alguns tipos; à Carla de Lima, pelas ilustrações; a todos que nos apoiaram e acompanharam durante as coletas de campo, incluindo familiares; à Pós-graduação em Botânica (PPGBot) da UEFS e aos projetos Flora da Bahia (CNPq), Instituto do Milênio do Semiárido (IMSEAR; CNPq) e Programa de Pesquisa em Biodiversidade (PPBio) do Semiárido (MCT). A. Rapini é contemplado com bolsa PQ do CNPq. 


\section{Literatura citada}

Amorim, A.M., Fiaschi, P., Jardim, J.G., Thomas, W.W., Clifton, B.C. \& Carvalho, A.M.V. 2005. The vascular plants of a forest fragment in southern Bahia, Brazil. Sida 21: 1727-1752.

Barbosa, M.R., Sothers, C., Mayo, S., Gamarra-Rojas, C.F.L. \& Mesquita, A.C. (orgs.). 2006. Checklist das plantas do Nordeste Brasileiro: Angiospermas e Gimnospermas. Ministério de Ciência e Tecnologia, Brasília.

Bentham, G. 1876. Acanthaceae. In: G. Bentham \& W.J. Hooker (eds.). Genera plantarum. Reeve \& Co, London, v.2, pp. 1060-1122.

Braz, D.M., Carvalho-Okano, R.M. \& Kameyama, C. 2002. Acanthaceae da Reserva Florestal Mata do Paraíso. Viçosa, Minas Gerais. Revista Brasileira de Botânica 25: 495-504.

Bremekamp, C.E.B. 1965. Delimitation and subdivision of the Acanthaceae. Bulletin of the Botanical Survey of India 7: 21-30.

Cabral, A.G.S., Tenório-Souza, F.H., Moura, M.D., Mota, S.G.R., Lins, A.C.S., Dias, C.S., Barbosa-Filho J.M.B, Giulietti, A.M., Silva, T.M.S. \& Santos, C.F. 2012. Phaephytins from Thyrsacanthus ramosissimus Moric. with inhibitory activity in human DNA topoisomerase II $\alpha$. Quimica Nova 35: 2222-2225.

Cardoso, D.B.O.S. \& Queiroz, L.P. 2008. Floristic composition of seasonally dry tropical forest fragments in Central Bahia, Northeastern Brazil. Journal of the Botanical Research Institute of Texas 2: 551-573.

Côrtes, A.L.A. \& Rapini, A. 2010. Notas taxonômicas em Justicieae (Acanthaceae) no estado da Bahia, Brasil. Rodriguésia 61(supl.): S89-S91.

Côrtes, A.L.A., Borges, R.L.B. \& Rapini, A. 2010. Reinstatement of Thyrsacanthus Moric. (Acanthaceae) and taxonomic novelties in the genus. Taxon 59: 965-972.

Daniel, T.F. 1986. Systematics of Tetramerium (Acanthaceae). Systematic Botany Monographs 12: 1-134.

Daniel, T.F. 1991. A synopsis of Poikilacanthus (Acanthaceae) in Mexico. Bulletin of the Torrey Botanical Club 118: 451-458.

Daniel, T.F. 1998. Pollen Morphology of Mexican Acanthaceae: diversity and systematic significance. Proceedings of the California Academy of Sciences 50: 217-256.

Daniel, T.F., McDade L.A., Manketelow, M. \& Kiel, C.A. 2008. The "Tetramerium lineage" (Acanthaceae: Acanthoideae: Justicieae): delimitation and intra-lineage relationships based on $\mathrm{cp}$ and nrITS sequence data. Systematic Botany 33: 416-436.
Ezcurra, C. 2002. El género Justicia (Acanthaceae) en Sudamérica Austral. Annals of the Missouri Botanical Garden 89: 225-280.

Giulietti, A.M., Harley, R.M. \& Queiroz, L.P. 2002. Espécies endêmicas da Caatinga. In: E.V.S. B. Sampaio, A.M. Giulietti, J. Virgínio \& C.F.L. Gamarra-Rojas (eds.). Vegetação e Flora da Caatinga. Associação Plantas do Nordeste, Recife, pp. 103-118.

Graham, V.A.W. 1988. Delimitation and infra-generic classification of Justicia (Acanthaceae). Kew Bulletin 43: 551-624.

Grant, W.F. 1955. A cytogenetic study in the Acanthaceae. Brittonia 8: 121-150.

Harley, R.M. \& Simmons, N.A. 1986. Florula of Mucugê, Chapada Diamantina, Bahia, Brazil. Royal Botanic Gardens, Kew.

Harvey, Y.B. \& Wasshausen, D.C. 1995. Acanthaceae. In: B. Stannard (ed.). Flora of the Pico Almas, Chapada Diamantina, Bahia-Brasil. Royal Botanic Gardens, Kew, pp. 112-113.

Hickey, L.J. 1973. Classification of architecture of dicotyledons leaves. American Journal of Botany 60: 17-33.

Indriunas, A. 2011. Revisão taxonômica de Herpetacanthus Nees (Acanthaceae). Dissertação de Mestrado, Instituto de Botânica, São Paulo.

Indriunas, A. \& Kameyama, C. 2012. New species of Herpetacanthus (Acanthaceae) from the Atlantic Forest and neighboring areas (Brazil). Systematic Botany 37: 1006-1022.

Kameyama, C. 1995. Flora da Serra do Cipó, Minas Gerais: Acanthaceae. Boletim de Botânica da Universidade de São Paulo 14: 181-206.

Kameyama, C. 2003a. Flora de Grão-Mogol, Minas Gerais: Acanthaceae. Boletim de Botânica da Universidade de São Paulo 21: 51-53.

Kameyama, C. 2003b. Acanthaceae. In: D.C. Zappi, E. Lucas, B.L. Stannard, E. Nic Lughanda, J.R. Pirani, L.P. Queiroz, S. Atkins, N.D.J. Hind, A.M. Giulietti, R.M. Harley \& A.M. Carvalho (eds.). Lista de plantas vasculares de Catolés, Chapada Diamantina, Bahia, Brasil. Boletim de Botânica da Universidade de São Paulo 21: 345-398.

Kameyama, C. 2006. Flora da Reserva Ducke, Amazonas, Brasil: Acanthaceae. Rodriguésia 57: 149-154.

Lindau, G. 1895. Acanthaceae. In: A.H.G. Engler \& K.A.E. Prantl (eds.). Die natürlichen Pflanzenfamilien. Engelmann, Leipizig, v.4(3b), pp. 274-354.

Lobão, J.S.B., Rocha, F., Freitas, W.J.S. \& Barbosa, N. 2004. Semi-árido da Bahia, limites físico ou sócio-político? Uma abordagem geotecnológica para a delimitação oficial. In: Anais II Simpósio regional de geoprocessamento e sensoriamento remoto, Aracaju, pp. 1-4. 
McDade, L.A. \& Moody, M.L. 1999. Phylogenetic relationships among Acanthaceae: evidence from noncoding trnL-trnF chloroplast DNA sequences. American Journal of Botany 86: 70-80.

McDade, L.A., Daniel, T.F., Masta, S.E. \& Riley, K.M. 2000a. Phylogenetic relationships within the tribe Justicieae (Acanthaceae): evidence from molecular sequences, morphology and cytology. Annals of the Missouri Botanical Garden 87: 435-458.

McDade, L.A., Masta, S.E., Moody, M.L. \& Waters, E. 2000b. Phylogenetic relationships among Acanthaceae: evidence from two genomes. Systematic Botany 25: 106-121.

Nees, C.G. 1847 a. Acanthaceae. In: C.F.P. Martius (ed.). Flora Brasiliensis. F. Fleischer, Lipsiae, v.9, pp. 1-164.

Nees, C.G. 1847 b. Acanthaceae. In: A.P. Candolle (ed.). Prodromus systematis naturalis regni vegetabilis. Treuttel \& Würtz, Paris, v.11, pp. 46-519.

Profice, S.R. 1997. Acanthaceae. In: M.C.M. Marques, A.S.F. Vaz \& R. Marquete (eds.). Flórula da APA Cairuçu, Parati, RJ: espécies vasculares. Série Estudos e Contribuições. Jardim Botânico do Rio de Janeiro, Rio de Janeiro, v.14, pp. 9-23.

Profice, S.R. 1998. Acanthaceae. In: M.P.M. Lima \& R. Guedes-Bruni (ed.). Reserva Ecológica de Macaé de Cima, Nova Friburgo-RJ. Aspectos florísticos das espécies vasculares. Jardim Botânico do Rio de Janeiro, Rio de Janeiro, v.2, pp. 23-35.

Profice, S.R., Kameyama, C., Côrtes, A.L.A., Braz, D.M., Indriunas, A., Vilar, T., Pessoa, C., Ezcurra, C. \& Wasshausen, D. 2010. Acanthaceae. In: R.C. Forzza et al. (orgs.). Lista de Espécies da Flora do Brasil. Jardim Botânico do Rio de Janeiro, Rio de Janeiro. http://floradobrasil.jbrj.gov.br/2010/FB000033 (acesso em 19.10.2010).

Queiroz, L.P. 2006. The Brazilian Caatinga: phytogeographical patterns inferred from distribution data of the Leguminosae. In: R.T. Pennington, G.P. Lewis \& J.A. Ratter (eds.). Neotropical savannas and dry forests: diversity, biogeography and conservation. CRC Press, Boca Raton, pp. 121-157.

\section{Lista de exsicatas}

Alencar, M.E. 264 (1.1); Araújo, F.S. 1593 (1.1); Arbo, M.M. 7685 (10.1); Assis, J.S. 152 (1.1); Atkins, S. 5583 (7.1); Atkinson, R. 2486 (4.1); Bandeira, F.P. 128, 168, 243 (4.1); Barros, R. s.n. (HUEFS67187) (1.1); Bastos, B.C. 413 (6.1); Bautista, H.P. 444 (4.1), 934 (7.1), 3023 (6.14), 3225 (2.1), 3422 (6.14); Belém, R.P. 1188 (10.1); Cardoso, D.B.O.S. 153 (6.16), 404 (6.14), 477 (6.16), 526 (6.1), 589 (10.1), 656 (6.14), 969
Queiroz, L.P., Conceição, A.A. \& Giulietti, A.M. 2006. Nordeste Semi-árido: caracterização geral e lista das fanerógamas. In: A.M. Giulietti, A. Conceição \& L.P. Queiroz (eds.). Diversidade e caracterização das fanerógamas do Semi-árido brasileiro. Instituto do Milênio do Semiárido e Associação Plantas do Nordeste, Recife, v.1, pp. 40-41.

Radford, A.E., Dickson, W.C., Massey, J.R. \& Bell, C.R. 1974. Vascular plant systematics. Harper \& Row, New York.

Raj, B. 1961. Pollen morphological studies in the Acanthaceae. Grana Palynologica 3: 3-108.

Rambo, B. 1964. Acanthaceae riograndenses. Iheringia 12: 1-35.

Scotland, R.W. \& Vollesen, K. 2000. Classification of Acanthaceae. Kew Bulletin 55: 513-589.

Sobrinho, J.G.C. \& Queiroz, L.P. 2005. Composição florística de um fragmento de Mata Atlântica na Serra da Jibóia, Santa Terezinha, Bahia, Brasil. Sitientibus, série Ciências Biológicas 5: 20-28.

Velloso, A.L., Sampaio, E.V.S.B., Giulietti, A.M., Barbosa, M.R.V., Castro, A.A.J.F., Queiroz, L.P., Fernandes, A., Oren, D.C., Cestaro, L.A., Carvalho, A.J.E., Pareyn, F.G.C., Silva, F.B.R., Miranda, E.E., Keel, S. \& Gondim, R.S. 2002. Ecorregiões propostas para o Bioma Caatinga. Associação Plantas do Nordeste, Recife.

Vogel, S., Machado, I.C. \& Lopes, A.V. 2004. Harpochilus neesianus and other novel cases of Chiropterophily in neotropical Acanthaceae. Taxon 53: 55-60.

Wasshausen, D.C. \& Smith L.B. 1969. Acantáceas. In: R. Reitz (ed.). Flora ilustrada catarinense. Herbário Barbosa Rodrigues, Itajaí.

Wasshausen, D.C. \& Wood, J.R.I. 2003. Notes on the genus Justicia in Bolivia. Kew Bulletin 58: 769-831.

Wasshausen, D.C. \& Wood, J.R.I. 2004. Acanthaceae of Bolivia. Contributions from the United States National Herbarium 49: 1-152.

Wasshausen, D.C. 1992. Three new species of Justicia (Acanthaceae) from Brazil. Proccedings of the Biological. Society of Washington 105: 664-673.

Wasshausen, D.C. 2004. Acanthaceae. In: N. Smith, S.A. Mori, A. Henderson, D.W. Stevenson \& S.V. Heald (eds.). Flowering plants of the Neotropics. Princeton University Press, Princeton, pp. 3-7.

(6.1), 1196 (4.1), 1430 (8.1), 1480 (9.1), 1907 (8.1); Carneiro-Torres, D.S. 498 (4.1); Carvalho, A.M. 573 (6.12), 993 (6.14), 1777 (4.1), 3024 (10.1), 3931 (4.1), 6418 (7.1); Carvalho, C.A.L. 70 (6.10); Carvalho, P.D. 12 (6.1), 119 (4.1); Carvalho-Sobrinho, J. 560 (4.1); Castro, R.M. 1279 (4.1); Cavalcanti, G. 63 (4.1); Colaço, M. 18, 130 (4.1); Conceição, A.A. 464 (2.1), 1137 (10.1), 1847 (7.1), 1924 (3.1), 1961 (6.17), 1963 (6.16), 1995 (6.1), $2130(6.17), 2310(1.1), 2312,2380$ (6.11), 2421 (6.6); Conceição, A.S. 480 (7.1); Correia, 
C. 106 (6.15); Côrtes, A.L.A. 01, 02 (4.1), 17 (8.1), 18 (6.1), $30(3.1), 31$ (9.1), 32 (6.10), $36(8.1), 60(6.12)$, 61 (4.1), 67 (10.1), $74(6.16), 75(6.5), 76(6.1), 77$ (6.2), 78 (7.1), 83 (7.1), 85 (10.1), 87 (7.1), 89 (6.3), 91 (6.15), 95 (1.1), 96 (6.3), 97 (1.1), 98 (6.3), 99 (6.1), 100 (6.16), 104 (1.1), 108 (10.1), $116(5.1), 117$ (6.9); Costa, A.L. s.n. (ALCB3894) (1.1); Dórea, M.C. 21 (4.1); Ferreira, M.C. 1112 (7.1), 1265 (4.1), 1276 (10.1); Ferreira, M.H.S. 20, 21 (9.1); Filho, L.C.O. 92 (10.1); Forzza, R.C. 1097 (10.1), 1197 (7.1); França, F. 1224 (6.13), 1824 (8.1), 2623 (10.1), 2777 (6.14), 3182 (6.5), 3744 (4.1), 3781 (6.6), 4063 (6.14), 4711 (7.1), 4780, 4800 (10.1); Ganev, W. $97(2.1), 166(7.1)$, 397 (2.1), 741, 749, 1192, 2814 (7.1), 3023 (10.1); Gasson, P. 6115 (1.1), 6178 (7.1); Giulietti, A.M. 1729 (4.1), 2004 (10.1), 2274 (7.1), 2978 (4.1), 3394 (6.13), 5473 (6.13), 5872 (6.1); Gonçalves, J.M. 10 (7.1), 48 (10.1); Guedes, M.L. 727 (6.14), 5441 (4.1), 11497 (7.1), 12097 (6.14); Harley, R.M. 16885 (6.16), 19750 (7.1), $19990(6.16), 19396(10.1), 20009,21175$ (10.1), 21361 (1.1), 22989 (6.14), 28478 (6.13), 36451 (10.1), 50121 (7.1), 53607 (10.1), 54047 (6.8), 54098 (7.1), 54328 (4.1), 54627 (6.16), 54865 (4.1), 54972 (6.5), 54973 (6.2), 55056 (10.1); Hatschbach, G. 42372 (10.1), 44147 (6.17), $46376(6.13), 46570$ (6.3), $47446(10.1), 55125(1.1), 56618(6.17), 56834(10.1)$, 61951 (10.1), $65078(6.17), 65144(6.3), 65990(4.1)$, 67604 (6.16), 67782 (6.16), 67794 (6.2), 75861 (7.1), 75864 (10.1), 77857 (6.3), 77868 (3.1); Jardim, J.G. 3535 (6.1), 3625 (6.7); Junqueira, M.E.R. 12 (6.13); Kameyama, C. 57 (10.1); Leal, S. 1 (4.1); Leite, K.R.B. 187 (1.1), 404 (4.1); Lobo, C.M.B. 12 (6.13), 70 (6.1); Machado, C.G. 14 (10.1); Machado, R. 152 (6.6), 245 (6.2), 250 (6.6); Melo, E. 1147 (8.1), 1184 (7.1), 1274 (6.14), 1691 (6.14), 1905, 1972 (8.1), 2103 (8.1), 2699 (4.1), 3187 (10.1), 3326, $3536(7.1), 3539(2.1)$, 3548 (10.1), 3641 (10.1), 3792 (4.1), 3958 (6.13),
4211 (6.13), 4634 (8.1), 4637 (9.1), 4265 (4.1), 4625 (6.1), 4692 (6.2), 4694 (6.6), 5011 (3.1), 5157 (6.10); Miranda, A.M. 3003 (4.1); Miranda, E.B. 148 (6.14), 500 (10.1), 766 (6.3), 802 (6.2); Miranda, L.A.P. 70 (10.1); Moraes, A.O. 111 (4.1), 263 (10.1); Moraes, M.V. 195 (10.1), 619 (4.1), 657 (1.1); Mota, A.C. 5 (6.5); Nascimento, J.G.A. 43 (6.5); Noblick, L.R. 2604 (6.13), 4293 (6.1); Nonato, F.R. 855 (6.14); Novais, J.S. 22 (8.1); Nunes, T.S. 128 (7.1), 505 (4.1), 880, 947 (7.1), 1086 (4.1), 1201 (6.14); Oliveira, A.A. 164 (4.1); Oliveira, M.V.M. 702 (4.1); Oliveira, R.P. 765 (10.1); Oliveira-Filho, C.O. 127 (6.2); Orlandi, R.P. 195 (6.14), 356 (7.1), 372 (1.1); Passos, L. 5721 (7.1); Pereira-Silva, G. 8429, 8431, 9115, 9140 (10.1); Pirani, J.R. 2013 (10.1), 51339 (7.1); Queiroz, L.P. 970 (6.10), 1029 (3.1), 1377 (9.1), 1378 (8.1), 1690 (6.17), $1730(6.1), 2148(6.13), 2610(7.1), 3033(7.1)$, 3280 (10.1), 3337 (6.14), 3960 (4.1), $4575(6.1), 4637$ (4.1), 4793, 4887 (4.1), $5226(7.1), 5296(10.1), 5755$ (6.13), $5894(6.1), 7158,7172,7899,7997(4.1), 8019$, 8082 (4.1), 9608 (4.1), 9383 (10.1), 9981 (6.5), 10878 (4.1), 12791 (6.4), 12883 (2.1); Rapini, A. 1390 (10.1), 1428 (8.1); Ribas, O.S. 77857 (6.3); Ribeiro, T. 251 (10.1), 406 (6.15); Roque, N. 634 (4.1); Sant'Ana, C. 626 (4.2); Santos, A.K.A. 986 (7.1); Scardino, L.S.F. 716 (8.1); Sessegolo, G.C. 167 (4.1); Silva, F.H.M. 375 (4.1); Silva, M. M. 278 (10.1); Silva, S.B. 211 (1.1); Silva, T.R.S. 99 (10.1); Silva-Castro, M.M. 619 (10.1); Simon, J.L. 1190 (6.16); Sobral, M. 7572 (6.14); Socorro, M. 153 (6.6); Souza, E.R. 133 (7.1), 198 (5.1), 288 (6.3), 289 (2.1), 292 (10.1); Souza, M.V. 5207 (10.1); Souza-Silva, R.F. 32 (6.14); Stannard, B. 51873 (10.1), 51890 (7.1), 51927 (10.1); Thomas, W.W. 10676 (4.2), 13602 (5.1); Vaillant, P. 58 (7.1); Van den Berg, C. 983 (6.1); Webster, G.L. 25830 (8.1); Woodyer, E. 2230 (10.1). 